\title{
ASO3-78ET 13105
}

MASTER

THE UTILIZATION OF SHALE OIL AS A FEEDSTOCK FOR

STEAM PYROLYSIS AND PETROCHEMICAL INTERMEDIATE PRODUCTION

$$
\text { DOE/ET/13105--TI }
$$

QUARTERLY TECHNICAL PROGRESS REPORT

FOR THE PERIOD JUNE - AUGUST 1978

PHILIP F. DICKSON AND VICTOR F. YESAVAGE

CHEMICAL AND PETROLEUM-REFINING ENGINEERING

COLORADO SCHOOL OF MINES

GOLDEN, COLORADO 80401

DATE PUBLISHED - SEPTEMBER 5, 1978

PREPARED FOR

U.S. ENERGY RESEARCH AND DEVELOPMENT ADMINISTRATION

LARAMIE ENERGY RESEARCH CENTER

LARAMIE, WYOMING 82071

UNDER CONTRACT NO. E(29-2)-3726

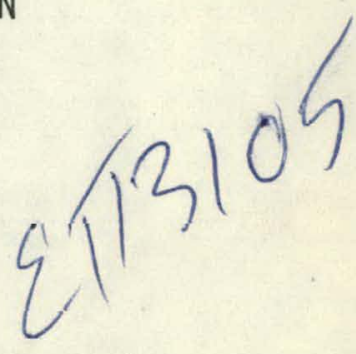

REDESIGNATED AS

EY-76-S-04-3726
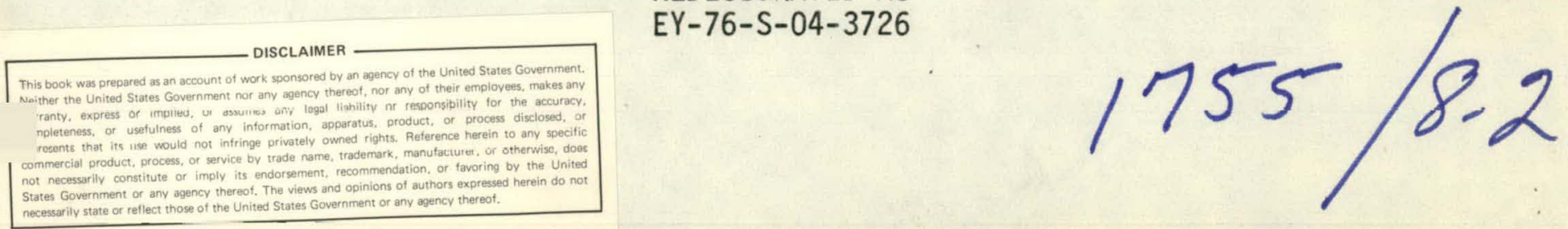


\section{DISCLAIMER}

This report was prepared as an account of work sponsored by an agency of the United States Government. Neither the United States Government nor any agency Thereof, nor any of their employees, makes any warranty, express or implied, or assumes any legal liability or responsibility for the accuracy, completeness, or usefulness of any information, apparatus, product, or process disclosed, or represents that its use would not infringe privately owned rights. Reference herein to any specific commercial product, process, or service by trade name, trademark, manufacturer, or otherwise does not necessarily constitute or imply its endorsement, recommendation, or favoring by the United States Government or any agency thereof. The views and opinions of authors expressed herein do not necessarily state or reflect those of the United States Government or any agency thereof. 


\section{DISCLAIMER}

Portions of this document may be illegible in electronic image products. Images are produced from the best available original document. 
ABSTRACT

During the past quarter, 25 runs were made on a number of hydrotreated samples including a mildly hydrotreated simulated in-situ $(1.35 \% \mathrm{~N})$ and two moderately hydrotreated Tosco II $(0.82 \% \mathrm{~N}$ and $1.55 \% \mathrm{~N})$ distillates. The results are, in general, consistant with previous results which indicated an increase in olefins yield as the severity of hydrogenation increased. The olefins yields for the simulated in-situ oil were greater than those for the Tosco II oil for oil hydrogenated to comparable severities. The moderately hydrogenated Tosco II oil exhibited gasification tendencies at severe pyrolysis conditions, similar to the severely hydrogenated Tosco II oil.

Correlational efforts were continued in using the propylene yield versus severity factor, and the yields of all major gas components versus proplyene to ethylene ratio as a means of correlating pyrolysis yields. The efforts were extended to the hydrogenated simulated in-situ and Tosco II distillates. 


\section{Objective and Scope of Work}

Petrochemical utilization of oil shale has long been considered, but only recently has the volume of petrochemical demand reached a level where it can affect the overall economics of utilization of liquid hydrocarbons. Production of light olefin and aromatic intermediates by pyrolysis appears an attractive method to avoid the hydrogenation catalyst poisoning effects of nitrogen. The program investigates five samples on each of the two crude shale oils: (1) the "whole" crude shale oil, (2) a vacuum distillate of the crude shale oil, (3) a mild hydrogenation of the distillate, (4) a deeper hydrogenation of the distillate, and (5) a severe hydrogenation of the distillate to produce a synthetic crude shale oil with essentially zero nitrogen content.

The research is divided into five major tasks:

Task 1. Equipment design and construction, samples of the two types of crude oil obtained and prepared for testing and hydrogenation

Task 2. Hydrogenation of Samples

Task 3. A. Experimental Measurements on Non-Hydrogenated Samples

B. Experimental Measurements on Hydrogenated Samples

Task 4. Analyses and Measurements on Feedstocks and Products

Task 5. Data Correlation

Task 1: Equipment Design and Construction

No modifications to the experimental equipment were made this quarter. Task 2: Hydrogenation of Samples

Hydrogenation of Tosco II and simulated in-situ distillates were previously completed and the results were discussed in an earlier Progress Report. 
Task 3: Experimental Measurements on Non-Hydrogenated and Hydrogenated Samples

Twenty-five experimental runs were completed during this quarter:

5 on Sample 6201 , the mild severity hydrogenated simulated in-situ oil $(1.35 \% N)=$ Run $30-34$

9 on Sample 6206, the medium severity hydrogenated Tosco oil $(0.82 \% \mathrm{~N})=$ Run $35-43$

9 on Sample 6205, the mild severity hydrogenated Tosco oil $(1.55 \% \mathrm{~N})=$ Run 44-52

1 on n-octane to check reproducibility with other investigators

1 on a high severity hydrogenated sample oil from the Paraho retort process

Detailed experimental results for each run are included in the appendix.

Table 1 is a compilation of selected product results of experimental runs of Sample 6201. Runs were made at low residence time for temperatures of $1308,1407,1497$, and $1546 \mathrm{~F}$. Increasing temperature at low residence time resulted: in increased ethylene production. Propylene and butylene production increased, then decreased. Runs were made at medium residence time for temperatures of 1305,1412 , and $1507 \mathrm{~F}$. 0lefin production followed expected trends. A run was made at high residence time at $1409 \mathrm{~F}$. No gasification tendencies were observed with this mild severity hydrogenated sample.

Results of experimental runs on Sample 6206 are summarized in Table 2. For this medium severity hydrogenated Tosco vacuum distillate; runs were made at low residence time for temperatures of $1301,1407,1508$, and $1548 \mathrm{~F}$. Ethylene production increased with temperature, but dropped at the highest temperature. Runs were made at medium residence time for temperatures of 1315,1402 , and $1511 \mathrm{~F}$, resulting in expected trends in product yields. Two additional runs were made, one at high residence time and $1411 \mathrm{~F}$, and 
one at low steam-0il mass ratio and $1579 \mathrm{~F}$. With this Tosco sample, runs 38,42 , and 43 at high pyrolysis severity, gasification tendencies (high hydrogen and carbon oxide production) were observed.

The last hydrogenated vacuum distillate studies was sample 6205, the mild severity Tosco oil. Experimental results for selected products are summarized in Table 3 . Runs were made at low and medium residence time for approximate temperatures of 1300,1400 , and $1500 \mathrm{~F}$. Additional runs at high residence time and $1400 \mathrm{~F}$, and at low steam-oil rat10, high residence time, $1500 \mathrm{~F}$ were also completed. Ethylene production increased with temperature, and propylene ad butene yields followed expected trends. For sample 6205, no evidence of gasfication in the operating range studied was observed.

A run was made with n-octane feedstock to check the consistancy of experimental results of the CSM pyrolysis system with the results of other investigators. The results shown in Table 4 are compared with published results from investigations at the University of Pittsburgh (1). The product yields compare closely for all components except ethylene and propylene. The CSM light olefin yield is higher than the Pitt yields. The difference is due to utilization of steam as a carrier medium in the CSM experiment whereas Pitt apparently did not. Steam has been reported by other investigators to be a promoter of light olefin production in pyrolysis.

A high severity hydrogenated $(0.04 \% \mathrm{~N})$ sample of 011 from a Paraho retort has been obtained. The quantity of Paraho sample is much larger than the hydrogenated Tosco and NTU vacuum distillates. Plans call for investi-. gating the pyrolysis characteristics of the Paraho oil to check for gasification tendencies. One run has been made at low residence time at $1411 \mathrm{~F}$, which produced: 


$$
\begin{aligned}
& \text { wt.\% of feed } \\
& c_{2}=27.4 \\
& c_{3}=15.2 \quad 54.0 \\
& c_{4}=11.4
\end{aligned}
$$

In order to determine the effect of the feedstock type on pyrolysis yields, the results of 89 pyrolysis experimental runs on whole oil, vacuum distillate, and mild, medium, and high severity hydrogenated vacuum distillates of Tosco and simulated in-situ shale oils have been represented as a function of a previously utilized pyrolysis severity factor defined as:

$$
\text { where } \quad \begin{aligned}
& S=T \cdot \theta^{0.06} R^{0.05} \\
& S=\text { severity function } \\
& T=\text { temperature, }{ }^{\circ} \mathrm{F} \\
& \theta=\text { residence time, sec } \\
& R=\text { steam to hydrocarbon mass ratio }
\end{aligned}
$$

Two series of figures show the relationship between feedstock and yield of light olefin products. The total olefin, ethylene, propylene, and butene production for each individual oil is shown in Figures $1-10$. This product information is then represented in Figures $11-18$ to show production of each olefin for all samples of each shale oil. The general trends in Figures 11 - 18 are apparent; for both the Tosco and simulated in-situ samples, as severity of hydrogenation increases, the yield of light olefins increases with the exception of the high severity pyrolysis of the most severly hydrogenated samples, where the significant drop in olefin production is the results of sample gasification. Specific details of olefin yields can be seen in the individual figures.

Although the severity factor used above is not the optimum, it allows us to observe the effect of feedstock type on pyrolysis yields. In Task 5, we discuss our ongoing correlation efforts aimed at determining an optimum 
pyrolysis severity factor.

Key to Figure $1-10$

$\begin{array}{lll}\text { top line } & x & \text { total olefin } \\ + & \text { ethylene } \\ & \Delta & \text { propylene } \\ \text { bottom line } & 0 & \text { butenes }\end{array}$

Key to Figure $11-18$

top line

bottom line a

0

$\Delta$

$+$

$x$ high severity hydrogenated vacuum distillate

medium severity hydrogenated vacuum distillate

low severity hydrogenated vacuum distillate

vacuum distillate

whole oil

NTU = Laramie simulated in-situ shale oil 
Table 1 - Summary of Pyrolysis Results for a Hydrogenated (1.35\% N) Simulated In Situ Vacuum Distillate

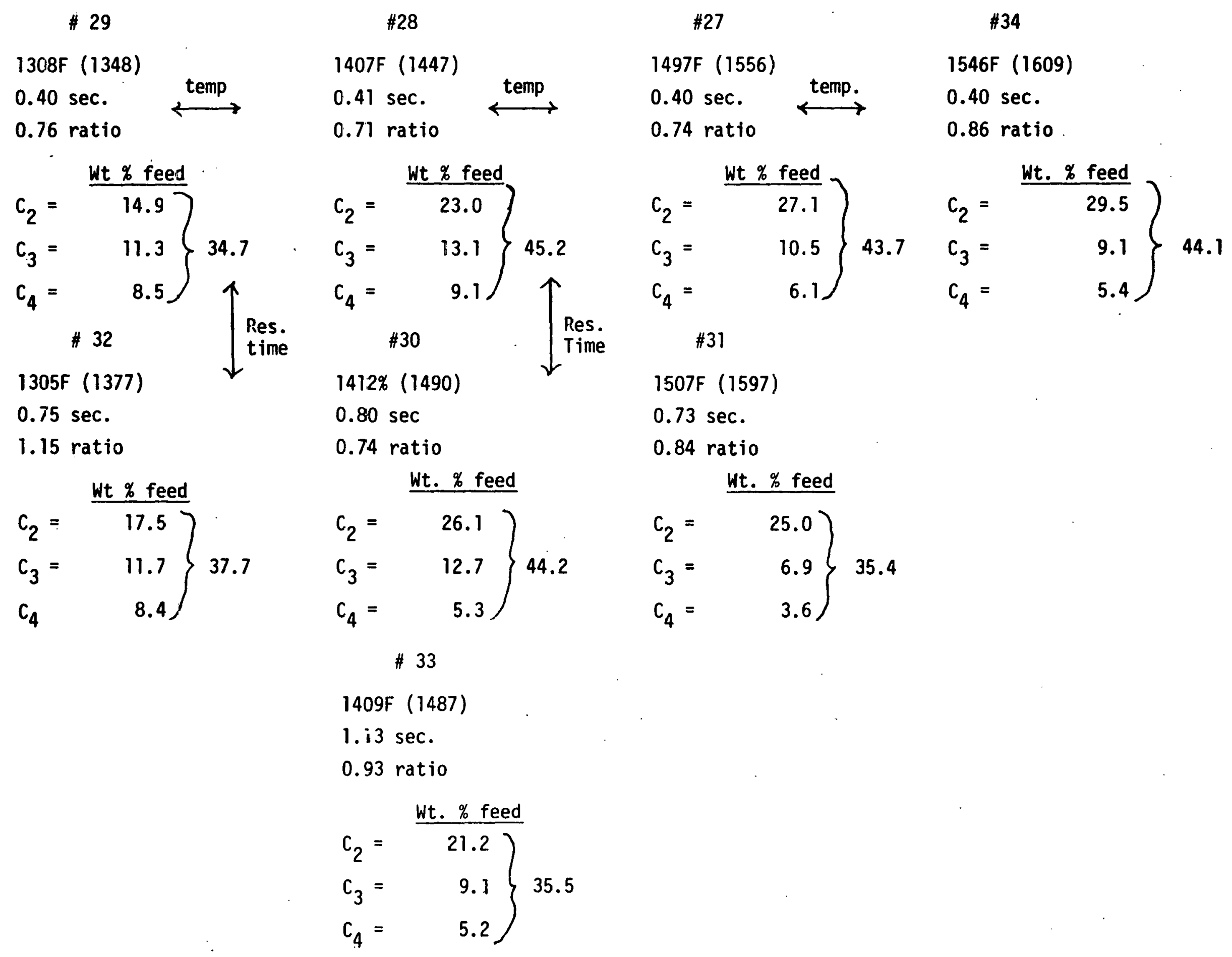


Table 2 Summary of Pyrolysis Results for a Hydrogenated (0.82\% N)

TOSCO Vacuum Distillate

\#37

$1301 F(1336)$

$0: 40 \mathrm{sec}$ :

0.83 ratio

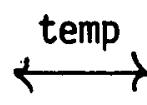

Wt $\%$ feed

$c_{2}=13.8$

$\mathrm{C}_{3}=$

$9.3\} 29.6$

$\mathrm{C}_{4}=$

$6.6)$

\#40

$1315 F(1354)$

0.73 sec.

0.85 ratio

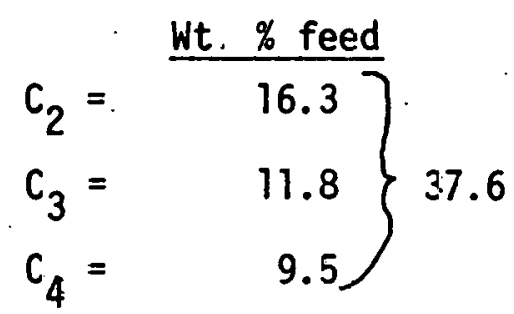

\# 35

1407F (1463)

$0.43 \mathrm{sec}$

0.67 ratio

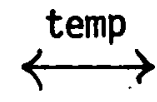

$c_{2}=$
$c_{3}=$
$c_{4}=$

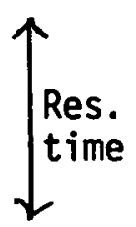

Wt $\%$ feed

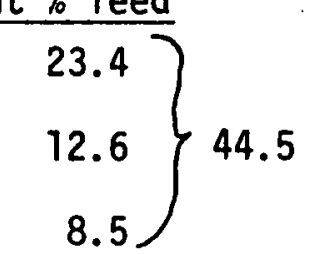

\# 39

$1402 \mathrm{~F}(1467)$

$0.84 \mathrm{sec}$.

0.70 ratio

$c_{2}=$
$c_{3}=$
$c_{4}=$

Wt \% feed

$\left.\begin{array}{c}21.9 \\ 11.3 \\ 8.2\end{array}\right\}$

\#41

$1417 F(1489)$

$1.03 \mathrm{sec}$

0.78 ratio

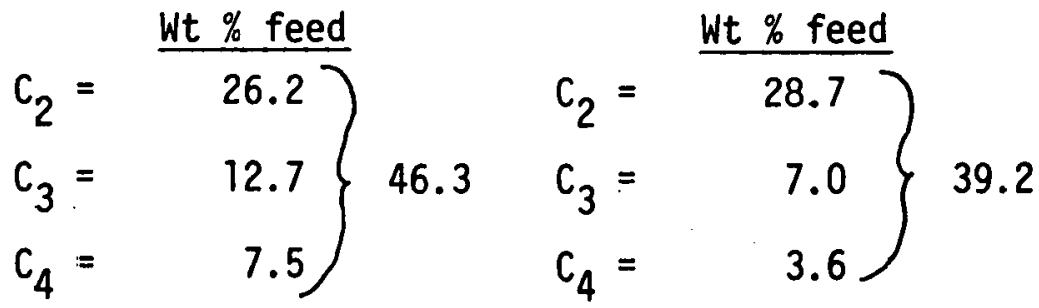

$\# 43$

$1508 \mathrm{~F}(1576) \cdot 1548 \mathrm{~F}$ (1603)

$0.42 \mathrm{sec}$ temp $0.44 \mathrm{sec}$

0.69 ratio

0.69 ratio

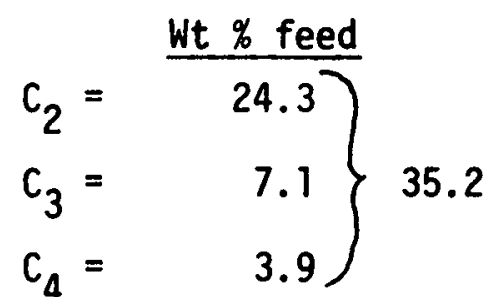


Table 3 Summary of Pyrolysis Results for a Hydrogenated (1.55 \%N) TOSCO Vacuum Distillate

\#46

1299F (1335)

$0.40 \mathrm{sec}$

0.77 ratio

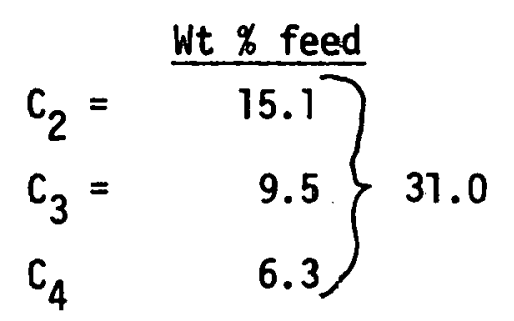

\#50

$1298 \mathrm{~F}(1363)$

$0.85 \mathrm{sec}$

0.73 ratio

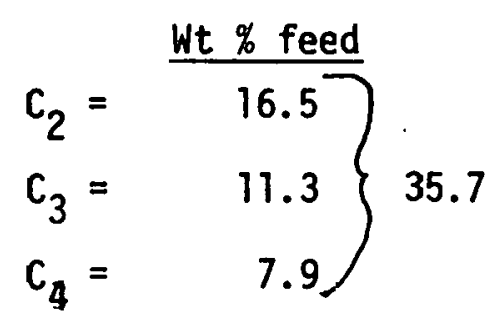

\#45

$1400 \mathrm{~F}$ (1464)

$0.39 \mathrm{sec}$

0.73 ratio

$c_{2}=$
$c_{3}=$
$c_{4}=$

Wt \% feed

个 \#49

$1400 \mathrm{~F}(1471)$

$0.77 \mathrm{sec}$

0.78 ratio

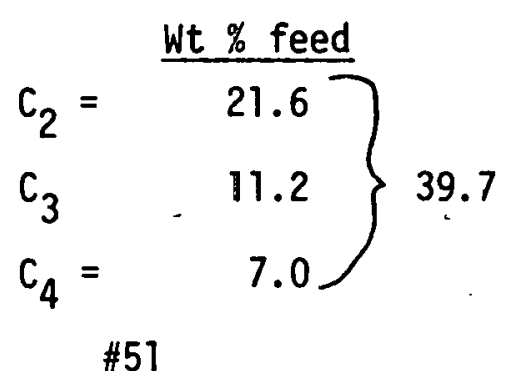

$1402 \mathrm{~F}$ (1470)

$1.18 \mathrm{sec}$

0.64 ratio

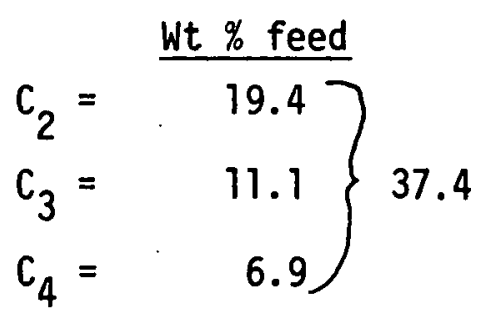

\#4

1509F (1576)

$0.40 \mathrm{sec}$

0.73 ratio

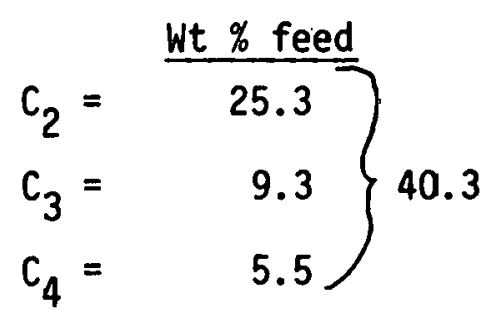

\#48

$1501 \mathrm{~F}(1588)$

$0.76 \mathrm{sec}$

0.75 ratio

$$
\left.\begin{array}{lr}
c_{2}= & \frac{\text { Wt \% feed }}{24.9} \\
c_{3}= & 7.7 \\
c_{4}= & 4.4
\end{array}\right\} 37.0
$$

1498F (1585)

$1.42 \mathrm{sec}$

0.36 ratio

$\left.\begin{array}{lr}c_{2}= & \frac{\text { Wt \% feed }}{25.2} \\ c_{3}= & 6.9 \\ c_{4}= & 3.5\end{array}\right\} 3 E .5$

\#52

1560F (1629)

$0.43 \mathrm{sec}$

0.73 ratio

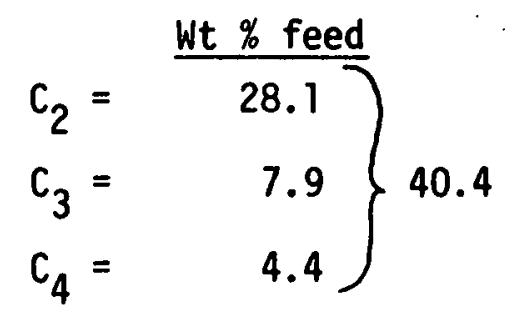


Table 4

Results of Pyrolysis of $n$-0ctane
(mole/100 mole feed)

CSM

$1.323 F$ ave

$1370 \mathrm{~F}$ max

32.0

80.9

24.8

169.7

2.1

61.2

0.7

26.5
Pitt

$\underline{1292 \mathrm{~F}}$
Pitt

$1337 \mathrm{~F}$

$\mathrm{C}_{2} \mathrm{H}_{6}$

$\mathrm{C}_{2} \mathrm{H}_{4}$

$\mathrm{C}_{3} \mathrm{H}_{8}$

$\mathrm{C}_{3} \mathrm{H}_{6}$

$\mathrm{C}_{4} \mathrm{H}_{10}$

$\mathrm{C}_{4}$ olefins

Reference:

Y. T. Shah, E. B. Stuart, and K. D. Sheth, 1976, Coke Formation during Thermal Cracking of n-Octane: I\&EC Process Des. Dev., v. 15, n.4, pp. $518-524$. 
Figure 1

NTU WHOLE
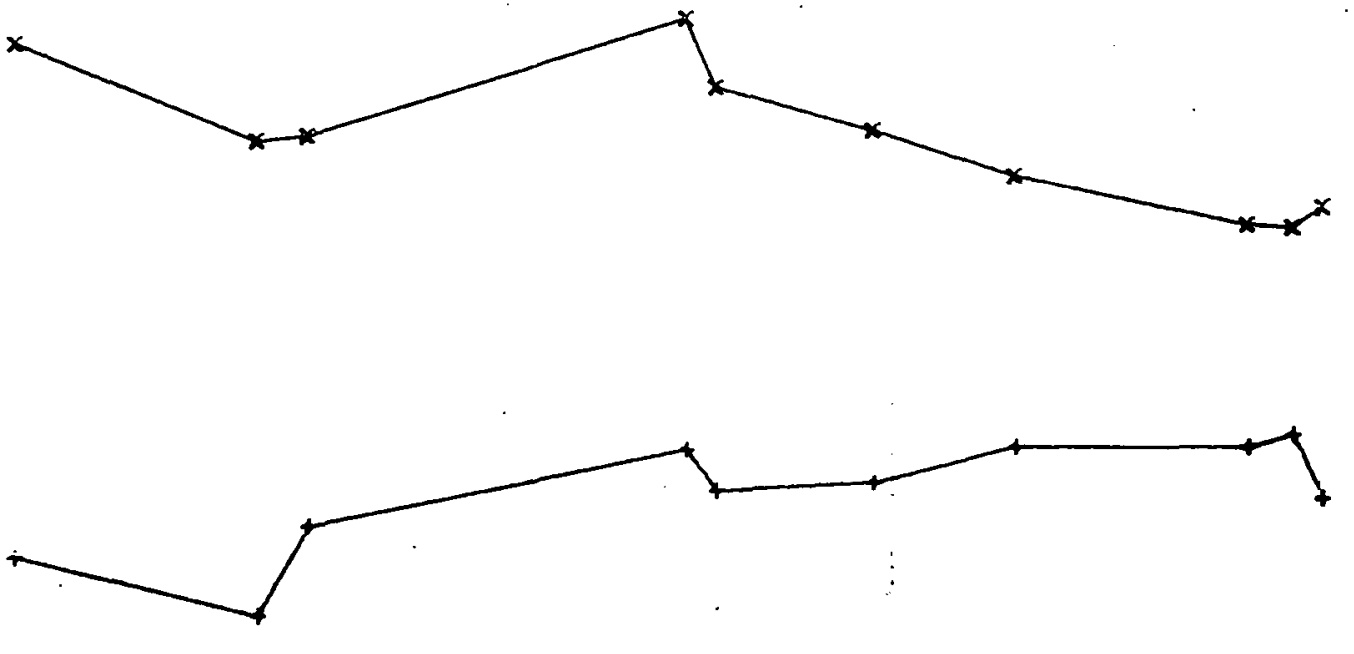

$\otimes$

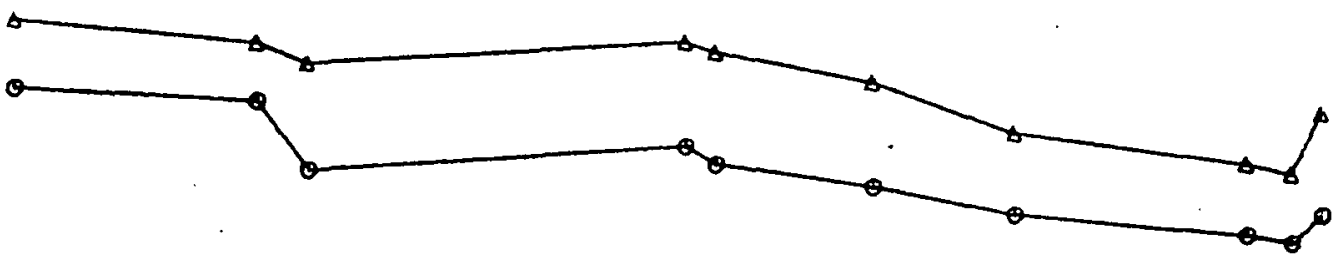

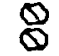

$\begin{array}{lllllllll}1200.00 & 1250.00 & 1300.00 & 1350.00 & 1400.00 & 1450.00 & 1500.00 & 1550.00 & 1600.00\end{array}$ PYROLYSIS SEVERITY 
8

ब

NTU VAC DIST

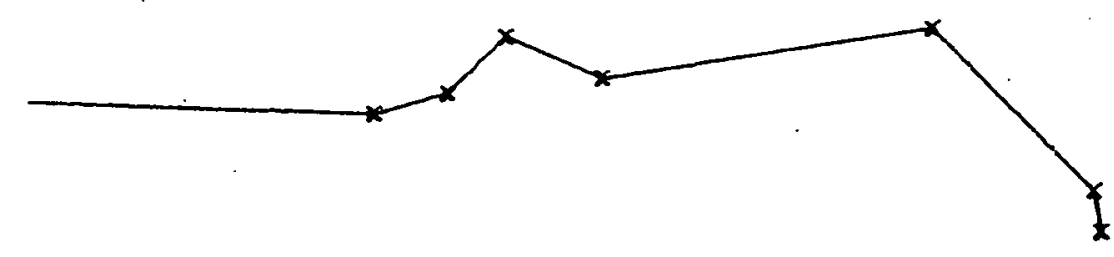

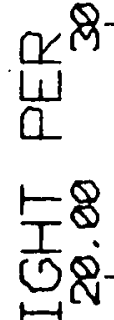

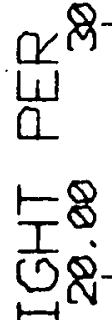

แه

L守

乬

แब

닉

$\$$

$0,200.00$

1250.00

1300.00

1350.00

1400.00

1450.00

1500.00

1550.00 


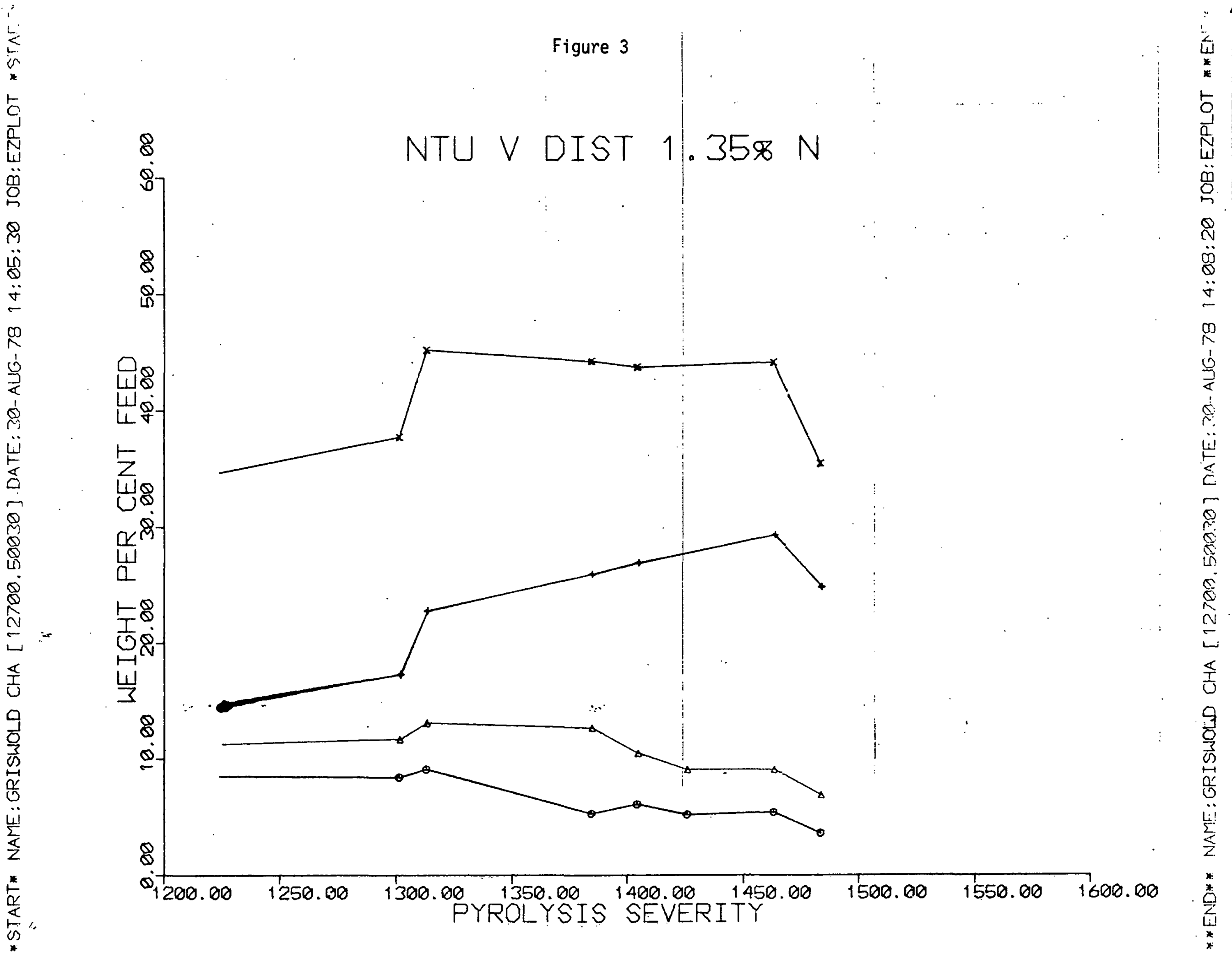


Figure 4

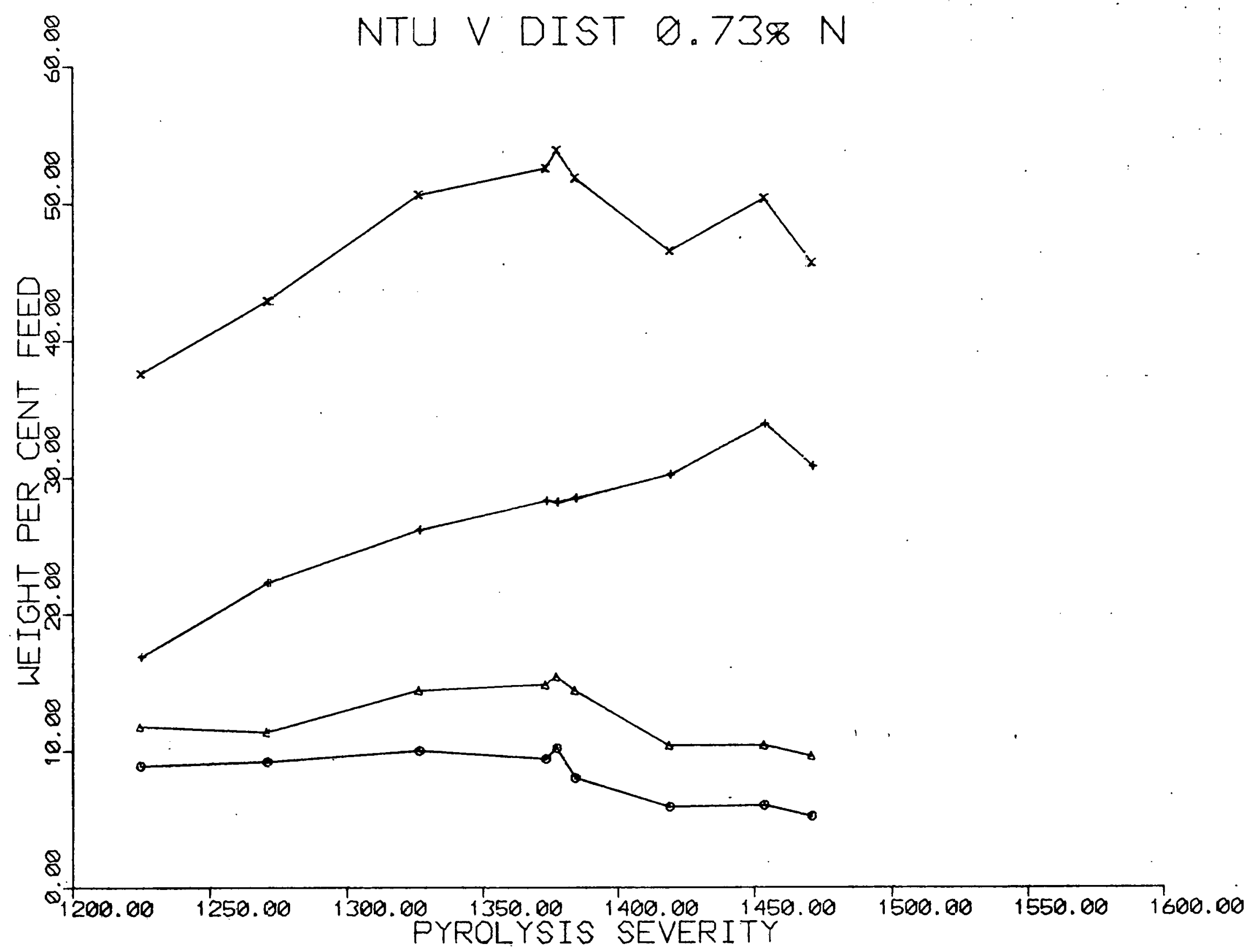

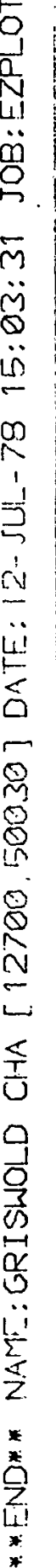




\section{NTU V DIST $0.08 \% \mathrm{~N}$}

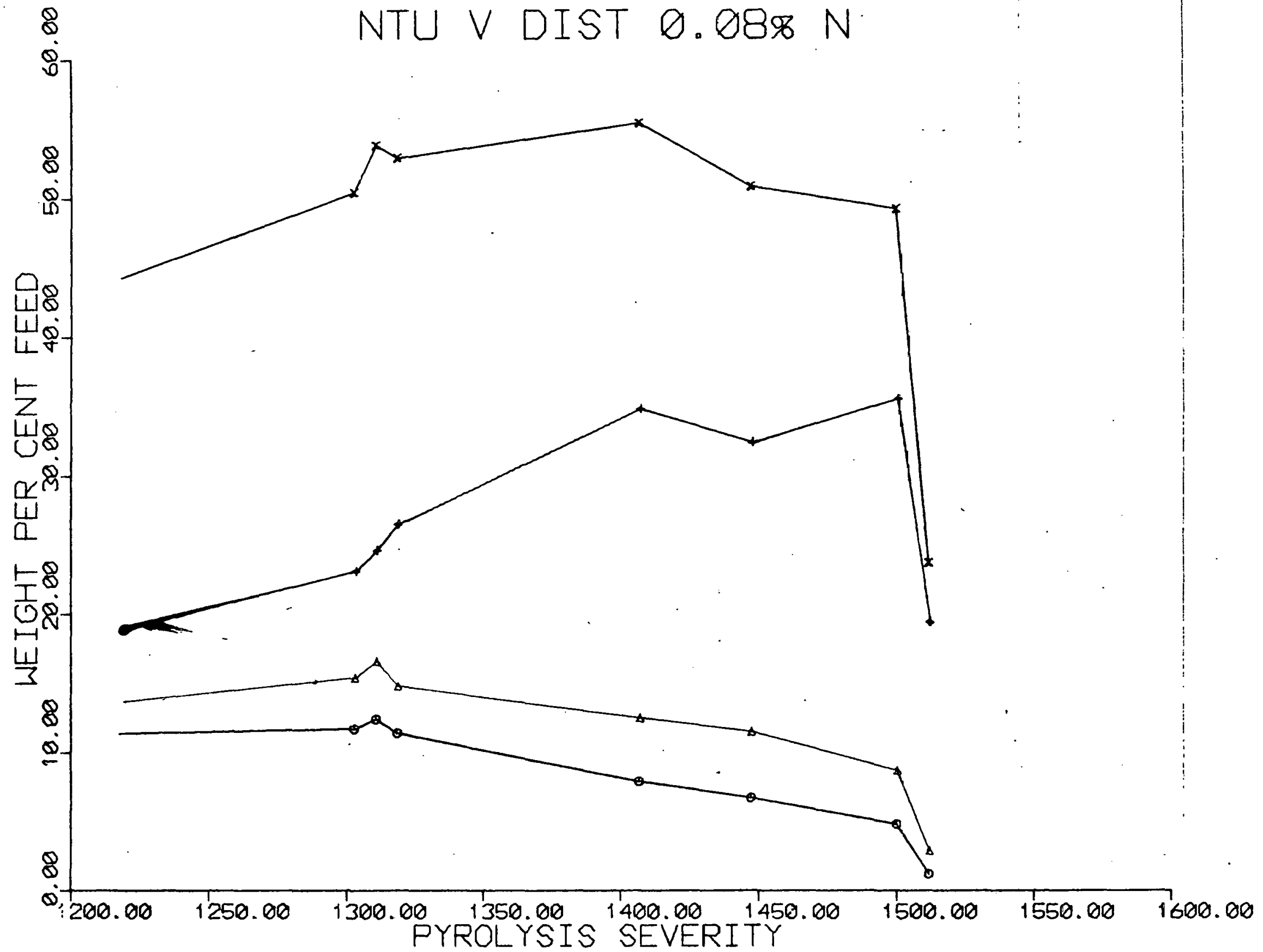


Figure 6

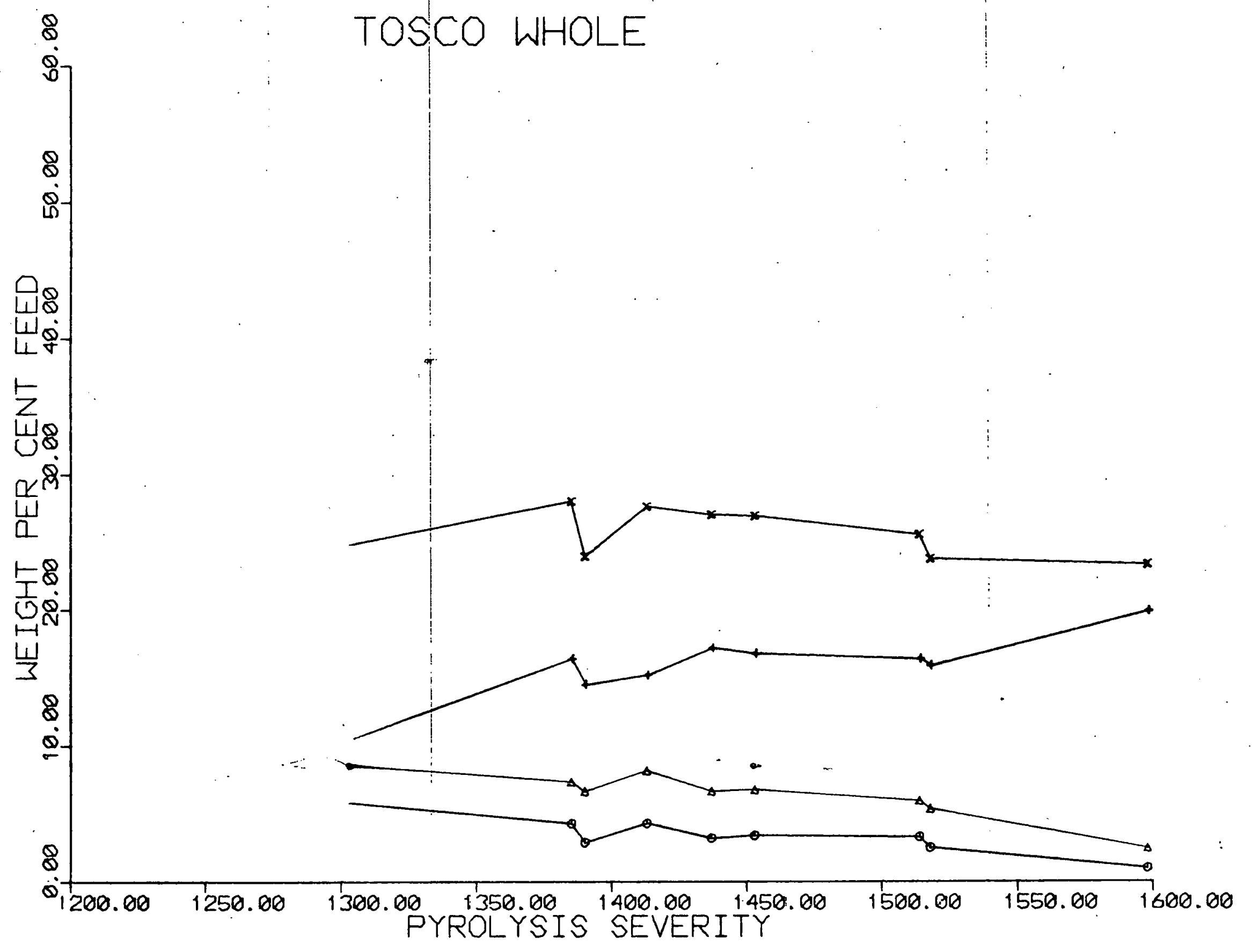


Figure 8

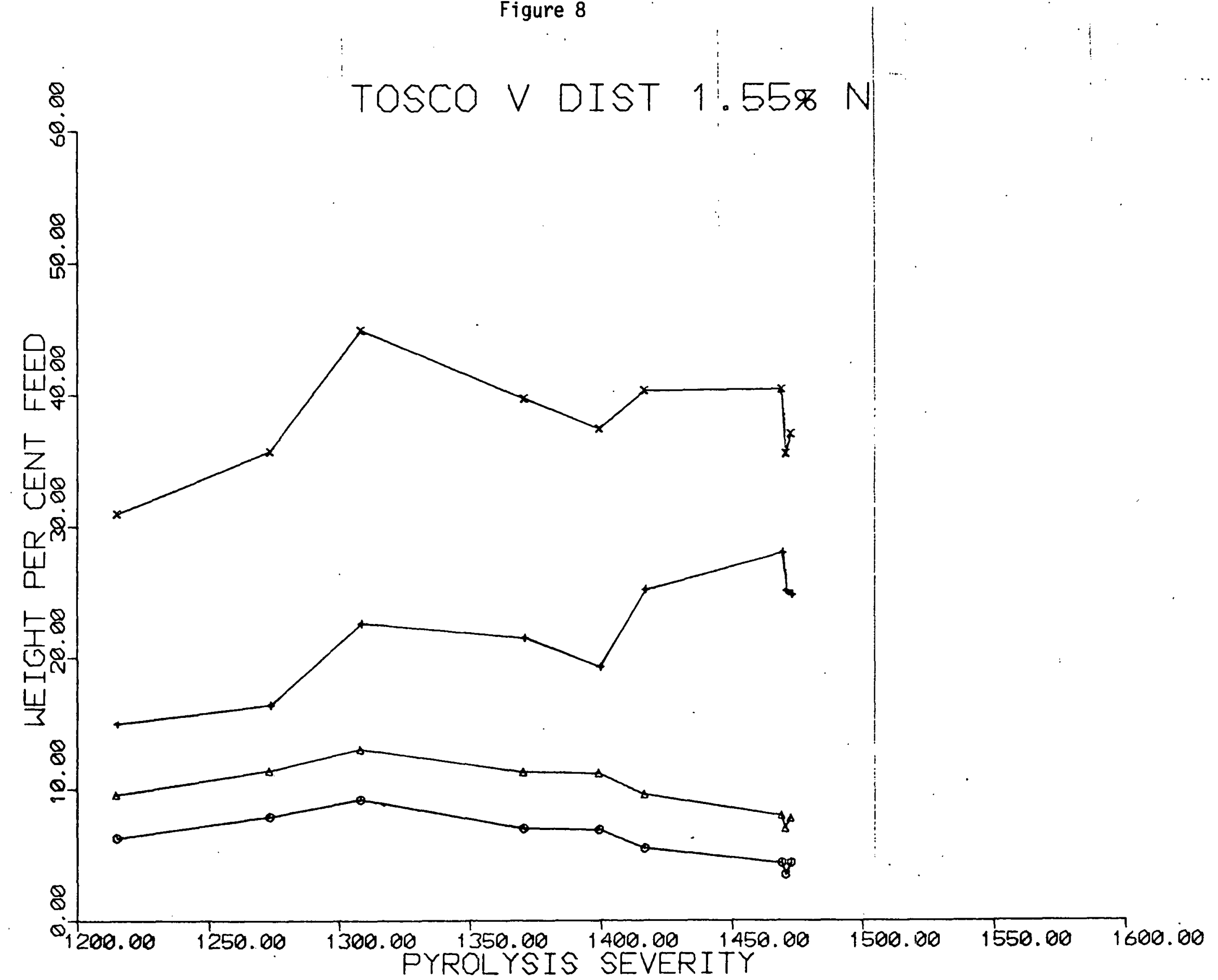


Figure 9

TOSCO V DIST $0.828 \mathrm{~N}$

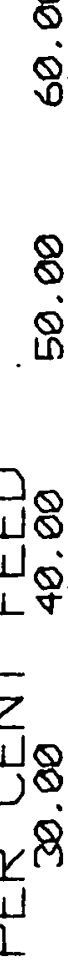

남

도용

点

岁

8

8

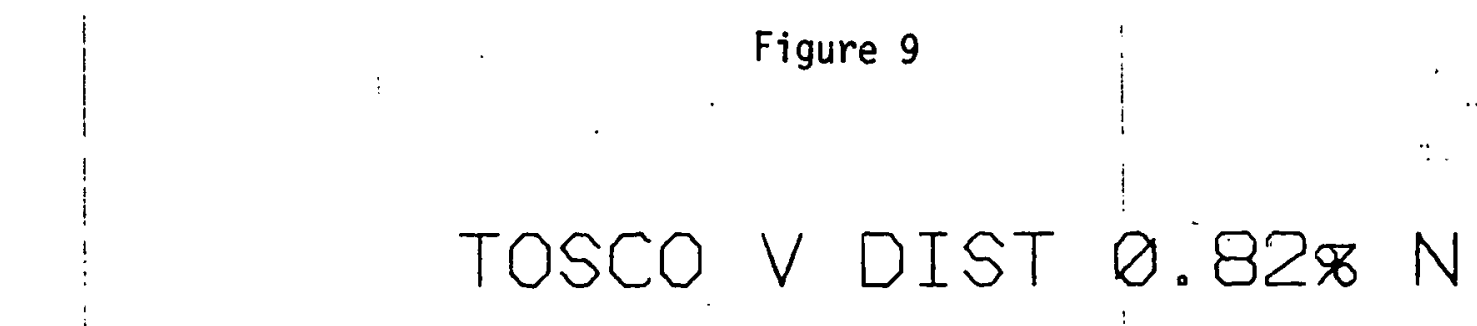

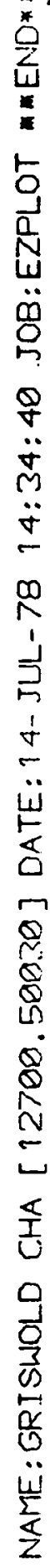

01200.00

1250.00

1300.00 
Figure 10

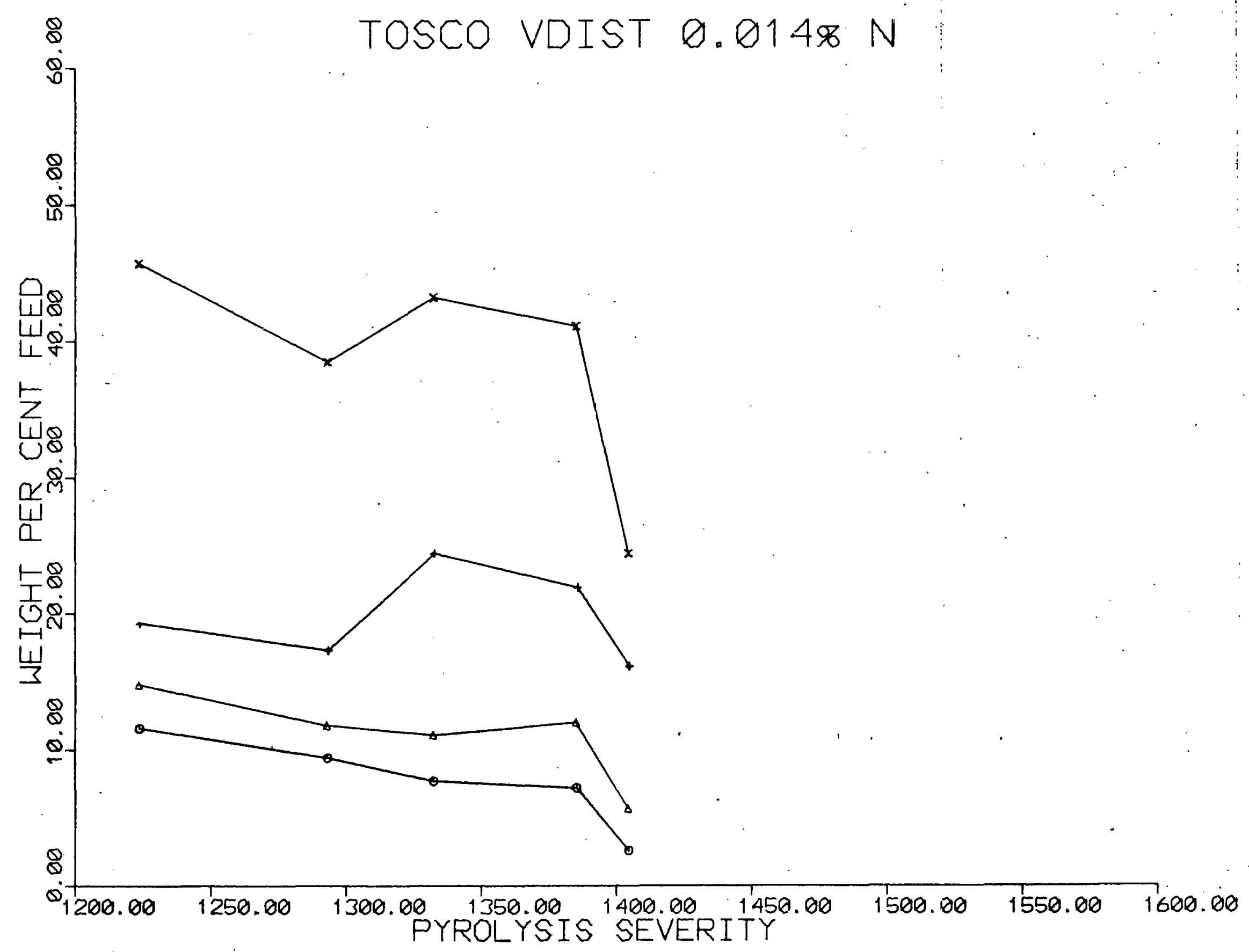




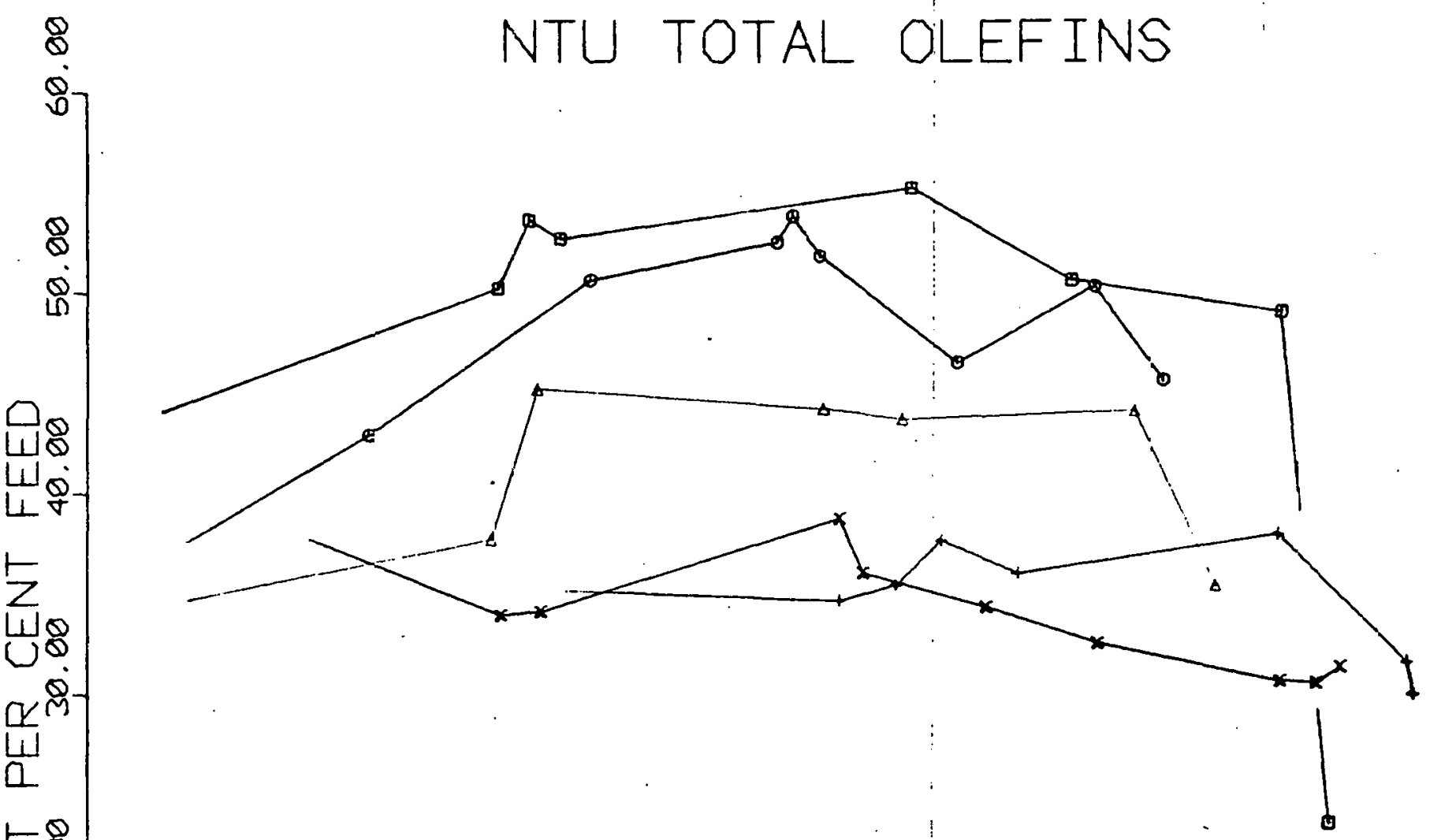




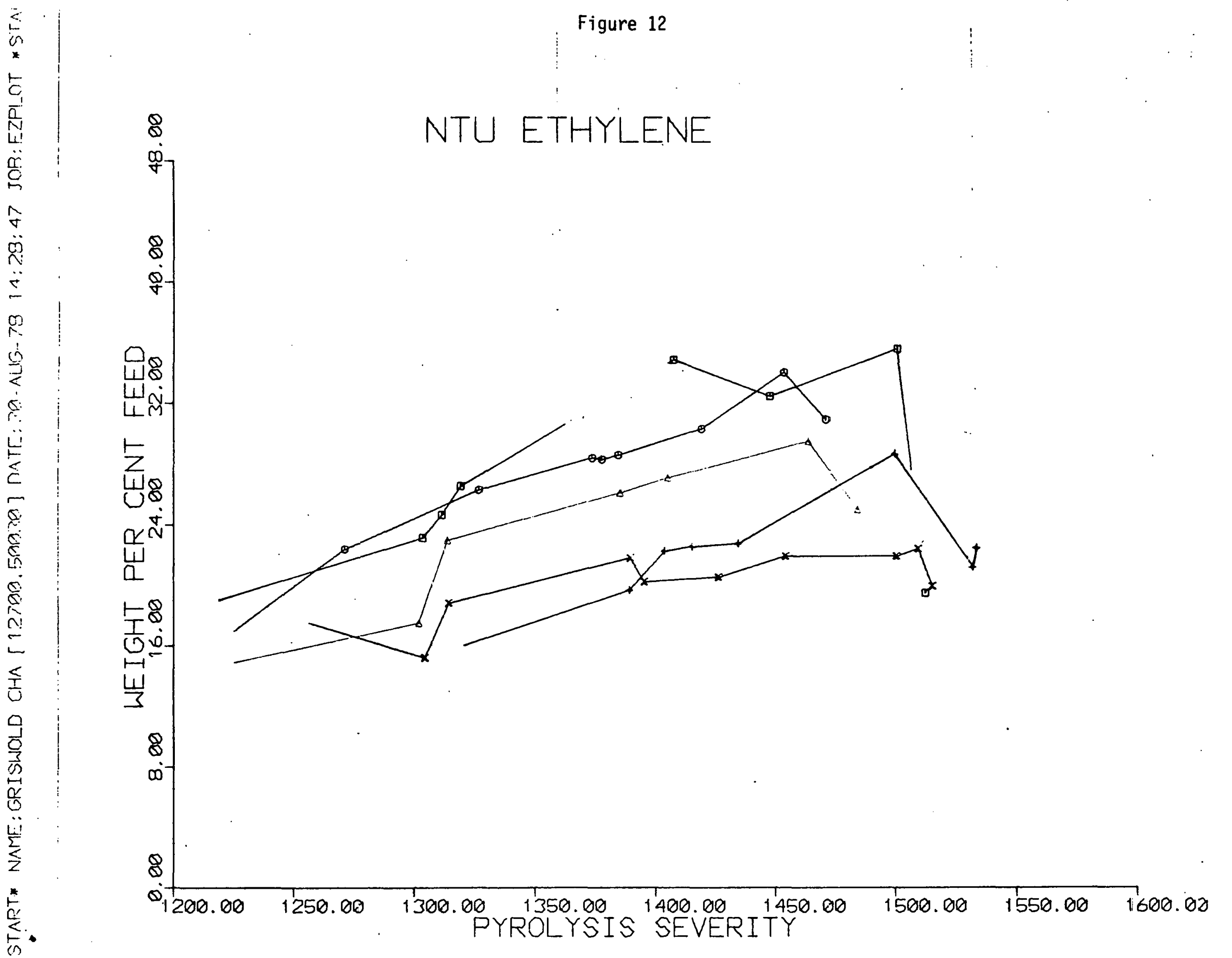




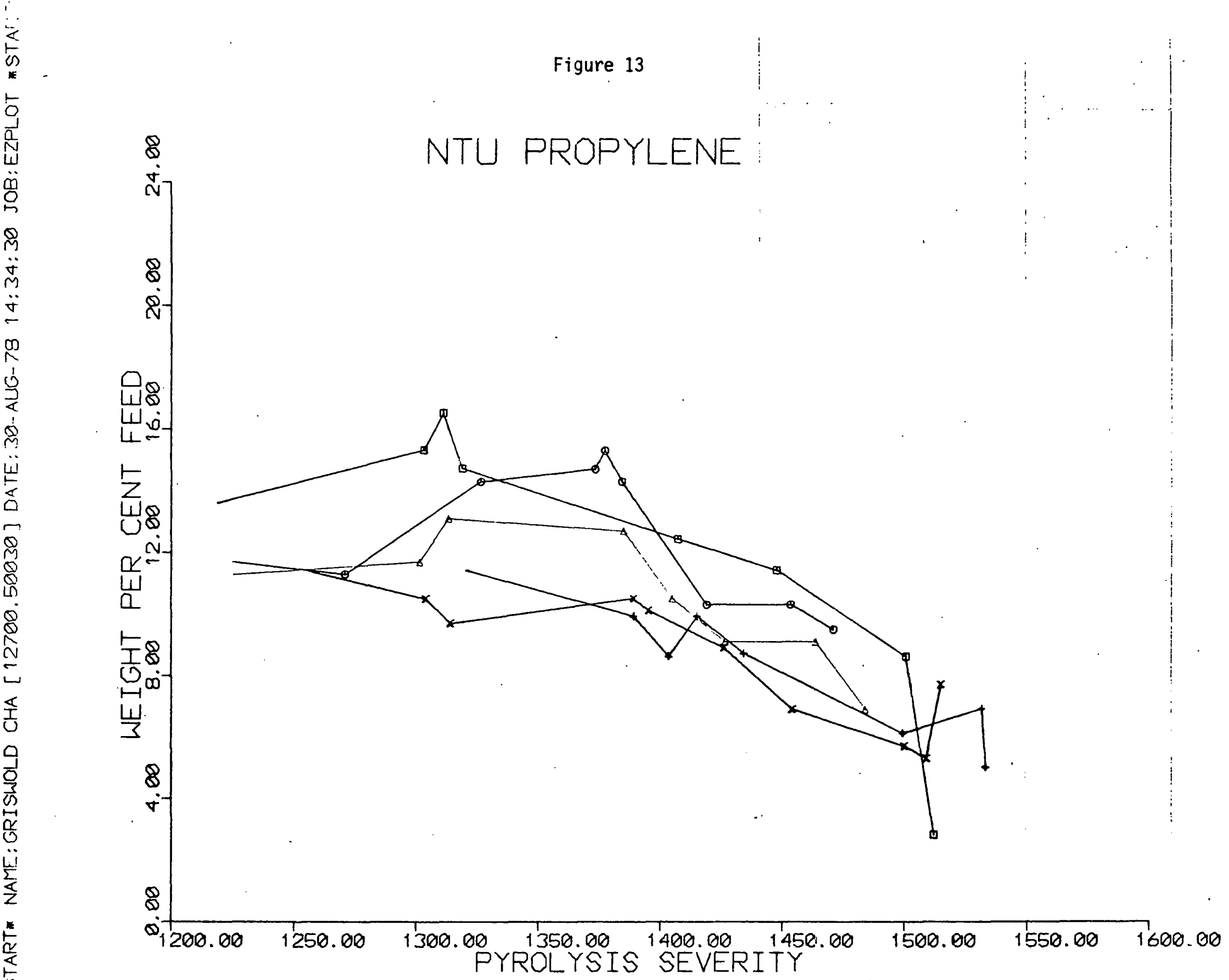




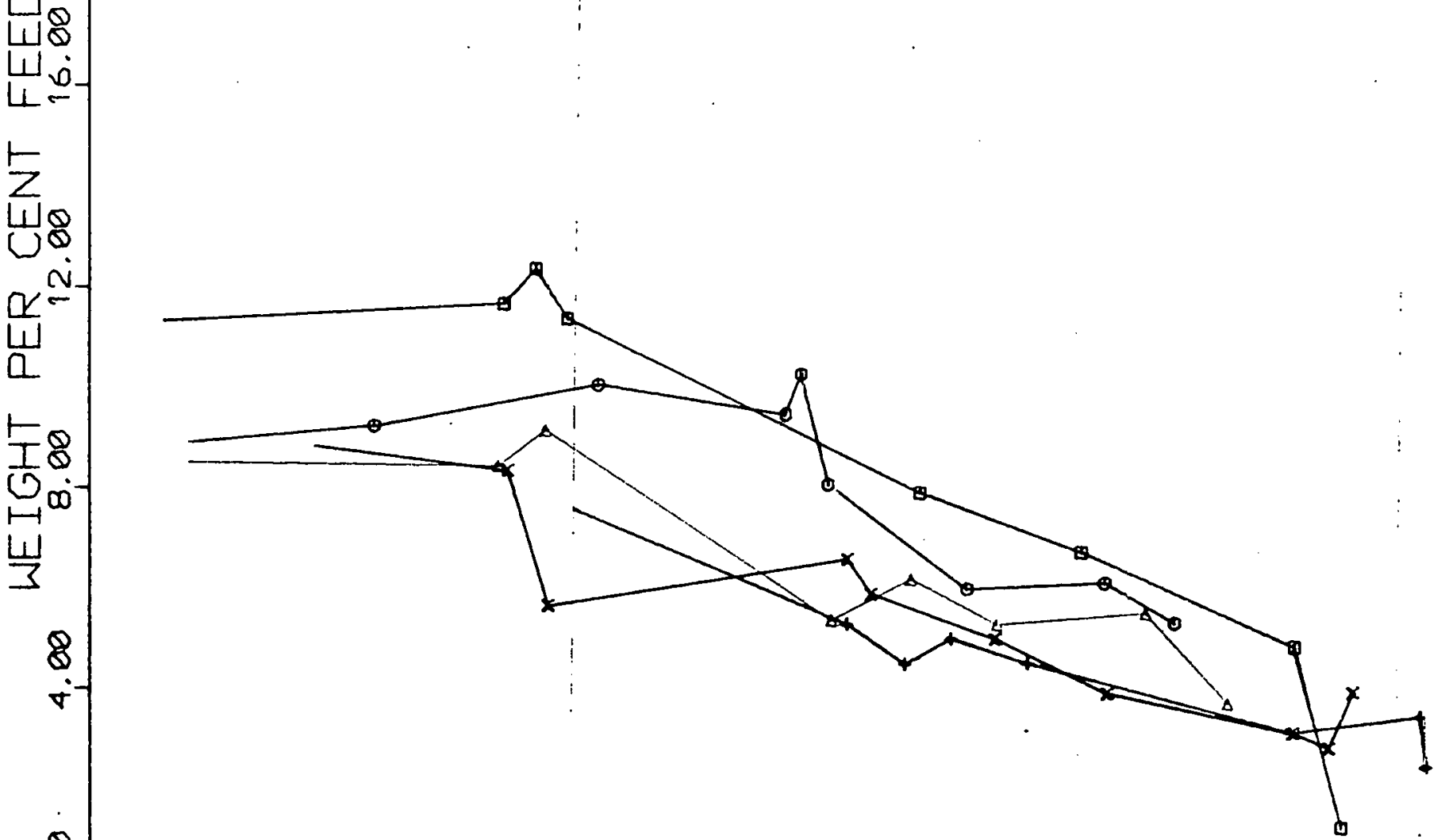

$\&$ 
Figure 15

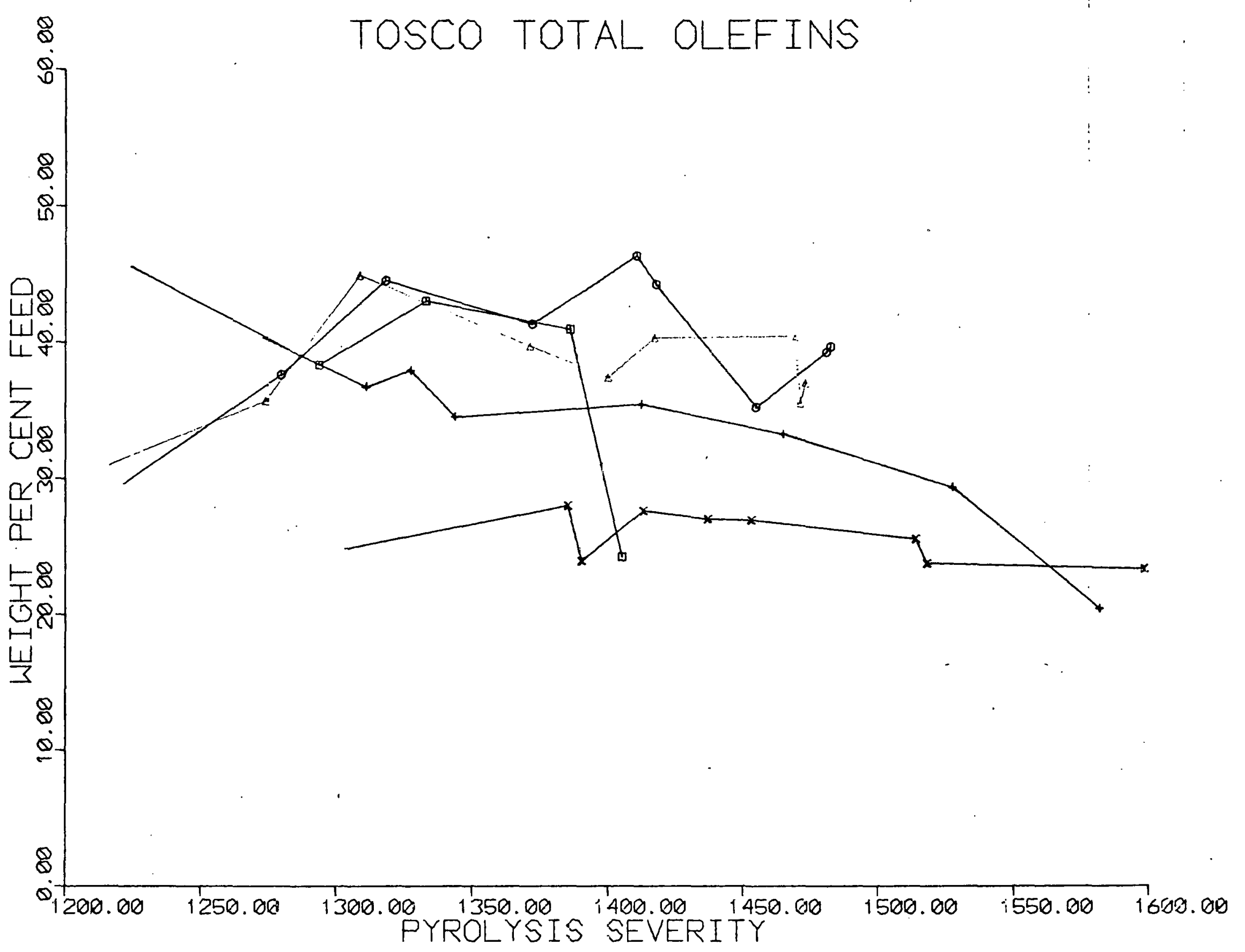




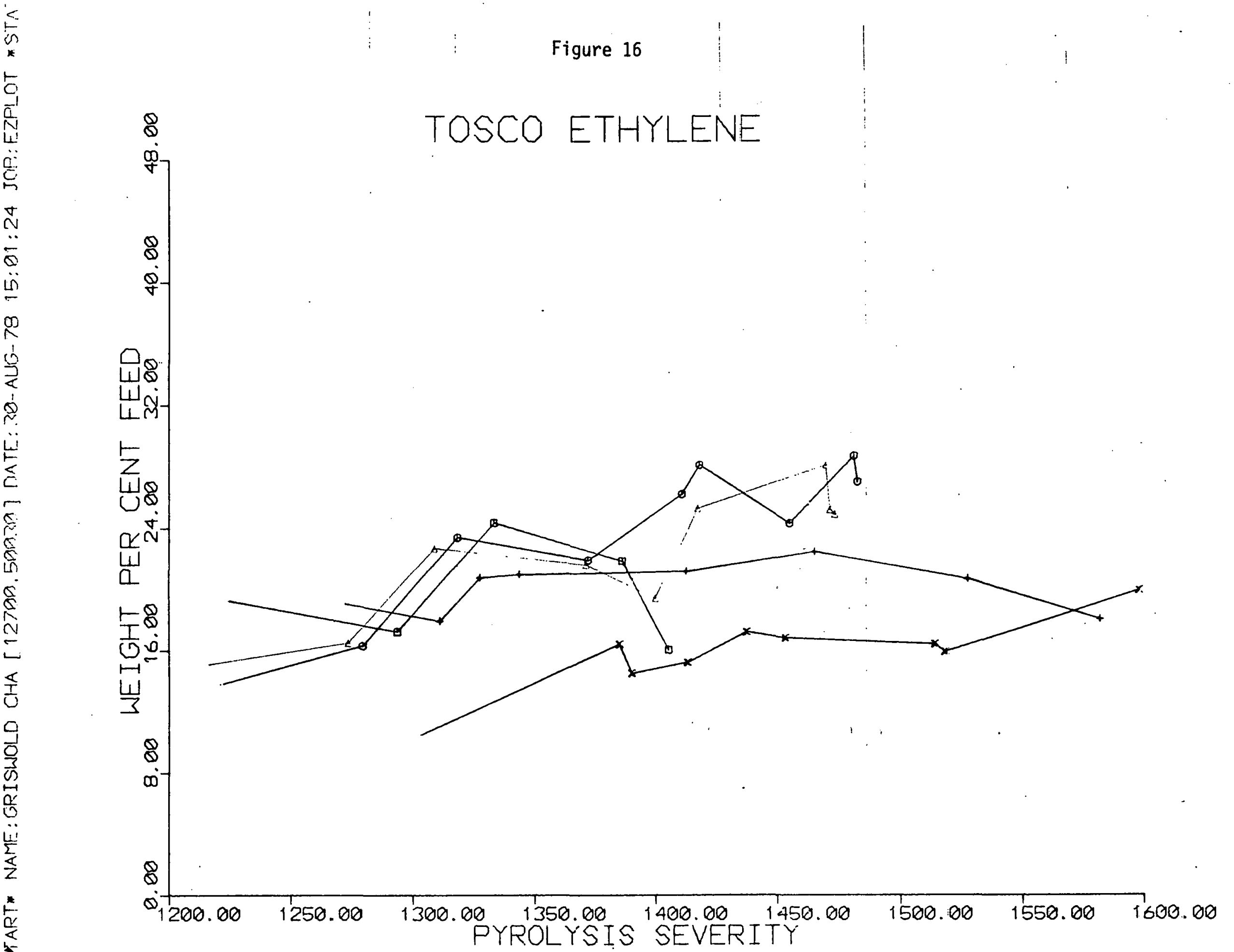


Figure 17

TOSCO PROPYLENE

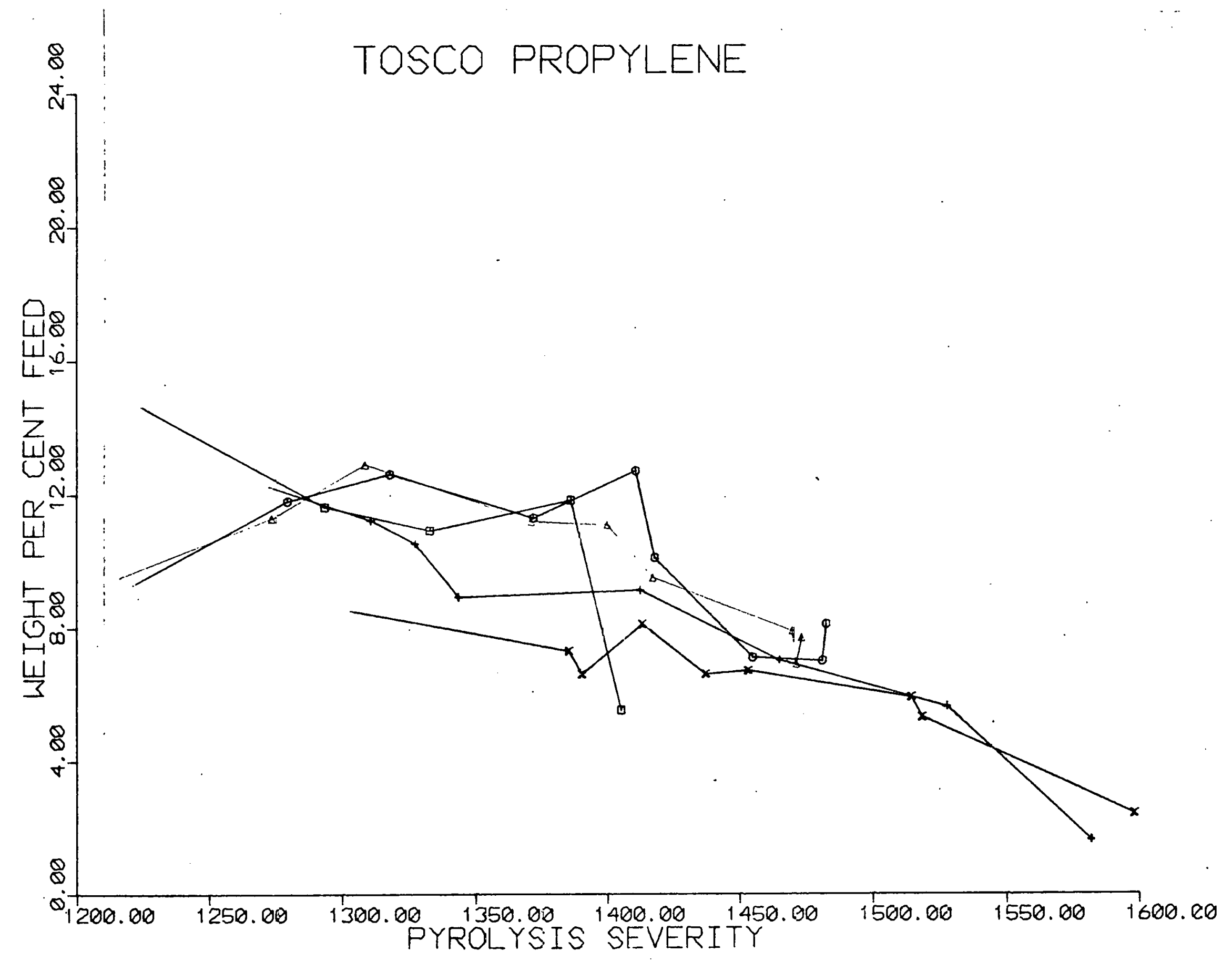




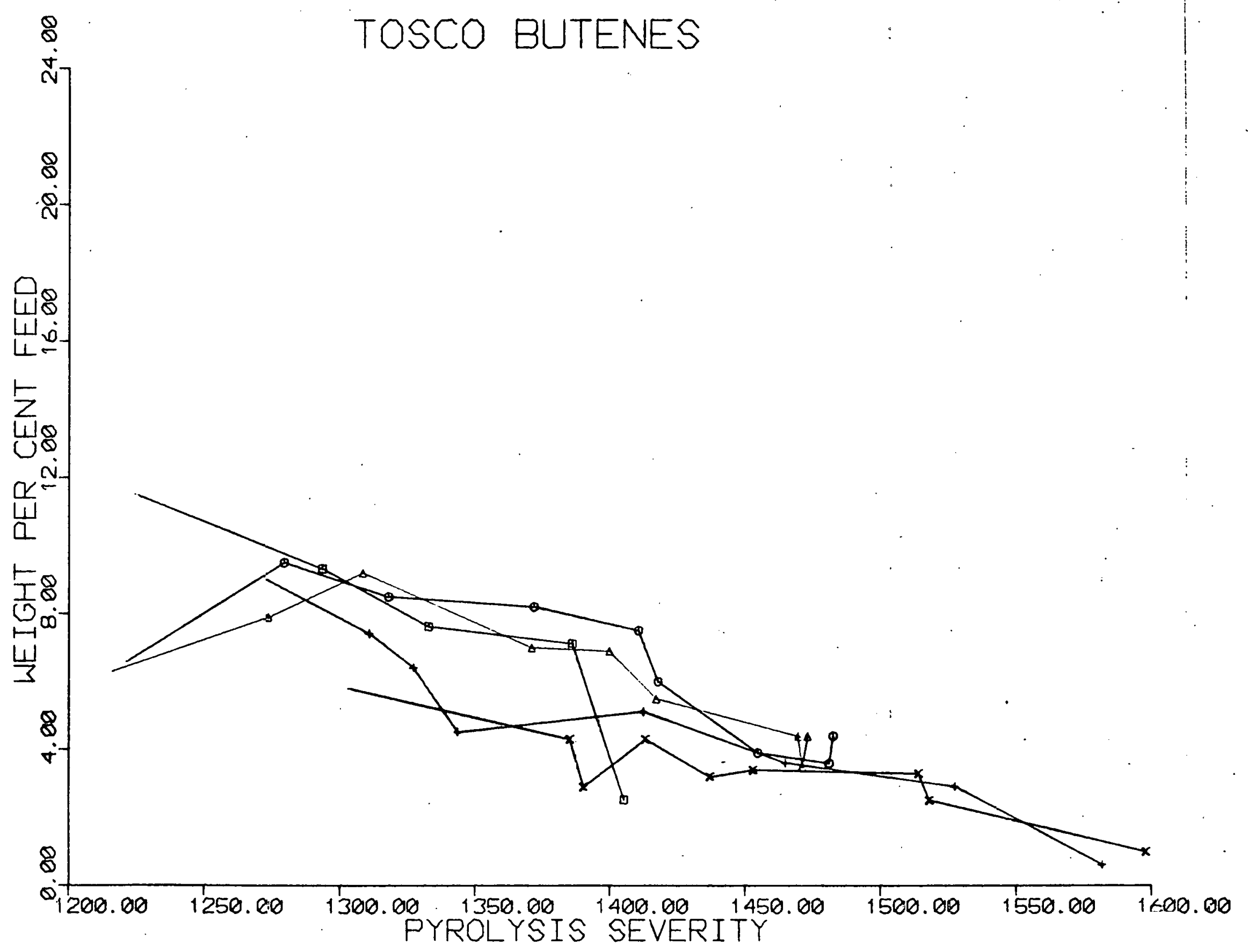


Task 4: Analysis and Measurements on Feedstocks and Products

Analyses of liquid products from the non-hydrogenated whole oils and $\therefore$ vacuum distillates were completed during the previous quarter and reported in the last quarterly progress report.

\section{Task 5: Data Correlation}

During this quarter, the correlation effort was extended to encompass the hydrogenated samples of the vacuum distillates of both the Tosco II and simulated in-situ shale oils in a fashion similar to that presented in the last quarterly report. (June 5, 1978). The effort was concentrated on finding the best exponent $\alpha$ in the equation:

$$
s=T \theta^{\alpha}
$$

where

$$
\begin{aligned}
& S \quad \text { is Severity factor } \\
& T \quad \text { is Tempature, }{ }^{{ }^{O}} \mathrm{~F} \\
& \theta \quad \text { is residence time, sec. }
\end{aligned}
$$

Also, the use of internal measures of severity (Propylene/ethylene ratio) was investigated. Table 5 gives the results for the best individual and overall exponent $\alpha$ for the major components and samples. The best overall exponents for the hydrogenated feedstocks varied from $.03-.04$. Due to sample gasification, the severely hydrogenated Tosco II oil pyrolysis results were not correlated. Considerable variation can be seen for individual components. The yield of propylene was correlated with an exponent of 0.06 and the results can be found in figures 19 to 23 and Table 6 .

The yield data were plotted against the internal severity measure Propylene to ethylene ratio - and found to correlate rather well as can be 
seen from figures 24 to 28 .

As was stated in the last quarterly report, the external severity function, $S$, can easily be related to the internal severity (propylene/ ethylene ratio) by the combined use of figures 24 to 28 and figures 19 to 23 or Table 6 . 
TABLE 5

Summary of Results for Exponent $\alpha$ for Hydrogenated Samples

\begin{tabular}{|l|l|l|l|l|r|}
\hline \multirow{2}{*}{ Component } & \multicolumn{3}{|c|}{ Laramie } & \multicolumn{2}{c|}{ Tosco II } \\
\cline { 2 - 6 } & 6201 & 6204 & 6202 & 6205 & 6206 \\
\hline $\mathrm{C}_{2} \mathrm{H}_{4}$ & 0.01 & 0.03 & 0.0 & 0.0 & 0.01 \\
$\mathrm{C}_{3} \mathrm{H}_{6}$ & 0.07 & 0.01 & 0.06 & 0.04 & 0.07 \\
$\mathrm{C}_{4} \mathrm{H}_{6}$ & 0.06 & 0.04 & 0.03 & 0.03 & 0.06 \\
$\mathrm{C}_{4} \mathrm{H}_{8}{ }^{\mathrm{S} S}$ & 0.07 & 0.02 & 0.04 & 0.05 & 0.07 \\
$\mathrm{CH}_{4}$ & 0.02 & 0.06 & 0.02 & 0.03 & 0.02 \\
\hline Overal1 & 0.04 & 0.03 & 0.04 & 0.03 & 0.04 \\
\hline
\end{tabular}




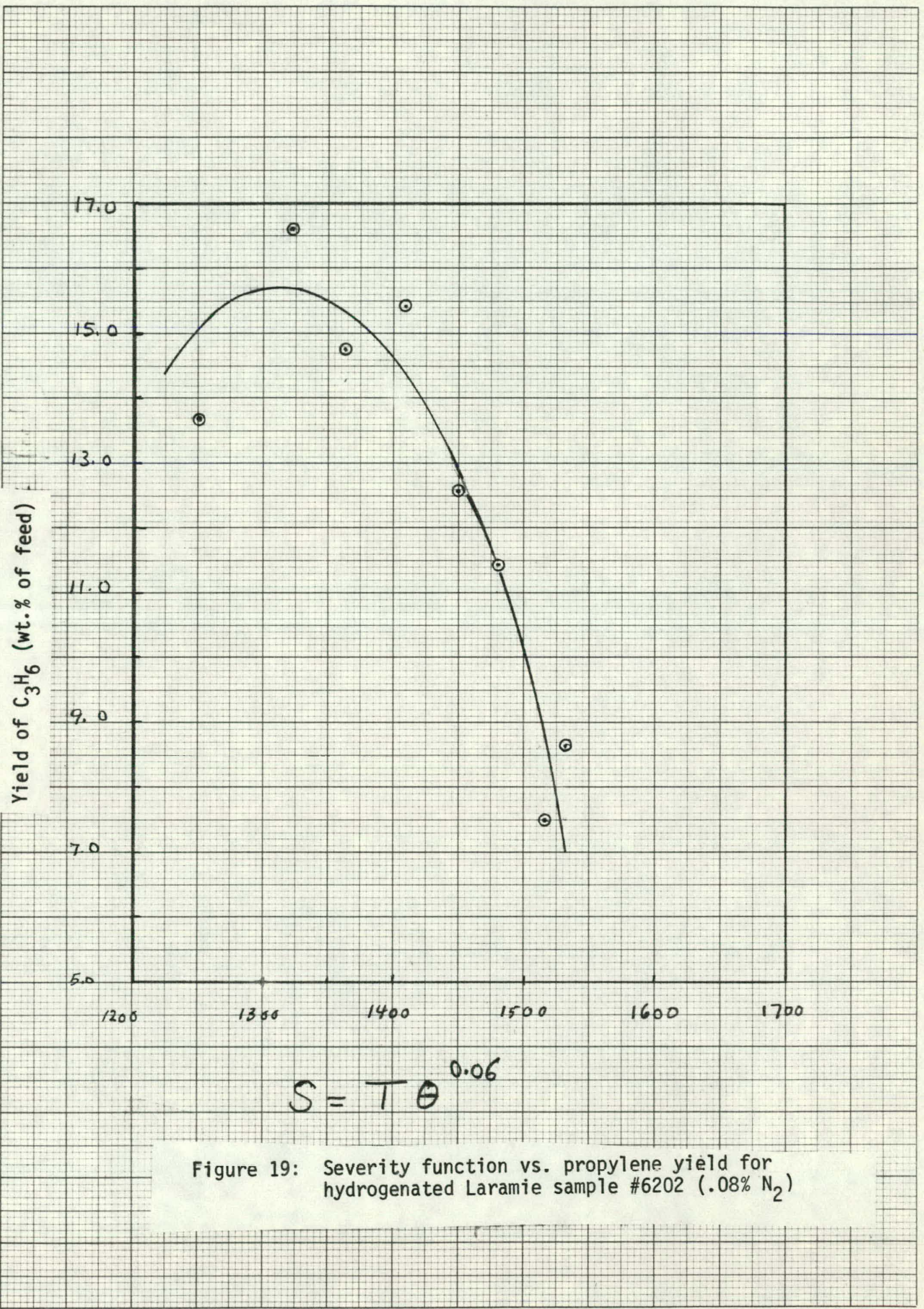




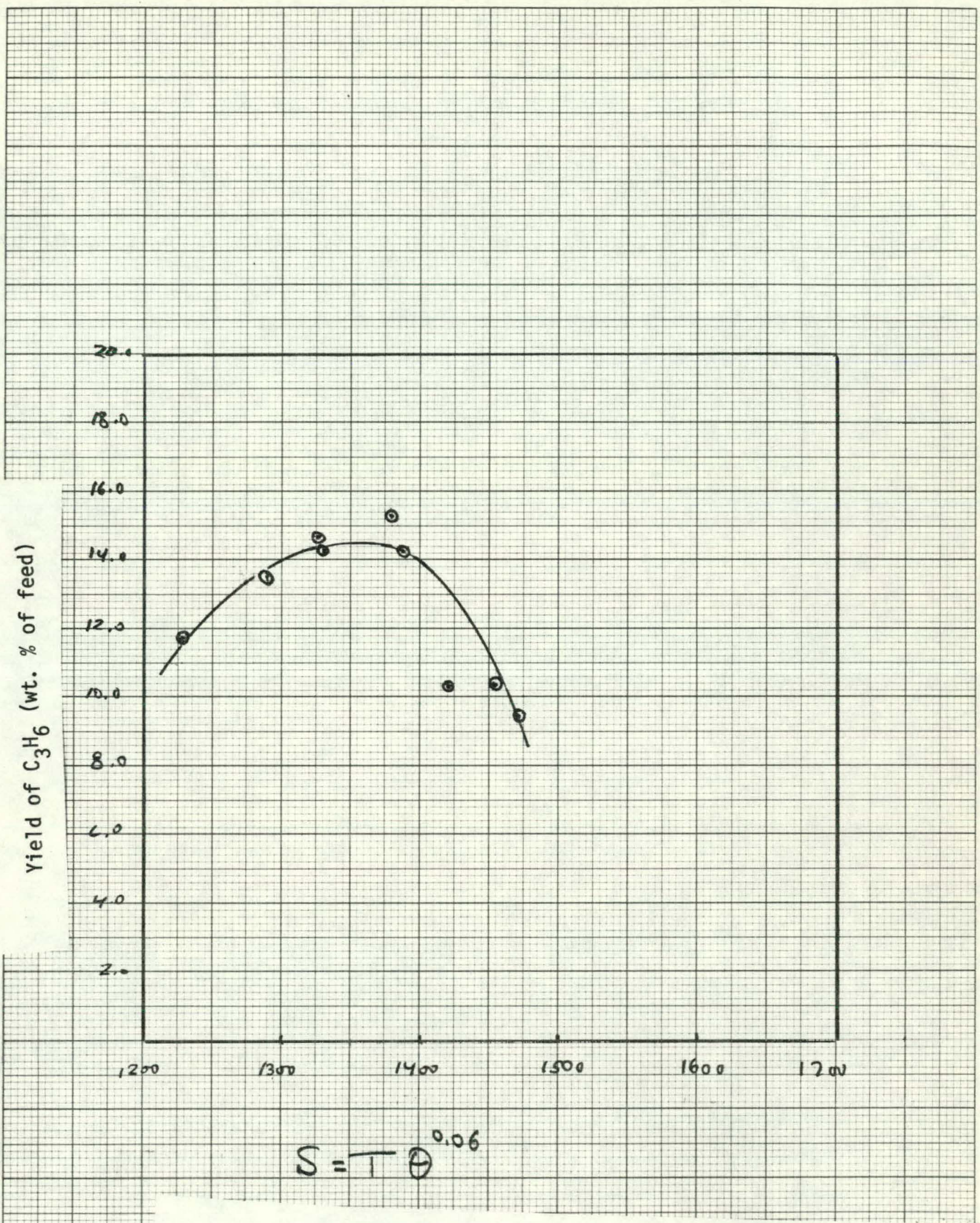

Figure 20: Severity function vs. propylene yield for hydrogenated Laramie Sample \#6204 $\left(0.73 \% \mathrm{~N}_{2}\right)$

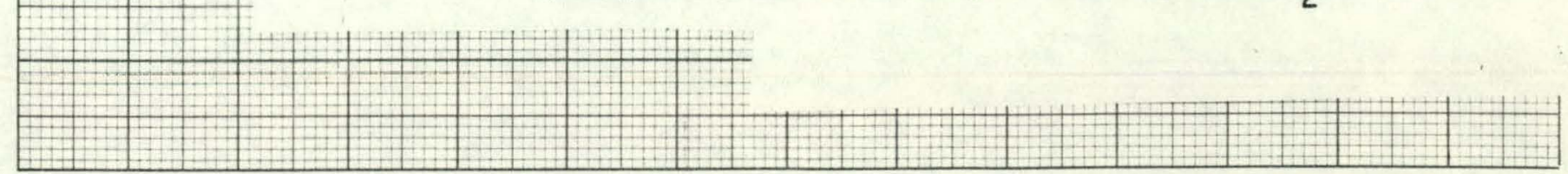




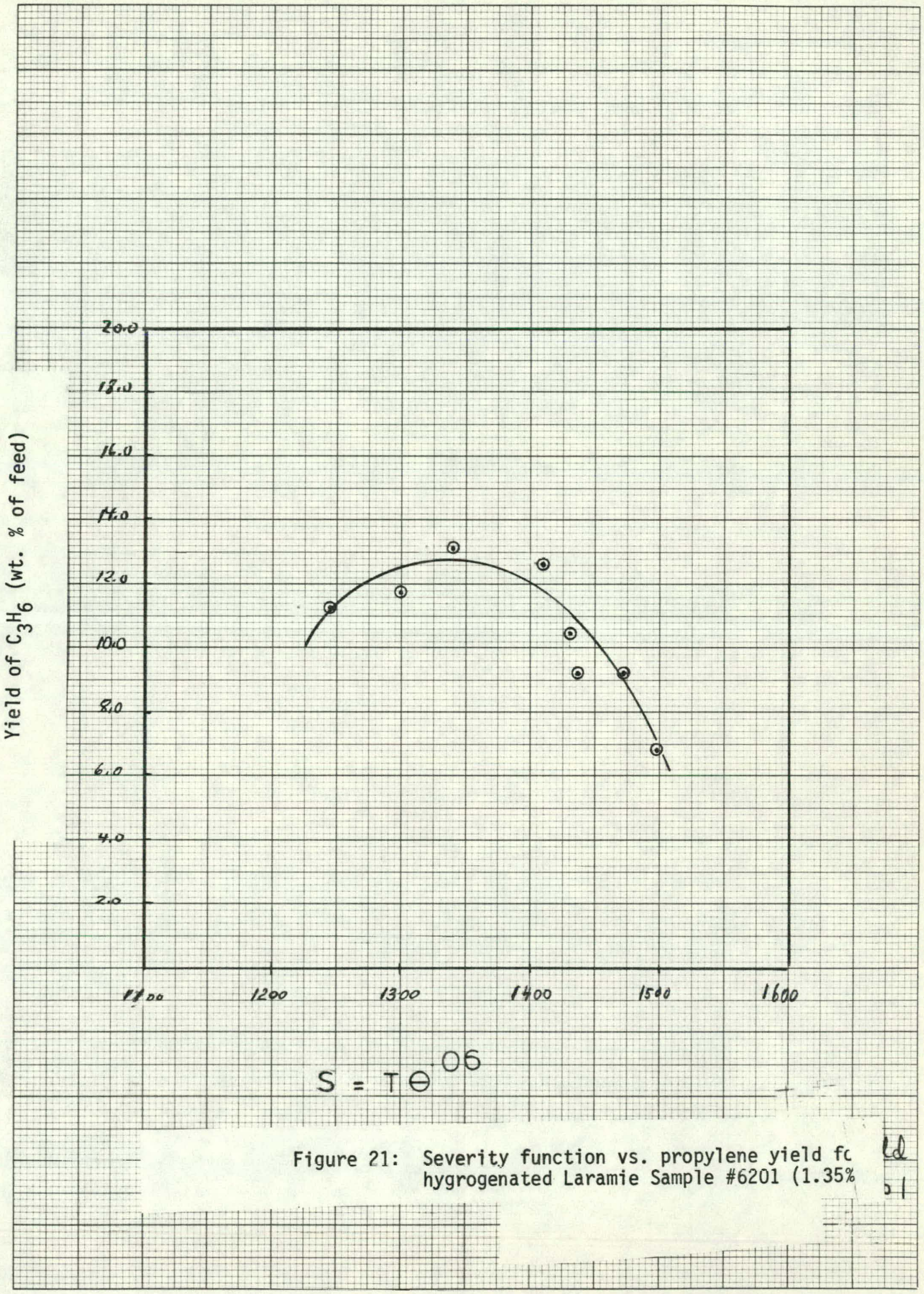




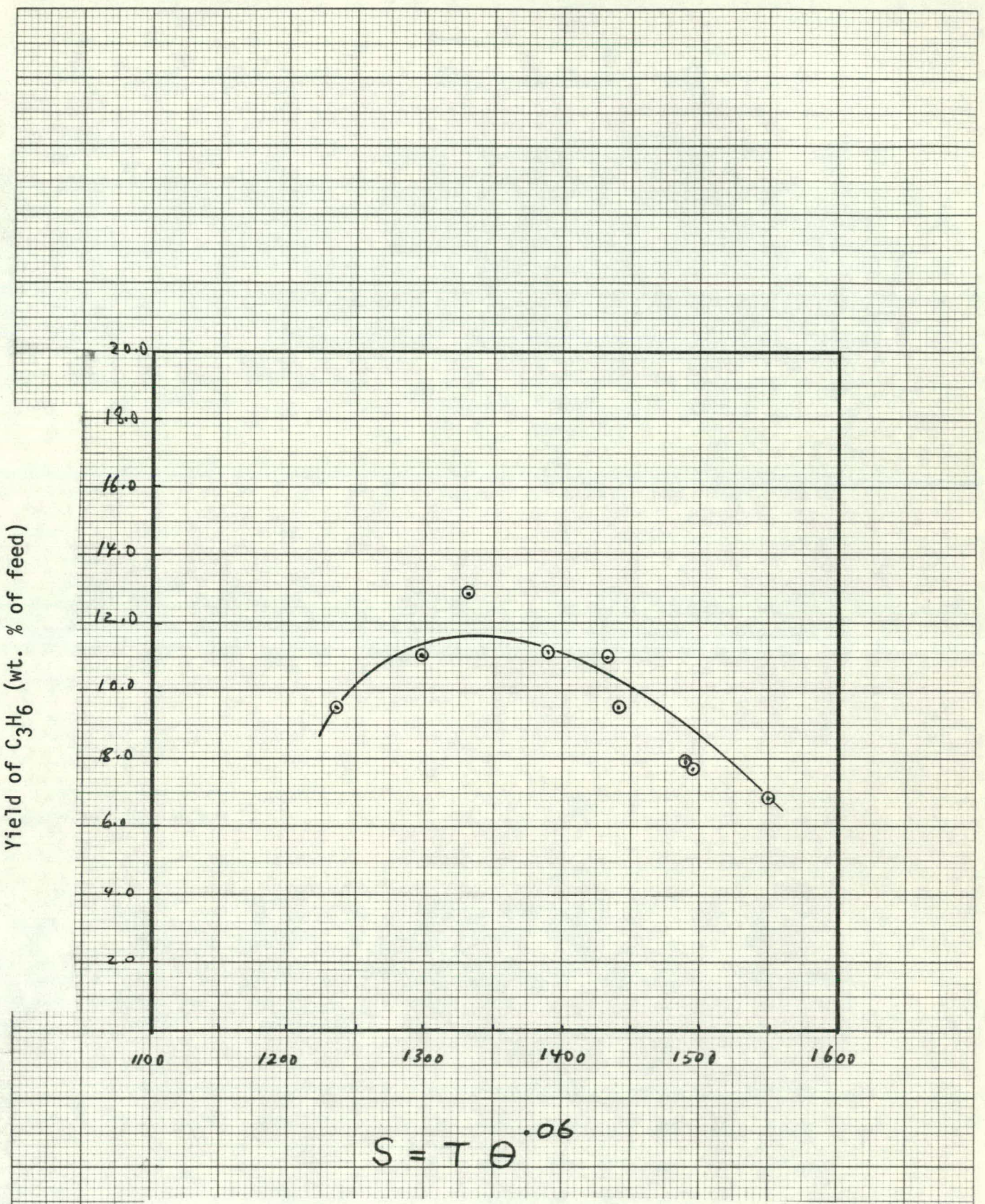

Figure 22: Severity function vs. propylene yield for hydrogenated Tosco II Sample \# $6025\left(1.55 \% \mathrm{~N}_{2}\right)$ 
TABLE 6

Values of the Regression Coefficient for Propylene $\left(S=T \theta^{006}\right)$

$$
Y=A_{0}+A_{1} S+A_{2} S^{2}+A_{3} S^{3}
$$

\begin{tabular}{|c|c|l|l|l|l|}
\hline $\begin{array}{c}\text { Sample } \\
\text { Feed }\end{array}$ & \multicolumn{1}{|c|}{ Ao } & \multicolumn{1}{|c|}{$\mathrm{A}_{1}$} & \multicolumn{1}{c|}{$\mathrm{A}_{2}$} & \multicolumn{1}{c|}{$\mathrm{A}_{3}$} & $\star \mathrm{R}^{2}$ \\
\hline 6201 (NTU) & $-2.106 \times 10^{2}$ & $2.387 \times 10^{-1}$ & $1.887 \times 10^{-5}$ & $-5.425 \times 10^{-8}$ & 0.84 \\
6204 (NTU) & $-2.001 \times 10^{3}$ & 4.044 & $-2.670 \times 10^{-3}$ & $5.781 \times 10^{-7}$ & 0.83 \\
6202 (NTU) & $-1.848 \times 10^{3}$ & 3.767 & $-2.505 \times 10^{-3}$ & $5.459 \times 10^{-7}$ & 0.93 \\
6205 (Tosco) & $-1.937 \times 10^{3}$ & 4.062 & $-2.802 \times 10^{-3}$ & $6.383 \times 10^{-7}$ & 0.91 \\
6206 (Tosco) & $-1.934 \times 10^{3}$ & 4.004 & $-2.723 \times 10^{-3}$ & $6.111 \times 10^{-7}$ & \\
& & & & & \\
\hline
\end{tabular}

$* R^{2}=$ Coefficient of regression 


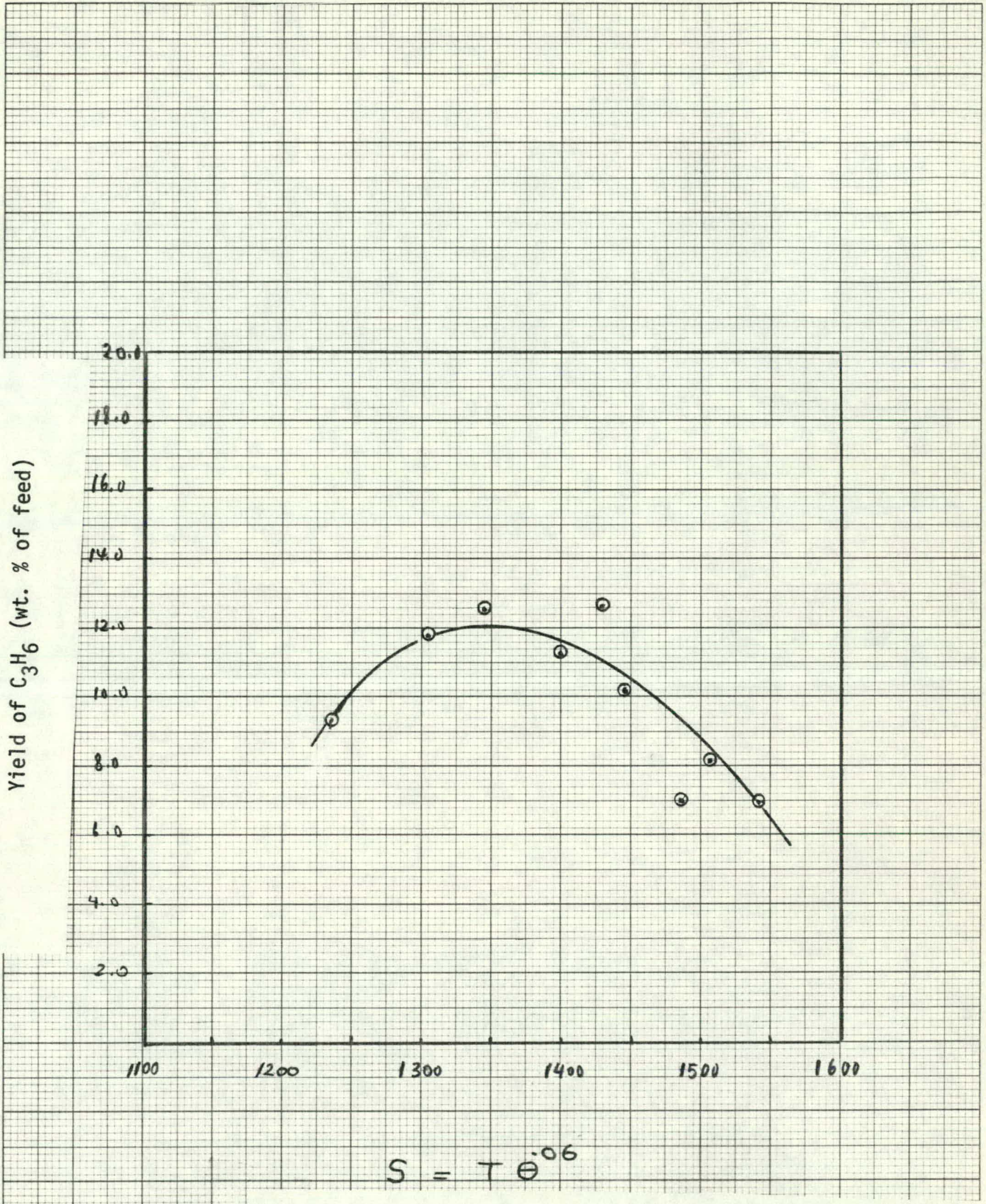

Figure 23: Severity function vs. Propylene Ethylene Ratio for hydrogenated Tosco II Sample \#6206 $\left(0.82 \% \mathrm{~N}_{2}\right)$ 


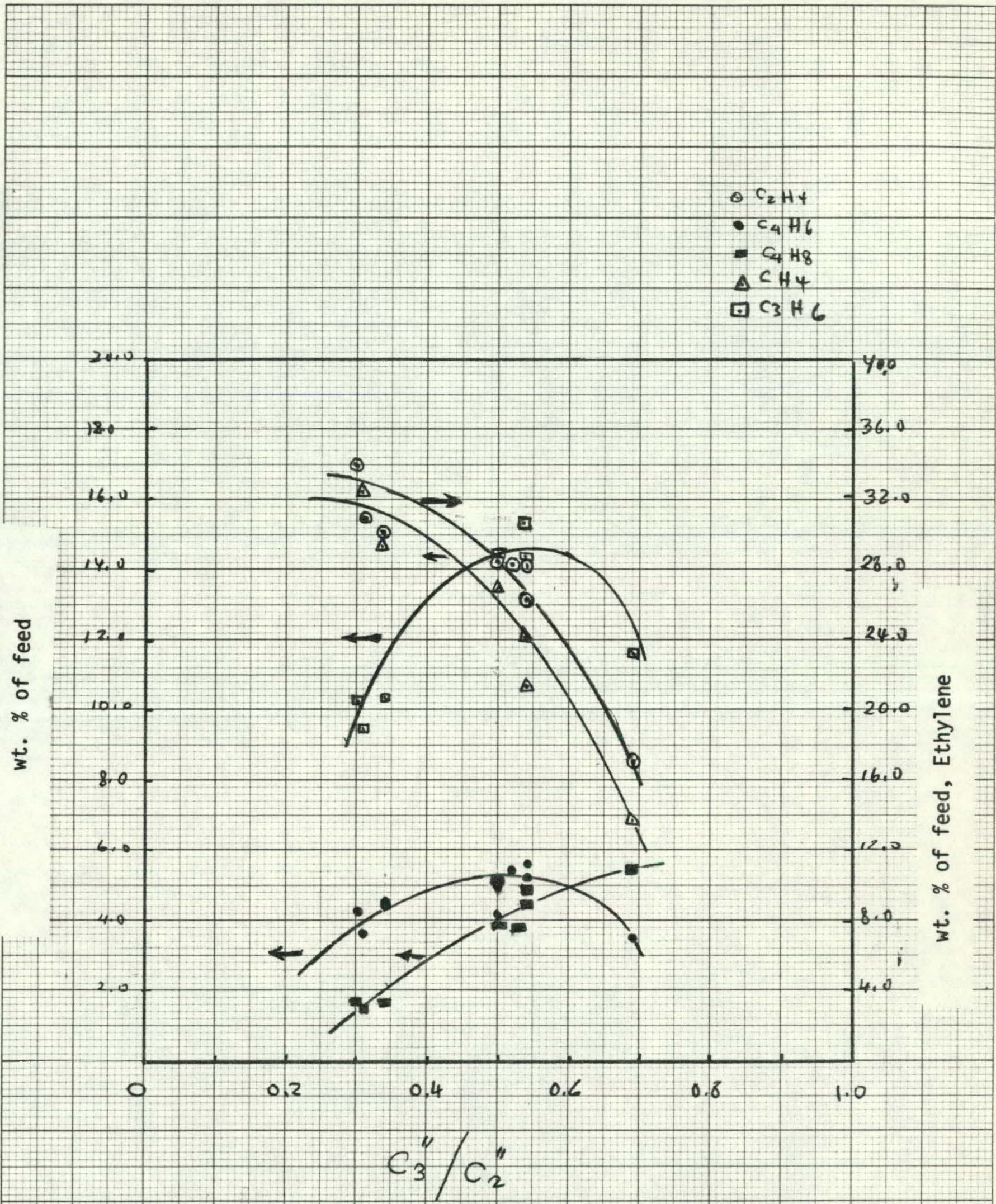

Figure 25: Yield vs. Propylene/Ethylene ratio for hydrogenated Laramie Sample \#6204 $\left(0.73 \% \mathrm{~N}_{2}\right)$ 


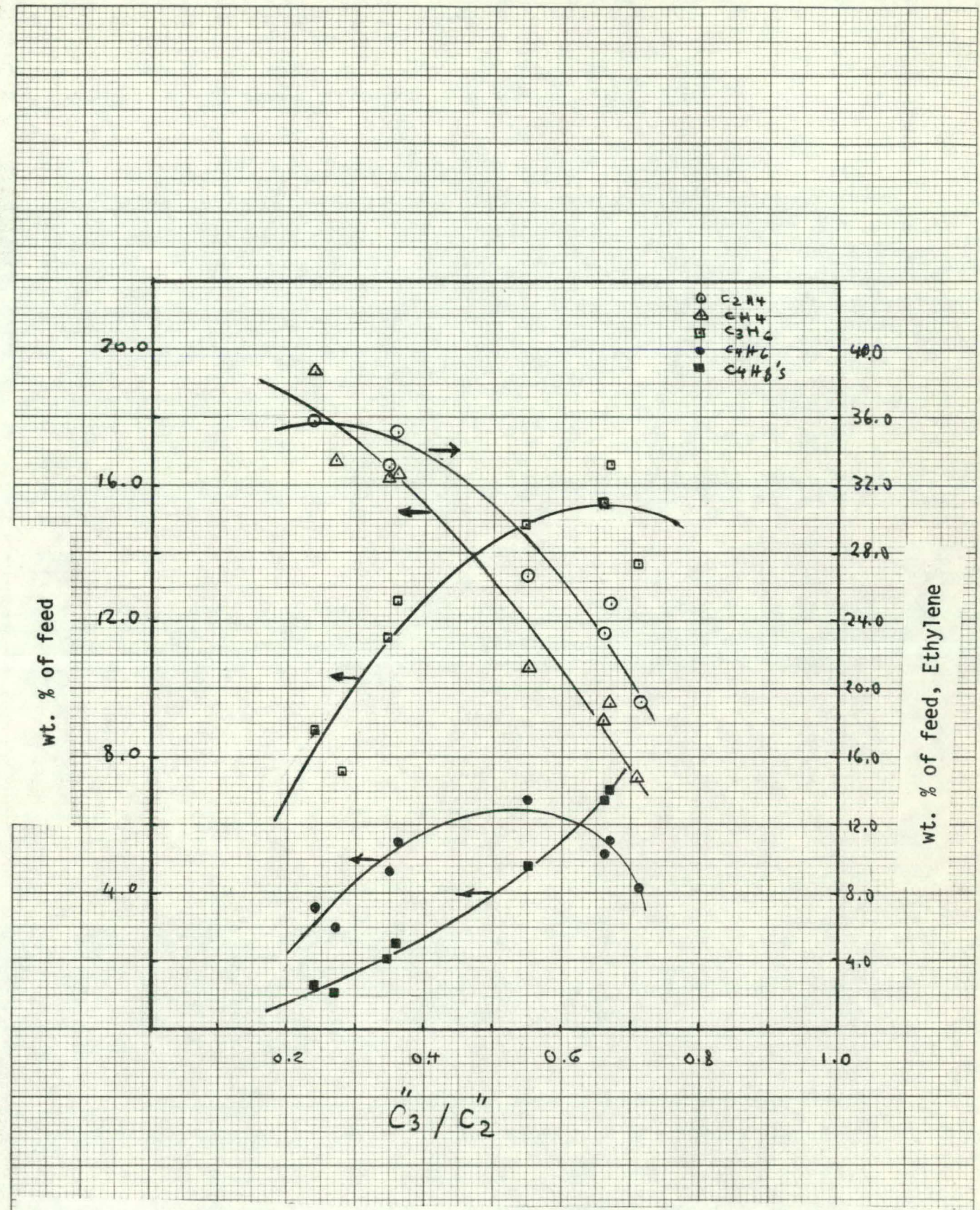

Figure 24: Yield vs. Propylene/Ethylene ratio for hydrogenated Laramie Sample \#6202 (.08\% $\left.\mathrm{N}_{2}\right)$ 


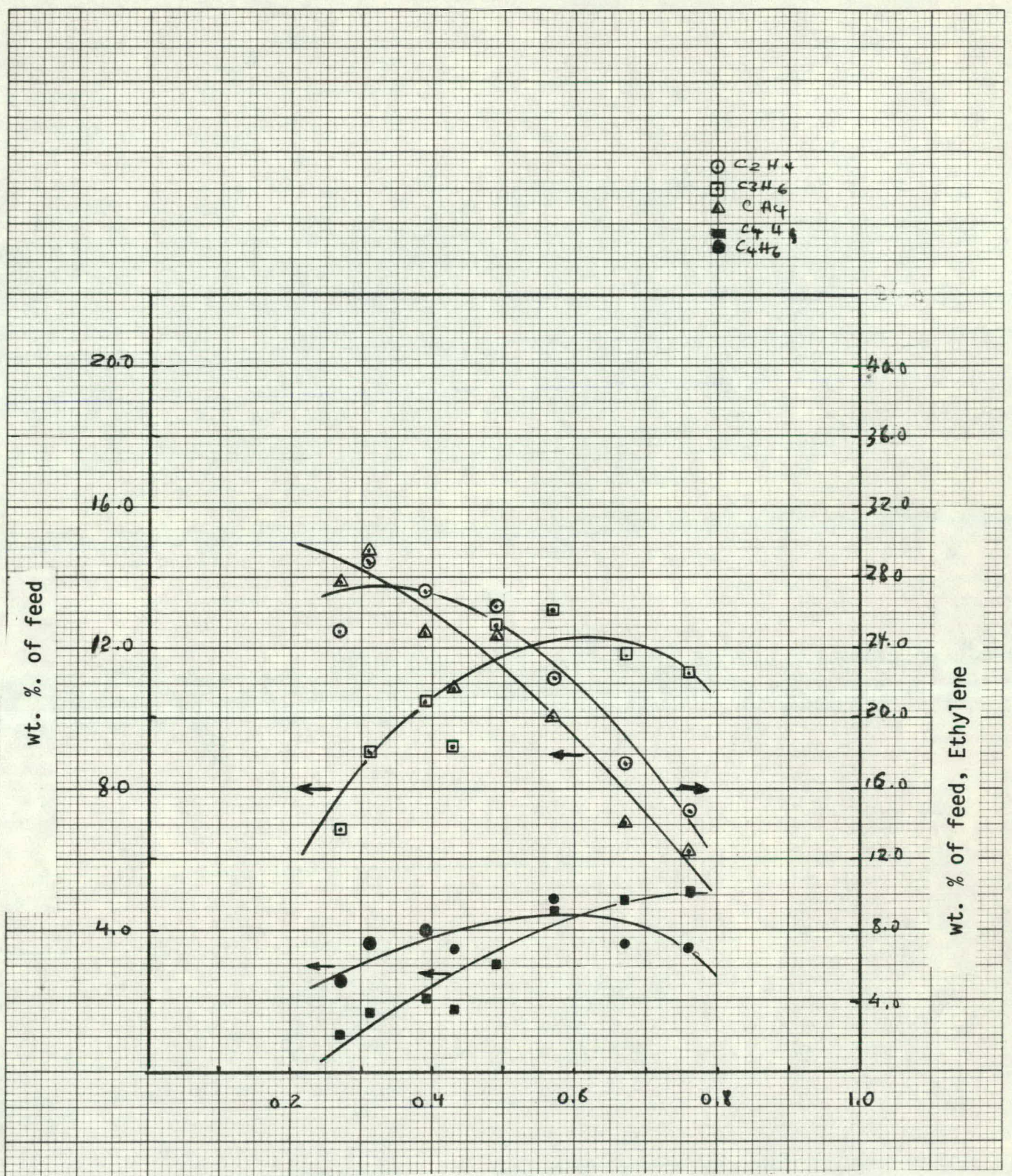

Figure 26: Yield vs. Propylene/Ethylene ratio for hydrogenated Laramie Sample \#6201 $\left(1.35 \% \mathrm{~N}_{2}\right)$ 


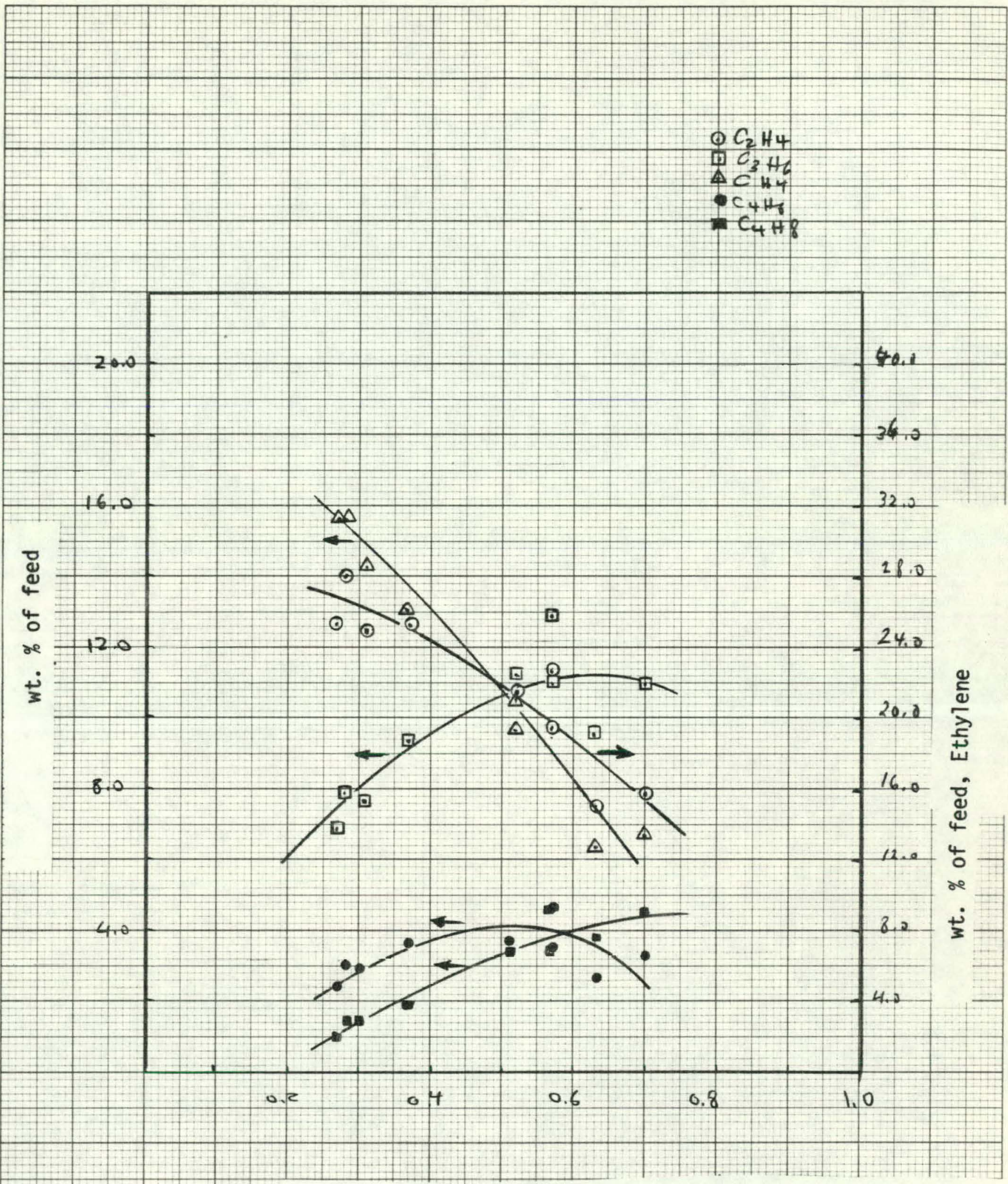

Figure 27: Yield vs. Propylene/Ethylene ratio for hydrogenated Tosco II Sample \#6205 $\left(1.55 \% \mathrm{~N}_{2}\right)$ 


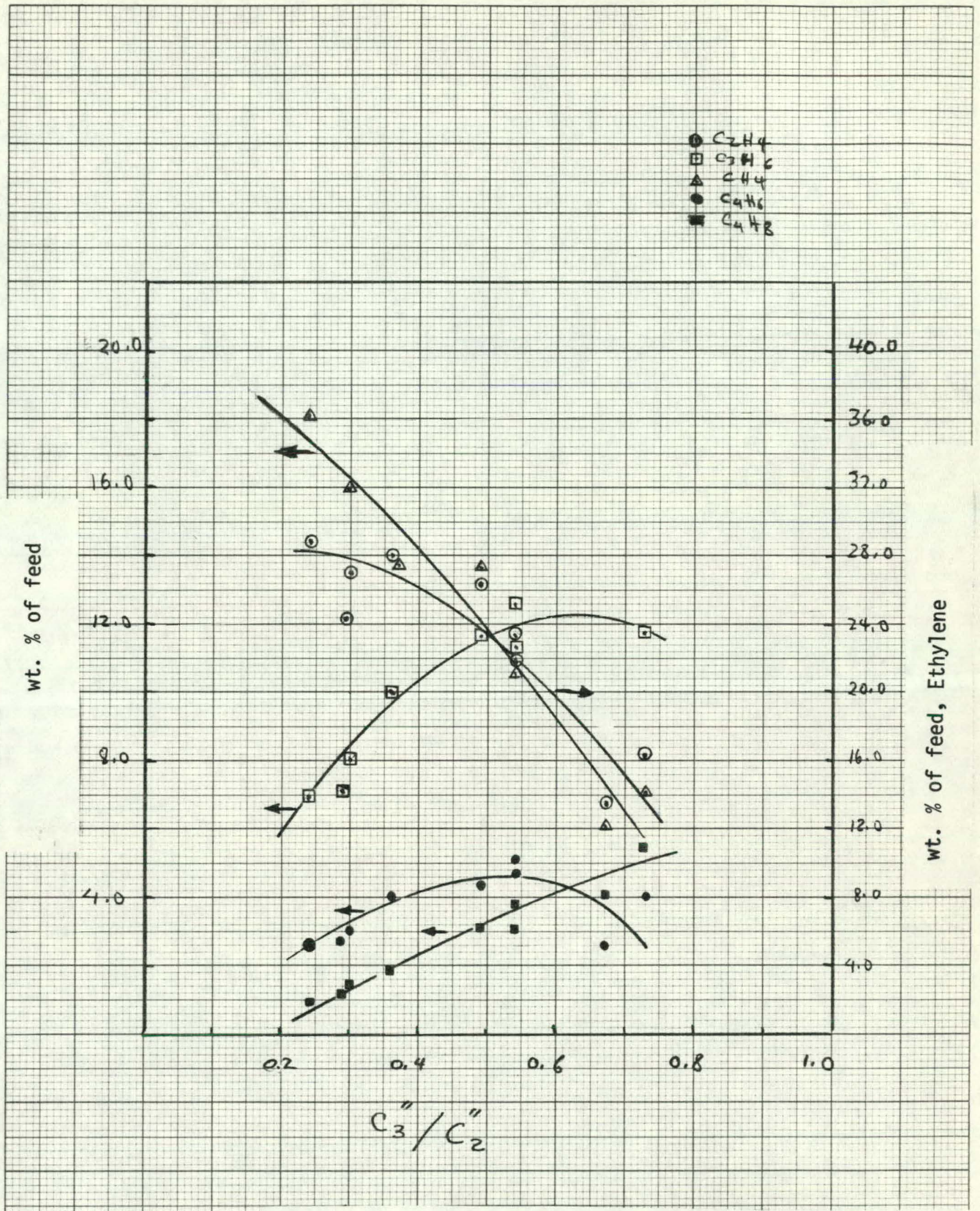

Figure 28: Yield vs. Propylene/Ethylene ratio for hydrogenated Tosco II Sample \# $6206\left(0.82 \% \mathrm{~N}_{2}\right)$ 


\section{Task 7:}

Feedstocks, liquid products, and water samples have been retained for each of the experimental runs. Samples of each of the feed samples have been shipped to the Laramie Energy Research Center.

\section{Projections for Next Quarter, September 1978 - November 1978}

All experimental runs originally outlined as a part of the contract have been completed. During the next, quarter, additional experimental runs will be obtained with the Tosco II and simulated in-situ whole oil at short residence times in order to determine kinetic parameters for our required correlation effort. Further, experimental runs will be obtained with a Paraho severly hydrogenated oil in order to better understand the undesirable gasification reactions. Work will continue on our correlation efforts.

\section{Conclusions}

The experimental program originally outlined as a part of the contract has been completed. Additional experimental runs are being performed in order to define kinetic model parameters required for our correlation work and to investigate the unexpected gasification reactions which occur at high severity for low nitrogen oil samples. 


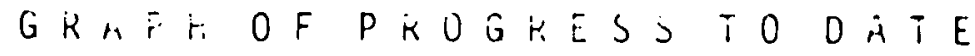

YEAR 1

June Sept. Dec. Mar. June

TASK 1

Equipment Design

and Construction

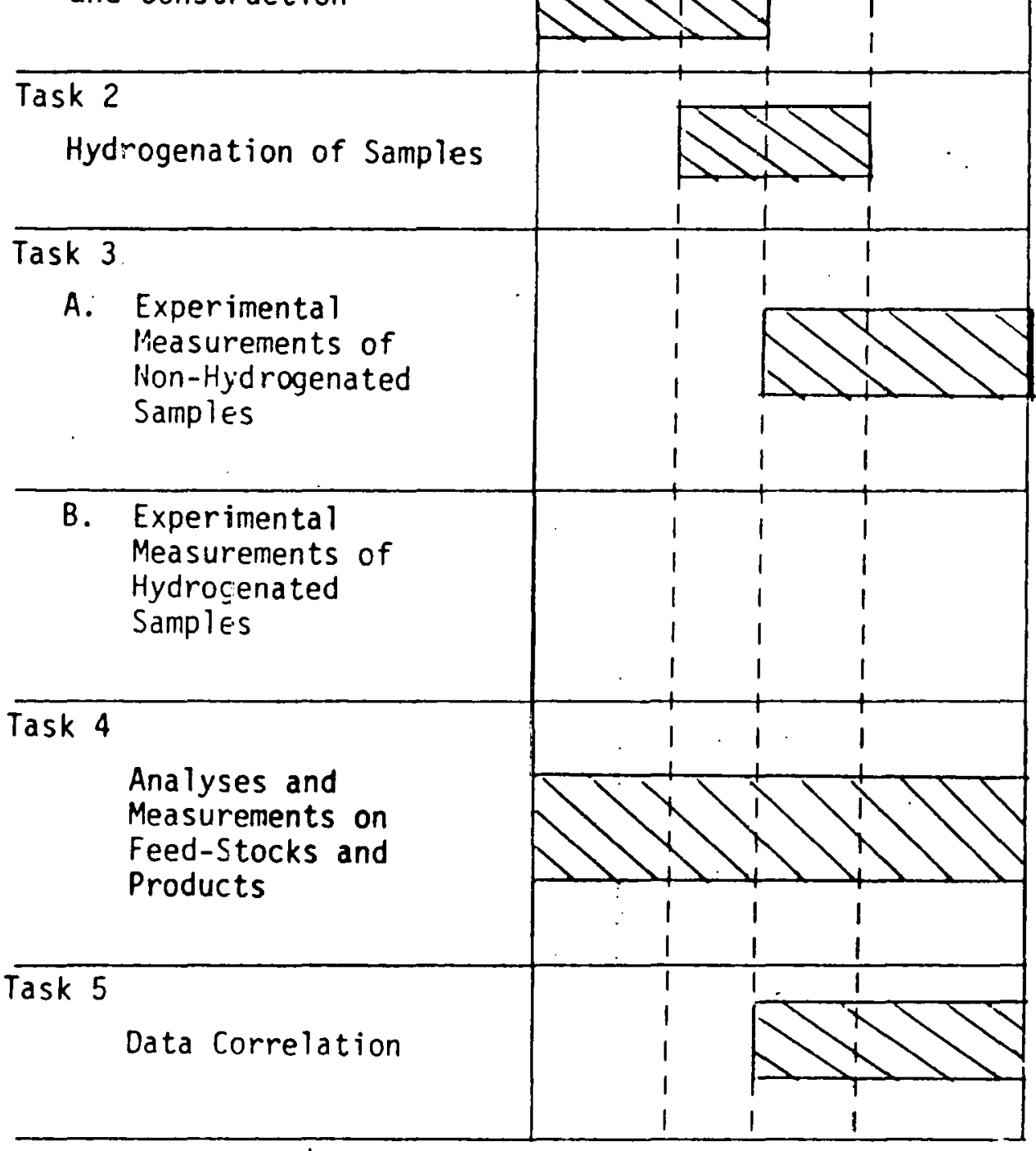

Schedule of Work $\begin{array}{ccccc}1 & 1 & 1 & 1 & 1 \\ 1976 & 1976 & 1976 & 1977 & 1977\end{array}$

mis i

인
을
운

Progress to Date
YEAR 2

Sept. Dec. Mar June Sept. Dec.

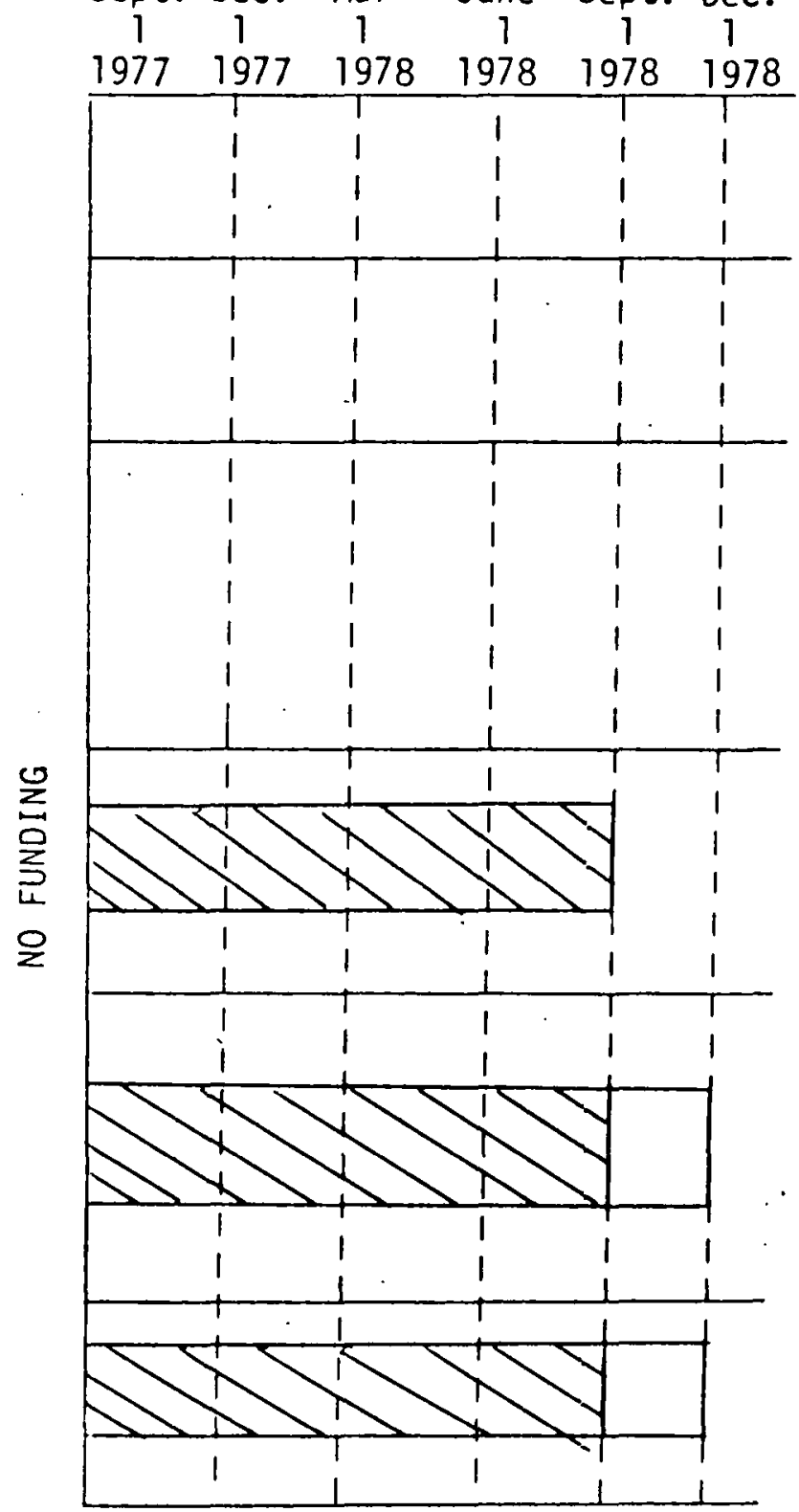


APPENDIX

DETAILED RESULTS 
$0:$

RUM NUABER $=$ HO51878027

0

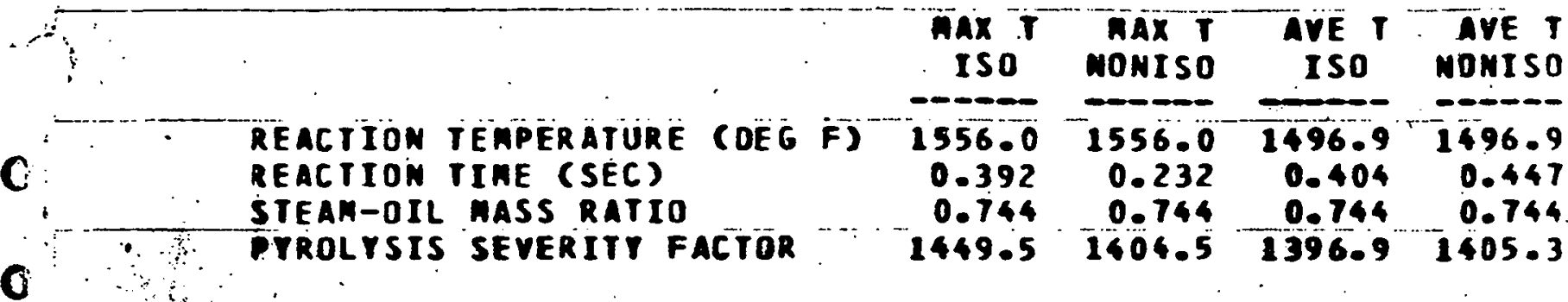

CASEOUS PRODUCTS

C

IT OF FEED 62.14

C SCFILB OF FEED 9.94

$\mathrm{C}^{\circ}$

COMPONENT

HYOROGEM

CARBON MONOXIDE

METHANE

PROPANE

PROPYLENE

M-BUTANE

HYDROGEN SULFIDE

1-BUTENE

ISOBUT TLENE

TRANS-2-BUTENE

CIS-2-BUTENE

1-3 BUTADIENE

CARBON DIOXIDE

ETHYLENE

ETHANE

ISOBUTANE

MOL \&6AS WT \& GAS UT \&FEED SCFIE FEED

\begin{tabular}{cccc} 
& & & \\
\hline 12.64 & 1.07 & 0.67 & 1.26 \\
2.71 & 3.19 & 1.98 & 0.27 \\
30.62 & 20.69 & 12.86 & 3.04 \\
0.25 & 0.46 & 0.29 & 0.02 \\
9.49 & 16.83 & 10.46 & 0.94 \\
0.21 & 0.53 & 0.33 & 0.02 \\
0.00 & 0.00 & 0.00 & 0.00 \\
0.86 & 1.99 & 1.24 & 0.08 \\
0.00 & 0.00 & 0.00 & 0.00 \\
0.48 & 1.15 & 0.71 & 0.05 \\
0.06 & 0.15 & 0.09 & 0.01 \\
2.89 & 6.59 & 4.09 & 0.29 \\
0.11 & 0.21 & 0.13 & 0.01 \\
36.95 & 43.67 & 27.14 & 3.67 \\
2.76 & 3.47 & 2.16 & 0.27 \\
0.00 & 0.00 & 0.00 & 0.00 \\
\hline & & &
\end{tabular}

C

LIQUID PRODUCTS

UT \& DF FEED 37.86

SOLID PRODUCTS

UTR OF FEED 0.00

C

C

c

C

(1) 


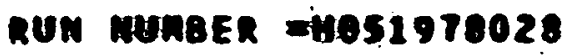

Q

C
$C$
$C$
$C$
$C$

$C:$ REACTION TEMPERATURE (DEG F)

\begin{tabular}{|c|c|c|c|}
\hline ISo & $\begin{array}{l}\operatorname{nax} T \\
\text { HonIso }\end{array}$ & 150 & $\begin{array}{r}\text { AVE } \\
\text { MOAISO }\end{array}$ \\
\hline 8 & $\begin{array}{r}1447 \\
0.7 \\
0.7 \\
1313\end{array}$ & $\begin{array}{r}1400 \\
0.4 \\
1310\end{array}$ & $\begin{array}{r}140 \\
0 \\
0 \\
131\end{array}$ \\
\hline
\end{tabular}

REACTION TIME (SEC)

STEAN-OIL MASS RATIO

$\because$ PYROLYSIS SEVERITY. FACTOR

$1346.0 \quad 1313.0$

1310.1

1314.8

GASEOUS PRODOUCTS

UT 8 OF FEED 60.32

SCF ILB OF FEED 8.59

COMPONENT

MYOROGEN

CARBON MONOXIDE

METHANE

PROPANE

PROPTLENE

N-BUTANE

HYOROGEN SULFIDE

1-BUTENE

ISOBUTYLENE

TRANS-2-BUTENE

CIS-2-BUTENE

1-3 BUTADIENE

CARBON DIOXIDE

ETHYLENE

ETHANE

ISOBUTANE

\begin{tabular}{cccc} 
HOL $36 A S$ & UT 7 GAS & WT 8 FEED & SCF/ FEED \\
\hline 8.34 & 0.63 & 0.38 & 0.72 \\
2.45 & 2.57 & 1.55 & 0.21 \\
27.62 & 16.61 & 10.02 & 2.37 \\
\hline 0.52 & 0.85 & 0.52 & 0.04 \\
13.76 & 21.70 & 13.09 & 1.18 \\
0.16 & 0.36 & 0.21 & 0.01 \\
\hline 0.00 & 0.00 & 0.00 & 0.00 \\
2.88 & 6.05 & 3.65 & 0.25 \\
0.00 & 0.00 & 0.00 & 0.00 \\
0.50 & 1.06 & 0.64 & 0.04 \\
0.20 & 0.42 & 0.25 & 0.02 \\
3.69 & 7.48 & 4.51 & 0.32 \\
\hline 0.10 & 0.17 & 0.10 & 0.01 \\
36.15 & 38.01 & 22.93 & 3.10 \\
3.64 & 4.10 & 2.47 & 0.31 \\
\hline 0.00 & 0.00 & 0.00 & 0.00
\end{tabular}

LIOUIO PRODUCTS

UT 8 OF FEED 39.68

SOLID PRODUCTS

UTI OF FEEO 0.00 


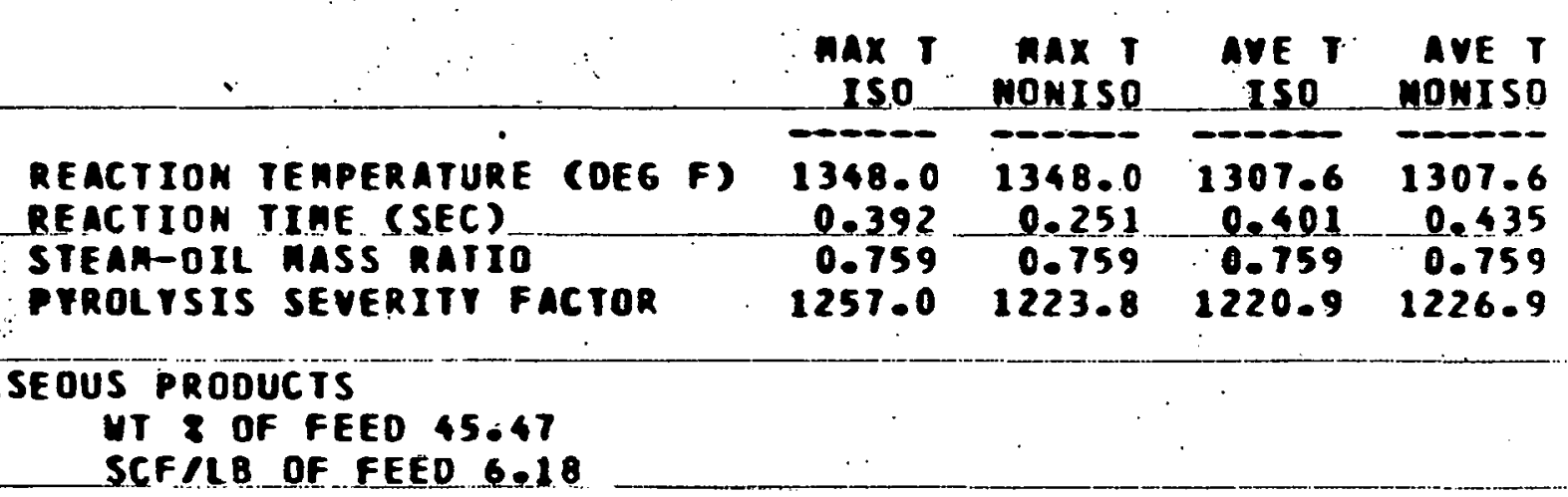

COMPONENT

$=---D$

MOL zGAS

HYOROGEN

CARBON MONOXIDE

ME THANE

PROPANE

PRoptlene

N-BUTANE

HYOROGEN SULFIDE

1-BUTENE

ISOBUTYLENE

TRANS-2-BUTENE

CIS-2-BUTENE

1-3 BUTADIENE

CARBON OIOXIDE

ETHYLENE

ETHANE

ISOBUTANE

\section{$-\frac{2.01}{0.65}$}

2.51

26.36

0.64

16.48

0.16

0.00

4.68

0.00

0.57

0.34

3.89

0.07

32.57

4.71

0.00

\begin{tabular}{r}
01645 \\
\hline 0.65 \\
2.52 \\
13.99 \\
1.01 \\
24.84 \\
0.33 \\
0.00 \\
9.40 \\
0.00 \\
1.15 \\
0.69 \\
1.53 \\
0.12 \\
32.71 \\
5.07 \\
0.00
\end{tabular}

บT

$\frac{T \text { FEED }}{0.30}$

1. 15

6.36

0.46

11.29

0.15

0.00

4.27

0.00

0.52

0.31

3.43

0.05

14.87

2.31

0.00
SCF/A FEED

0.56

0.16

1.51

0.04

1.02

0.0 .1

0.00

0.29

0.00

0.04

.0 .02

0.24

0.00

2.01

0.29

0.00

LIOUIO PRODUCTS

WT 8 OF FEED 54.53

SOLID PRODUCIS

UTI OF FEED 0.00 


\section{RUN MUABER $=$ HOS2678030}

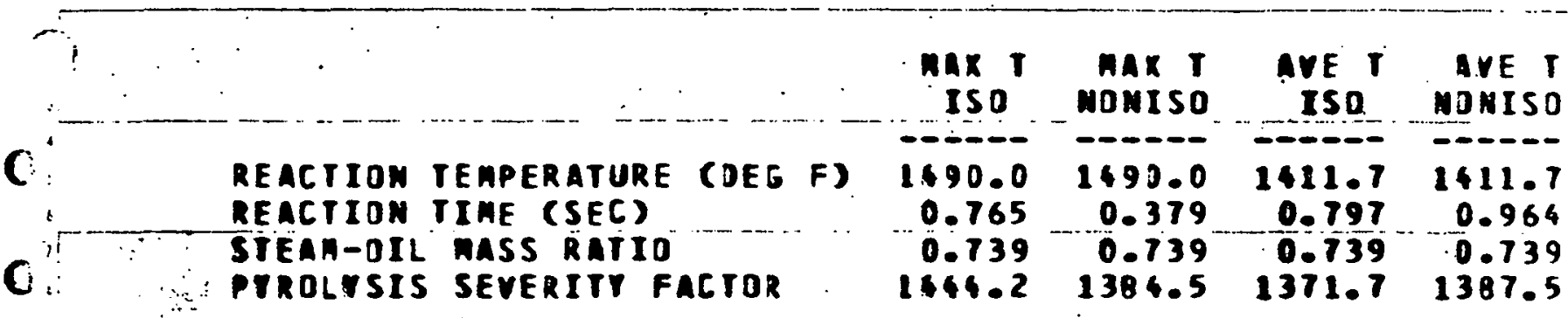

C

GASEOUS PRODUETS

YT 8 OF FEED 64.35

SCF/LB OF FEED 10.34

C.

COMPONENT

HTDROGEN

CARBON MONOXIDE

ME THANE

PROPANE

PROPYLENE

N-BUTANE

HTOROGEN SULFIDE

1-8UTENE

ISOBUTYLENE

TRANS-2-BUTENE

CIS-2-BUTENE

1-3 BUTAOIENE

CARBON DIOXIDE

ETHTLENE

ETHANE

ISOBUTANE

MOL $86 A S$ UT 2 GAS

WT 8 FEEO

SCF/ FEED.

$-$

14.10

1.20

0.77

4.23

28.88

5.01

3.26

0.32

19.60

12.61

0.59

0.38

11.07

19.71

0.17

0.42

0.03

1.48

0.04

3.50

0.00

0.00

0.40

0.94

0.11

0.26

1.56

3.57

0.25

0.33

12.68

0.27

0.03

2. 25

0.00

0.61

1.46

0.44

2.99

C.

34.22

40.62

3.20

4.07

0.00

0.00

0.17

0.03

1.14

0.02

0.00

0.15

0.00

0.04

2. 30

0.01

0.16

0.25

0.02

3.54

2.62

0.33

0.00

LIQUID PRODUCTS

UT OF FEED 35.65

SOLID PRODUCTS

UT OF FEEO 0.00

C 
?

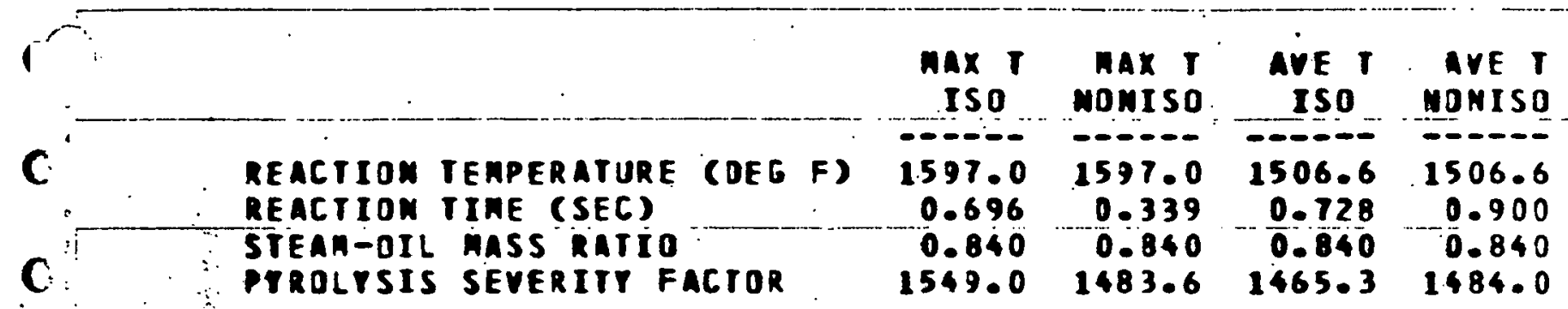

$C^{10}$ GASEOUS PRODUCTS

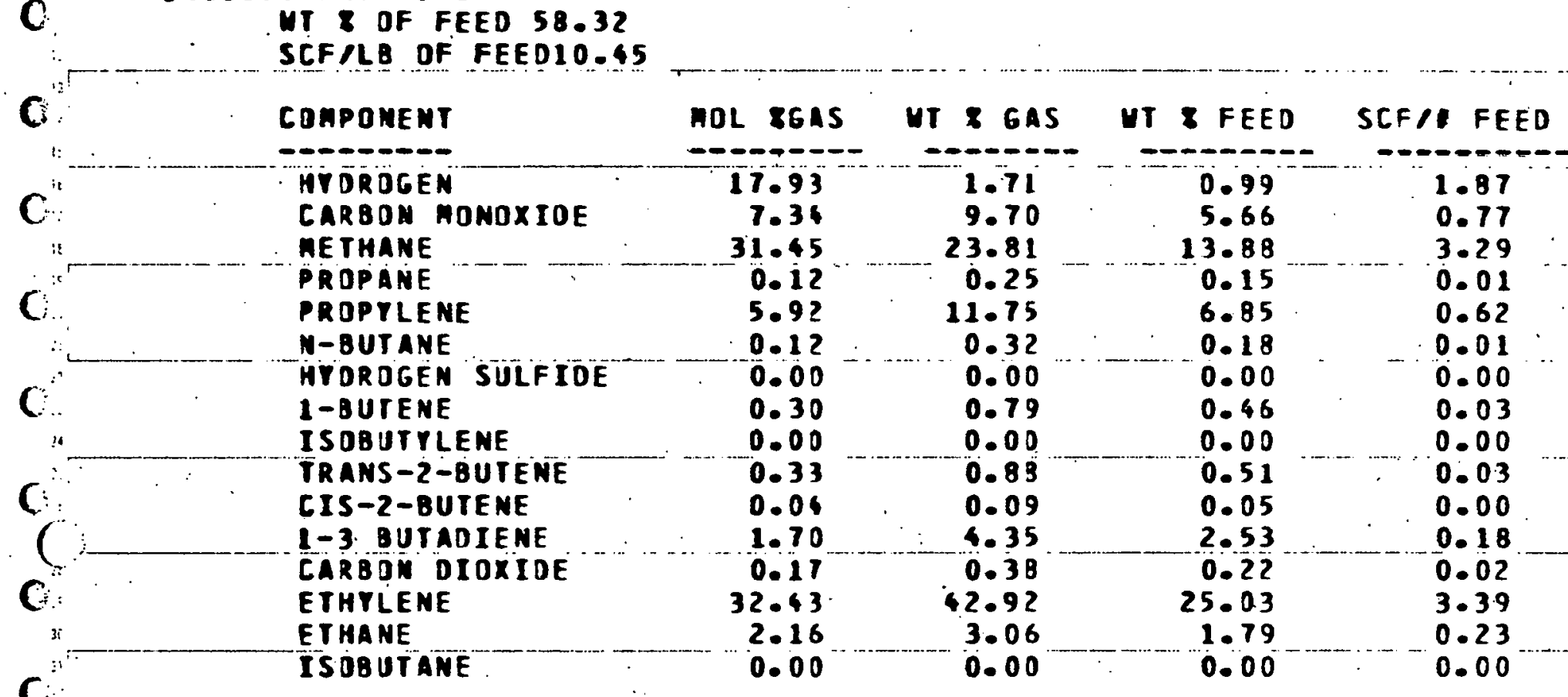

C.

LIQUTD PRODUCTS

UT 8 OF FEED $1 . \overline{6} 8$

C.

SOLIO PRODUCTS

C

WT: OF FEED 0.00

C

$\mathrm{C}$

c.

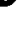

C

C

C 
0

c RUN MUNBER $=M 060178032$

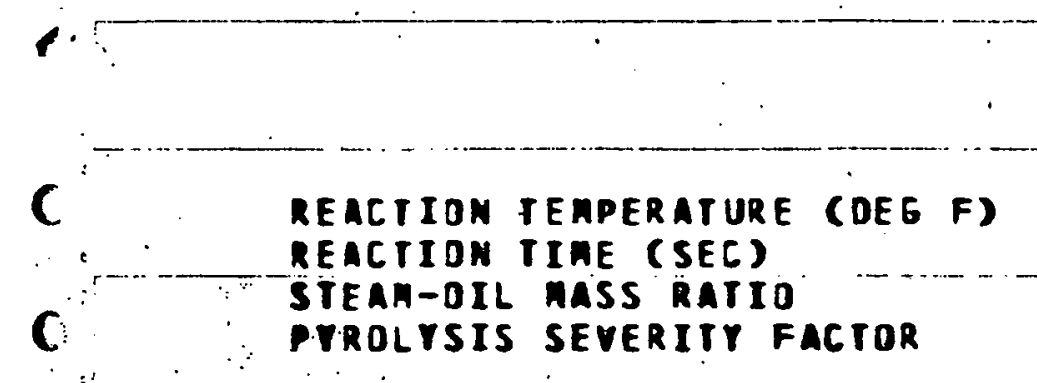

\begin{tabular}{c}
$\max T$ \\
150 \\
\hdashline$-0-2$
\end{tabular}

\begin{tabular}{ccc} 
MAX T & AVE & AVET \\
MONISO & ISO & RDNISO \\
\hline 1311.0 & 1304.6 & 1304.6 \\
0.347 & 0.752 & 0.917 \\
1.149 & 11.769 & 1.149 \\
1301.3 & 1291.4 & 1306.9
\end{tabular}

C

GASEOUS PRODUCTS

YT 8 DF FEED 52.78

SLF/LB OF FEEO 7.65

c

C

COMPONENT

HTOROGEN

CARBON MONOX IOE

METHANE

PROPANE

PRDPTLENE

M-BUTANE

HTDRDGEN SULFIOE

1-BUTE.NE

ISOBUTYLENE

IRANS-2-BUTENE

TIS-2-BUTENE

1-3 BUTADIENE

1371.0

0.722

1.149

1359.8

1301.3

1291.4

1306.9

CARBON DIOXIDE

EIHTLENE

ETHANE

ISOBUTANE

HOL 86AS

13.17

8.65

21.87

0.43

13.83

0.15

0.03

3.57

0.00

0.50

0.22

3.25

0.11

30.96

3.23

0.00

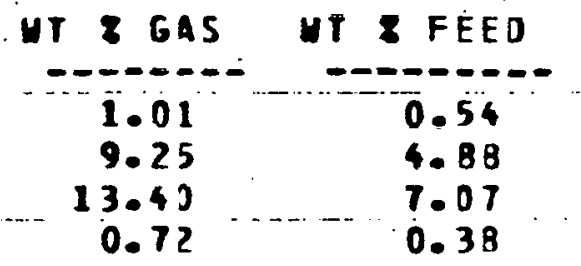

11.73

0.18

0.02

4.06

0.00

0.57

0.25

3.55

0.10

17.50

1.95

0.00
SCFI FEED

1.01

0.66

1.67

0.03

1.0 .6

0.01

0.00

0.27

0.00

0.04

0.02

0.25

0.01

2.37

0.25

0.00

\section{LIQUIO PRDDUCTS}

WT 8 OF FEED,47.22

SOLID PRODUCTS

WTZ OF FEED 0.00 .

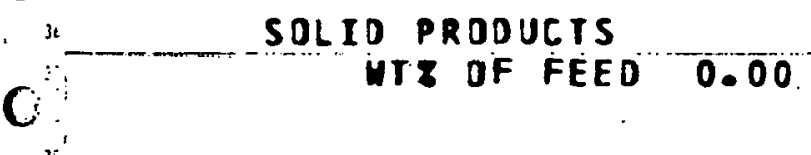

C

$c$

$c$

C

$C$ 
C.

(

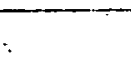

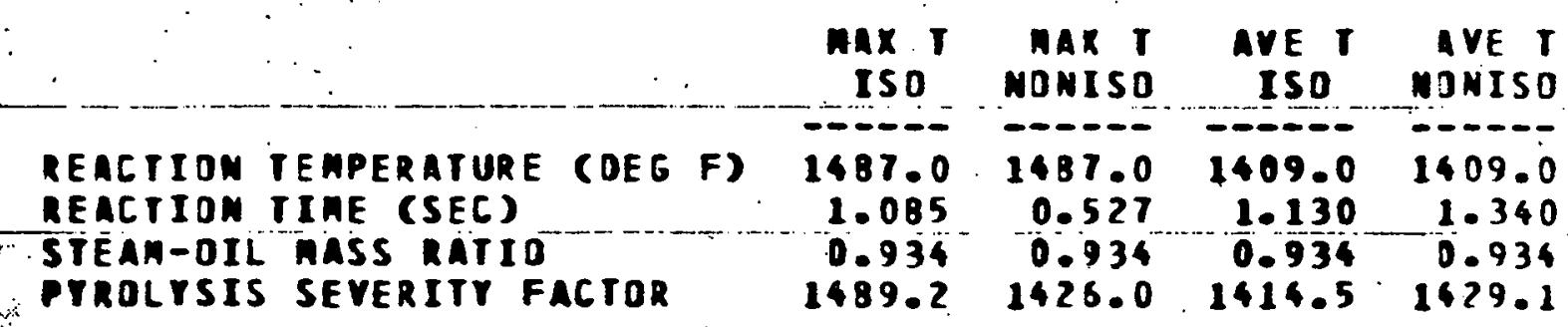

GASEOUS PRODUCTS UT 2 OF FEED 55.72

SLF/LB DF FEED 9.45

CONPONENT

CO--O-D-

HYDRDGEN

CARBON MONOXIDE

METHANE

PRDPANE

PROPYLENE

N-BUTANE

HYDRDGEN SULFIDE

1-BUTENE

ISOBUTYLENE

TRANS-2-BUTENE

CIS-2-BUTENE

1-3 BUTADIEME

CARBOA DIOXIOE.

ETHTLENE

ETHANE

ISOBJTANE
HOL JGAS

18.38

8.00

27.42

0.26

8.73

0.13

0.02

0.85

0.00

0.36

0.03

2.52

0.33

30.34

2.64

0.00

\begin{tabular}{c} 
UT 645 \\
\hline 1.65 \\
10.00 \\
19.64 \\
0.47 \\
16.36 \\
0.34 \\
0.03 \\
2.17 \\
0.00 \\
0.89 \\
0.23 \\
6.09 \\
0.61 \\
38.00 \\
3.54 \\
0.00 \\
\hline
\end{tabular}

0.00

YT FEEO
-0.92
5.57
10.94
0.26
9.11
0.19
0.02
1.21
0.00
0.50
0.13
3.40
0.36
21.17
1.97
0.00

SCFII FEED -D-- - - - -

1.74

0.7 .6

2.59

0.02

0.82

0.01

0.00

0.08

0.00

0.03

0.01

0.24

0.03

2.87

0.25

0.00

\section{LIQUTD PRDDUCTS}

UT OF FEED $\$ 4.28$

C

SOLID PRODUCTS

UT DF FEED 0.00

C

C

c

C:

c

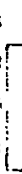

$C^{2}$

C 


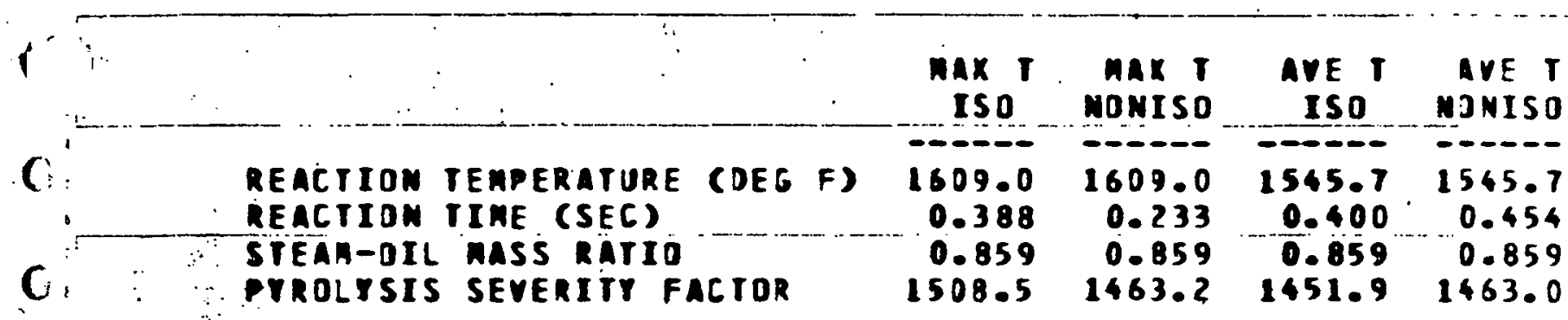

C

\section{SASEOUS PRODUCTS}

VT \& DF FEED 65.49

SCF/LB OF FEEDI1.06

C

COMPOMENT

MOL $86 A S$

COAPOMENT - - -

CARBDN MONOXIDE

14.85

3.82

ME THANE

PRDPANE

31.68

PROPYLENE

0.16

N-BUTANE

7.65

HYDR OGEN SULFIDE

0.21

1-BUTENE

0.00

IS DBUTYLENE

0.54

TRANS-2-BUTÉNE

0.00

CIS-2-BUTENE

0.45

1-3 BUTADIENE

CARBON DIOXIDE

ETHYLENE

ETHANE

ISOB UTANAE

0.05

2.33

0.11

36.15

2.16

0.00

0 GAS
0.073
1.33
4.75
22.61
0.31
13.97
0.55
0.00
1.36
0.00
1.16
0.13
5.61
0.23
45.11
2.88
0.00

4 T FEEO

0.37

3.12

14.81

0.20

9.15

0.36

0.00

0.89

0.00

0.75

0.09

3.67

0.15

29.54

1.89

0.00

SCF/ FEED

1.64

0.42

3.51

0.02

0.83

0.02

0.00

0.06

0.00

0.05

0.01

0.26

0.01

4.00

0.24

0.00

\section{LIRUID PRODUCTS}

WT $\&$ OF FEED 34.51

SOLIO PROOUCTS

C

WTE OF FEED 0.00

C

C

C

C

C

C 


\section{C

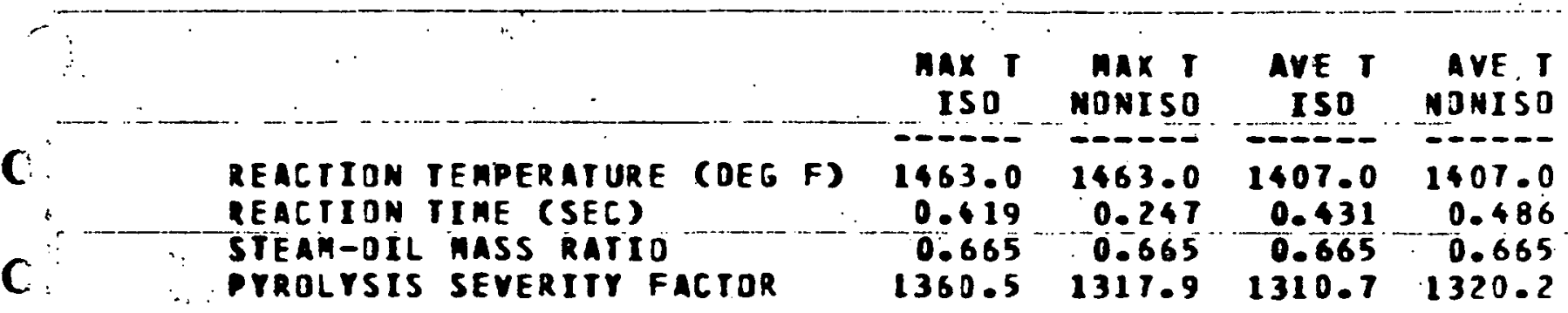

C. GASEOUS PRODUCTS

UT $\&$ OF FEED 61.70

SEFILB OF FEED 9.36

C.

CONPONENT

MOL SEAS

HYOROGEN

C

CARBON MONOXIDE $--2--0 .-$.

$4 T$ GAS

UT $\&$ FEED SCF/E FEED

METHANE

3.99

1.04

$\therefore--2=--1$

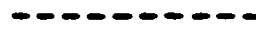

PROPANE

PROPYLENE

$26.9 ?$

4.47

17.25

0.40

0.71

12.13

- N-BUTANE

0.19

20.39

MTDROGEN SULLIDE

0.00

0.44

0.00

2.13

4.78

ISOBUT YLENE

0.00

0.00

0.49

1.08

0.19

CIS-2-BUTENE

3.52

0.40

1-3 BUTADIENE

7.60

0.04

ETHYLENE

ETHANE

33.77

ISOBUTAN̈E

3.29

0.00

0.07

37.83

3.95

0.00

0.66

2.76

i. 21

10.64

0.44

12.58

0.27

0.00

2.95

0.00

0.66

0.24

4.69

0.04

23.35

2.44

0.00
0.37

2.52

0.04

1.13

0.02

0.00

0.20

0.00

0.04

0.02

0.33

0.00

3.16

0.31

0.00

C

LIPUID PRDOUCTS

IT \& OF FEED $38 . \overline{30}$

C:

SOLIO PRODUCTS

C

WT DF FEED 0.00

C

C

C.

C 


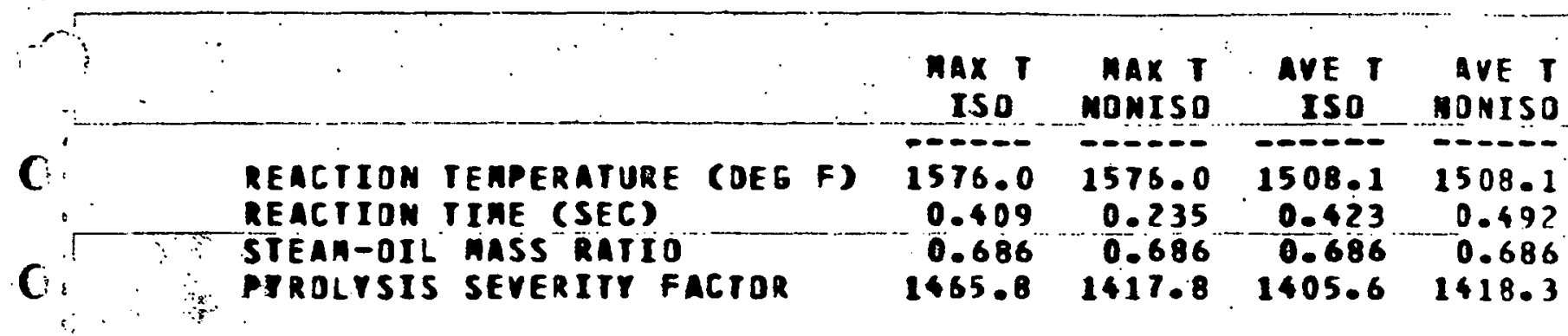

$C$

GASEOUS PROOUCTS

YT 2 DF FEED 64.32

SCF/LB OF FEED 10.75

C

COMPONENT

HTOROGEN

CARBON MONOXIDE

METHANE

PROPAME

PROPYLENE

M-BUTANE

HYDROGEN SOLFIDE

1-BUTENE

ISDBUT TLENE

TRANS-2-BUTEME

CIS-2-BUTENE

1-3 BUTADIENE

CARBOA DIOXIOE

ETHYLENE

ETHANE

IS OBUTANE

MOL SGAS

UT 2 GAS

15.63

3.49

30.20

0.21

8.50

0.18

0.00

0.69

0.00

1.39

4.28

21.32

0.42

15.75

0.47

0.00

1.71

0.00

0.45

1.12

0.07

2.66

0.18

6.33

0.09

0.13

35.35

2.43

43.68

3.21

0.00

0.00

UT $₹$ FEED

SCF / FEED

$$
0.39
$$

1.69

0.37

3.25

0.02

0.91

0.02

0.00

0.07

0.00

0.05

0.01

0.29

0.01

3.80

0.26

0.00

LIQUID PRDDUCTS

UT OF FEED 35.68

SOLID PRODUCTS

UT OF FEED 0.00 


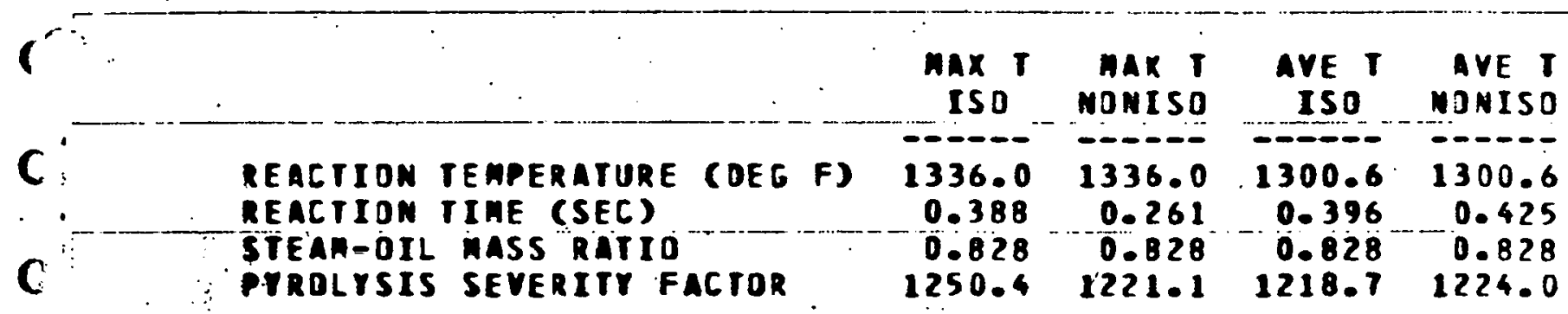

$C$ GASEDUS PRODUCTS

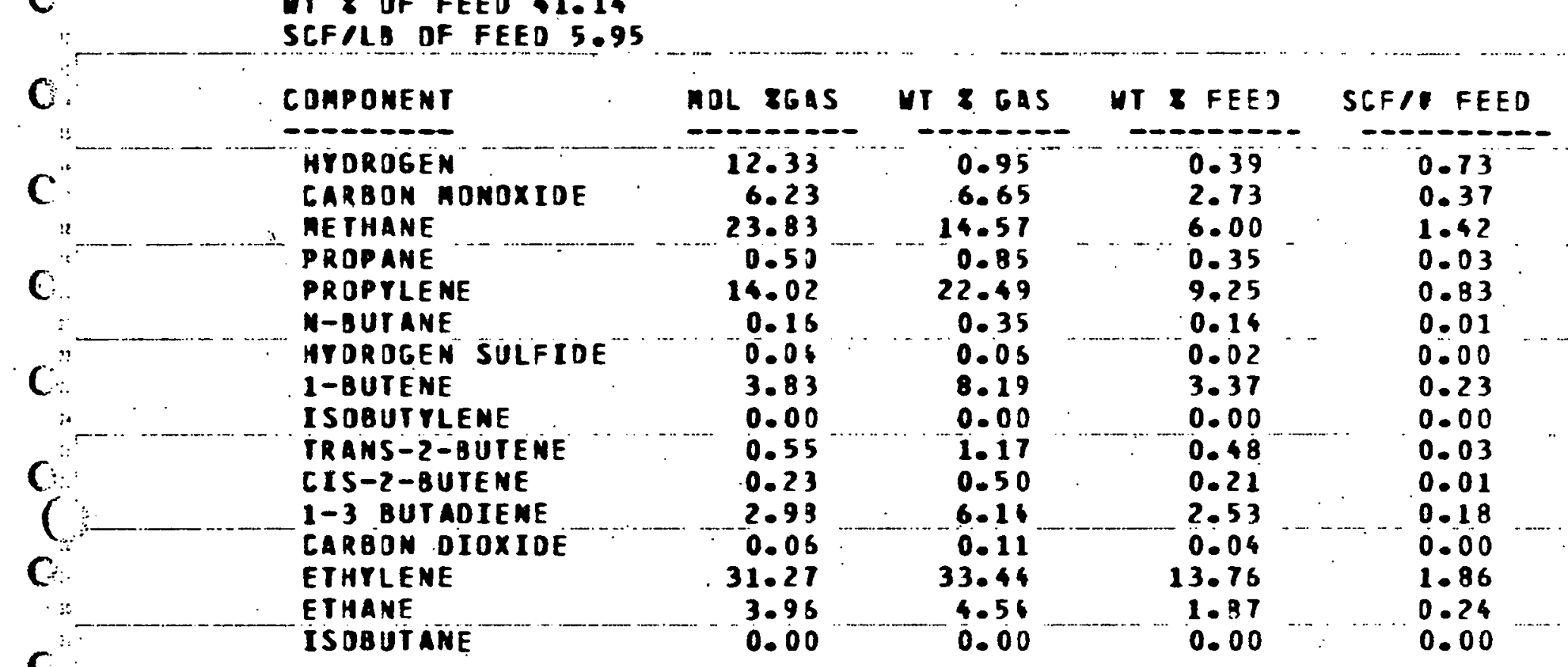

C

LIQUID PRODUCTS

C
UT OF FEED 58.86
SOLID PRODUCTS
UTE DF FEED 0.00
\begin{tabular}{l} 
SOLID PRODUCTS \\
MTE DF FEED \\
\hline
\end{tabular}

C

$\mathrm{C}$

C

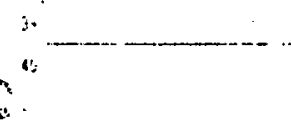

$C$

C

si:

Con 
(

C

C

e

c

C

C

C

C

C

C

C.

$\mathrm{C}$

c

c

C

(

\begin{tabular}{|c|c|c|c|c|c|c|c|}
\hline & & & & $\begin{array}{c}\max 1 \\
\text { ISO }\end{array}$ & $\begin{array}{c}\max \mathbf{T} \\
\text { MONISO }\end{array}$ & $\begin{array}{l}\text { AVE T } \\
\text { ISO }\end{array}$ & $\begin{array}{r}\text { IVE T } \\
\text { MONISO }\end{array}$ \\
\hline A & $\begin{array}{l}\text { TIME (SEC) } \\
\text { MASS RATIO } \\
\text { SEVERITY F }\end{array}$ & CDE G & & $\begin{array}{r}1590.0 \\
0.769 \\
0.722 \\
1539.9\end{array}$ & $\begin{array}{r}1590.0 \\
0.408 \\
0.722 \\
1482.4\end{array}$ & $\begin{array}{r}1510.9 \\
0.800 \\
-0.722 \\
1466.7\end{array}$ & $\begin{array}{r}1510.9 \\
0.960 \\
0.722 \\
1482.9\end{array}$ \\
\hline
\end{tabular}

GASEOUS PRODUCTS

UT OF FEED 79.77

SCF/LB OF FEED15.64

COMPONENT

HYOROGEN

CARBON MONOXIOE

NETHANE

PROPANE

PROPTLENE

H-BUTANE

HTOROGEN SULFIDE

1-BUTENE

ISOBUTYLENE

TRANS-2-BUTENE

CIS-2-BUTENE

1-3 DUTADIENE

CARBON DIOXIDE

ETHYLENE

ETHANE

I SOB UTANE
HOL $8 G A S$ HT 2 GAS

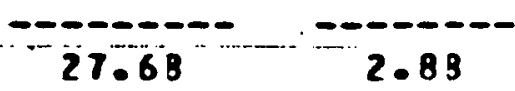

15.15

24.16

0.12

4.70

0.09

0.00

0.33

0.00

0.22

0.04

1.35

0.93

23.39

1.82

0.00
21.90

20.01

0.28

10.20

0.28

0.00

0.96

0.00

0.65

0.12

3.79

2.22

$33.8 \mathrm{~B}$

2.83

0.00
UT $\&$ FEED

$=-\frac{2 .-0-}{2.30}$

17.47

15.96

0.22

8.14

0.22

0.00

0.77

0.00

0.52

0.10

3.03

1.77

27.02

2.25

0.00
SCF/E FEED

4.33

2.37

3.78

0.02

0.73

0.01

0.00

0.05

0.00

0.04

0.01

0.21

0.15

3.66

0.28

0.00

\section{LIRUID PRODUCTS}

UT $Z$ OF FEED 20.23

SOLIO PRODUCTS

HT ÖF FEED 0.00 
$\ddot{c}$

$C$

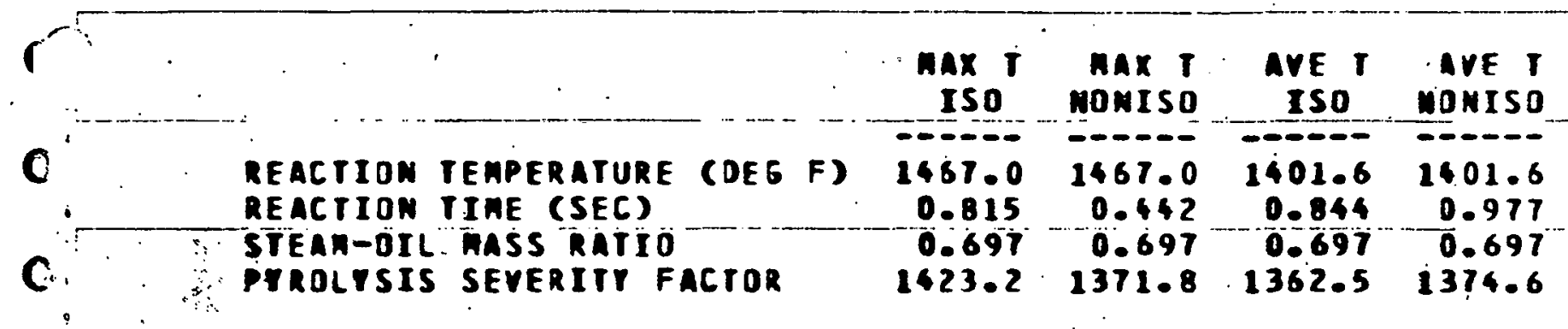

C GASEOUS PROOÜCTS

SCFILB OF FEED 9.53

C

C

COMPONENT

HYOROGEN

C

CARBON MONOXIDE

ME THANE

Propane

PROPTLENe

M-BUTANE.

HTDROGEN SULFIDE

1-BUTENE

ISOBUTRLENE

TRANS-2-BUTENE

CIS-2-BUTENE

1-3. BUTADIENE.

CARBON DIOXIDE

ETHYLENE

ETHANE

ISOBUTANE

MOL ZGAS, UT I GAS WT I FEED SCF/I FEED

C

$\mathrm{C}$

c

LIPUID PRODUCTS

WT 2 OF FEED 38.68

SOLID PRODUCTS

C. WTZ DF FEED 0.00

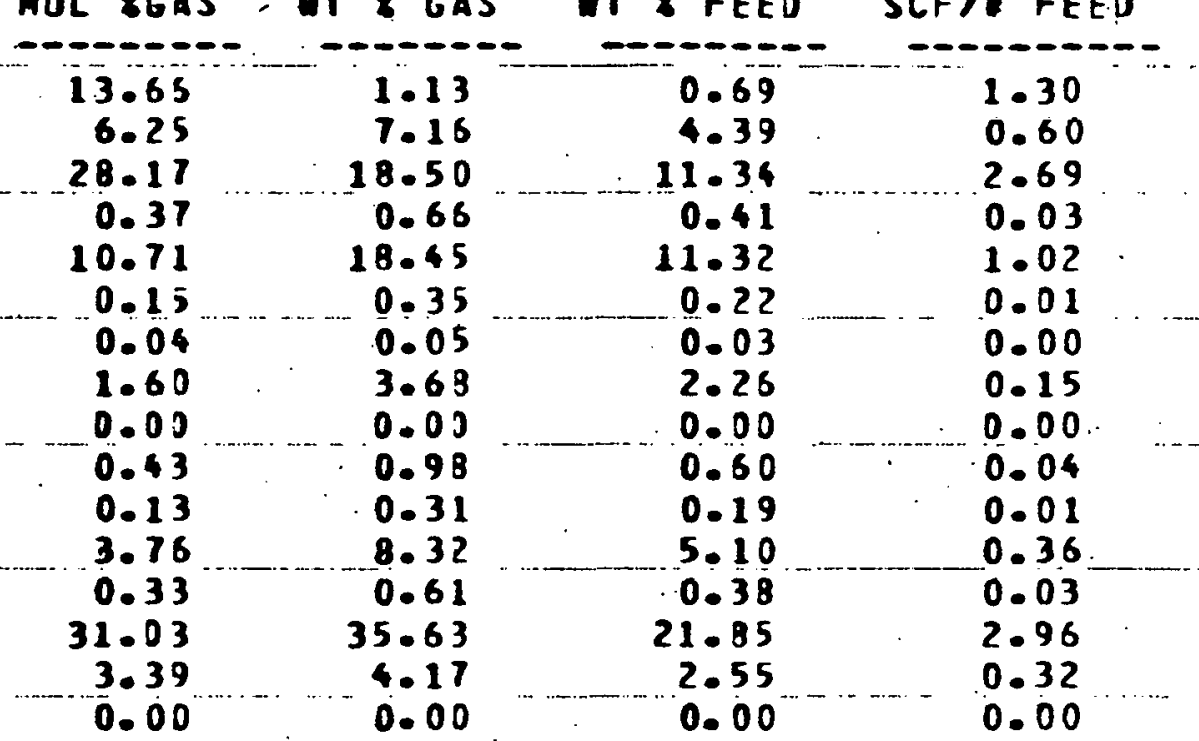

$c$

$\mathrm{C}$

c

C

$C^{\prime \prime}$ 
0

c. RUN MUNBER $=$ HO61618060

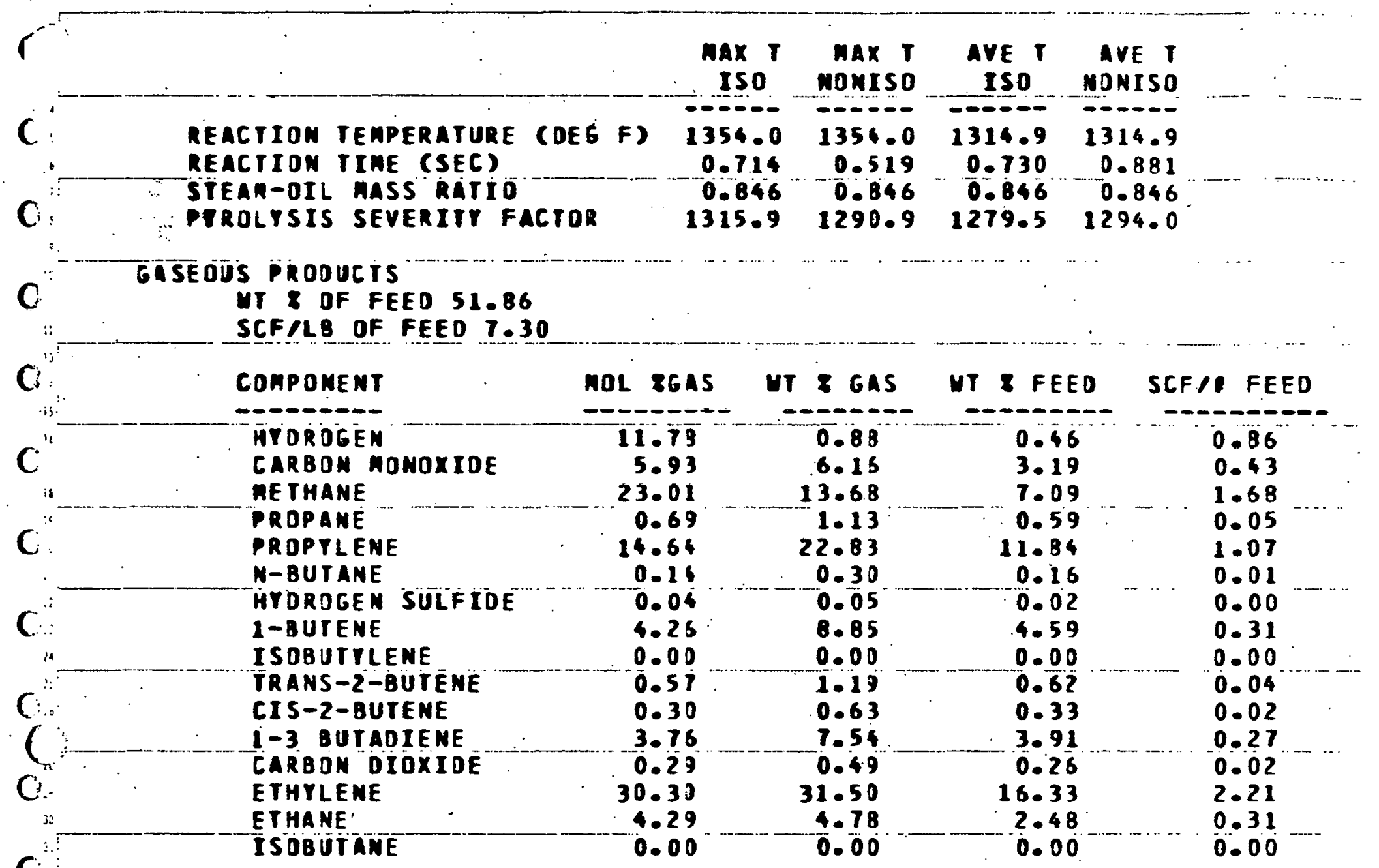

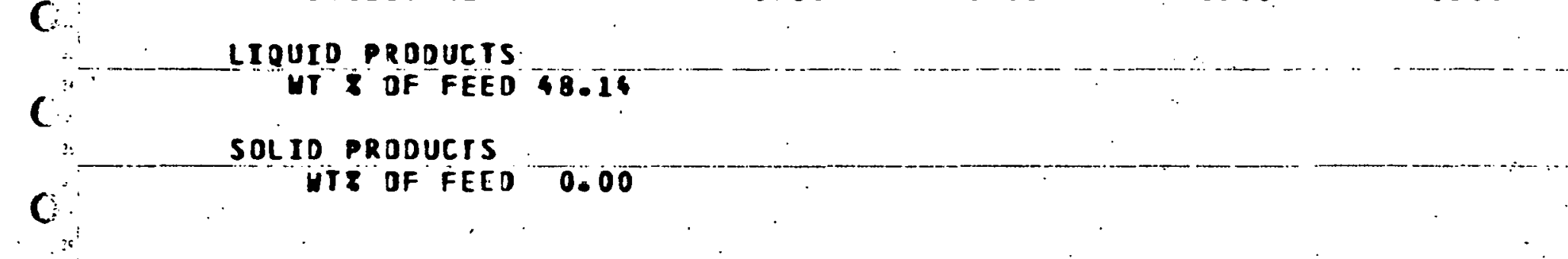

C

C

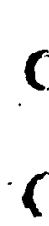

LIQUID PRDDUCTS
UT OF FEED 48.18

SOLID PRODUCTS

WT OF FEED 0.00 


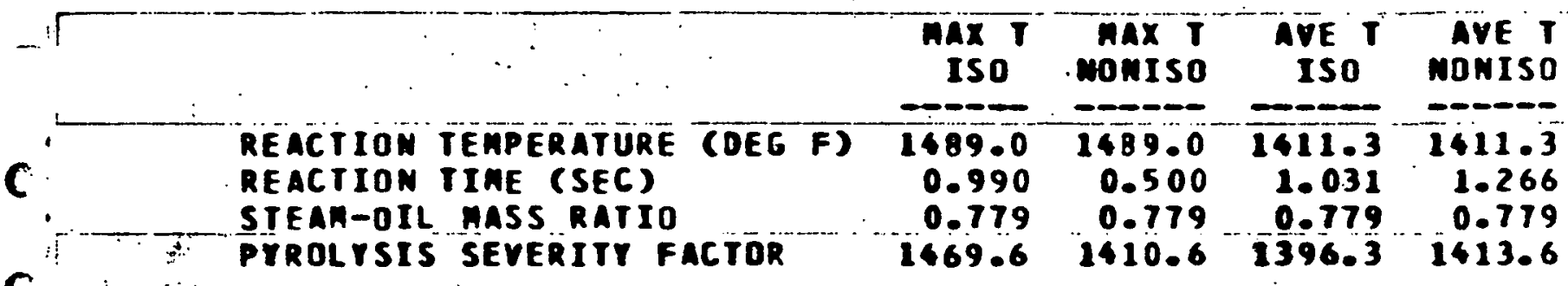

C CASEDUS PROOUCTS

C UT 8 OF FEED 70.84

UT 8 OF FEED 70.84
SCFILB OF FEED 11.15

C

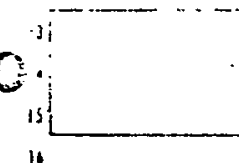

COMPONENT

HYDROGEK

c

CARBON MONOXTOE

METHANE

PROPANE

PROPTLENE

N-BUTANE

HTOROGEN SULFIOE

1-BUTENE

ISOBUTYLENE

TRANS-2-BUTENE

C.

CIS-2-BUTENE

1-3 BUTADIENE

CARBOA DIOXIDE

ETHYLENE

ETHANE

ISOBUTANE

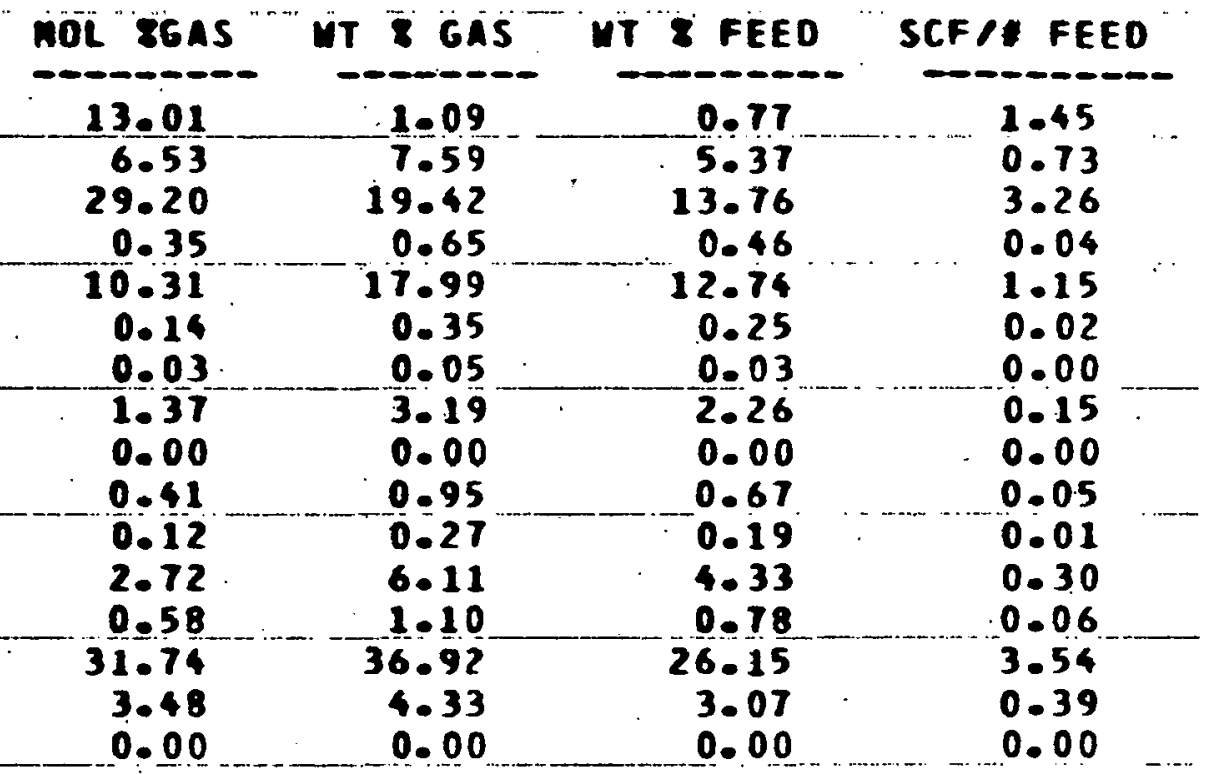

C

$+$

E

LIQUID PRODUCTS

HT 8 OF FEED 29.16

$c$

SOLID PRODUCTS

HT OF FEED 0.00

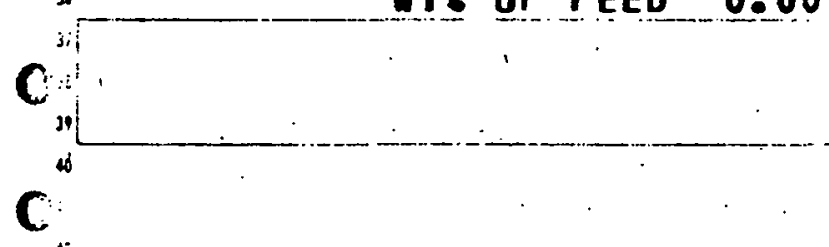

0

c

$c$

.

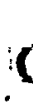

$C$ 
C

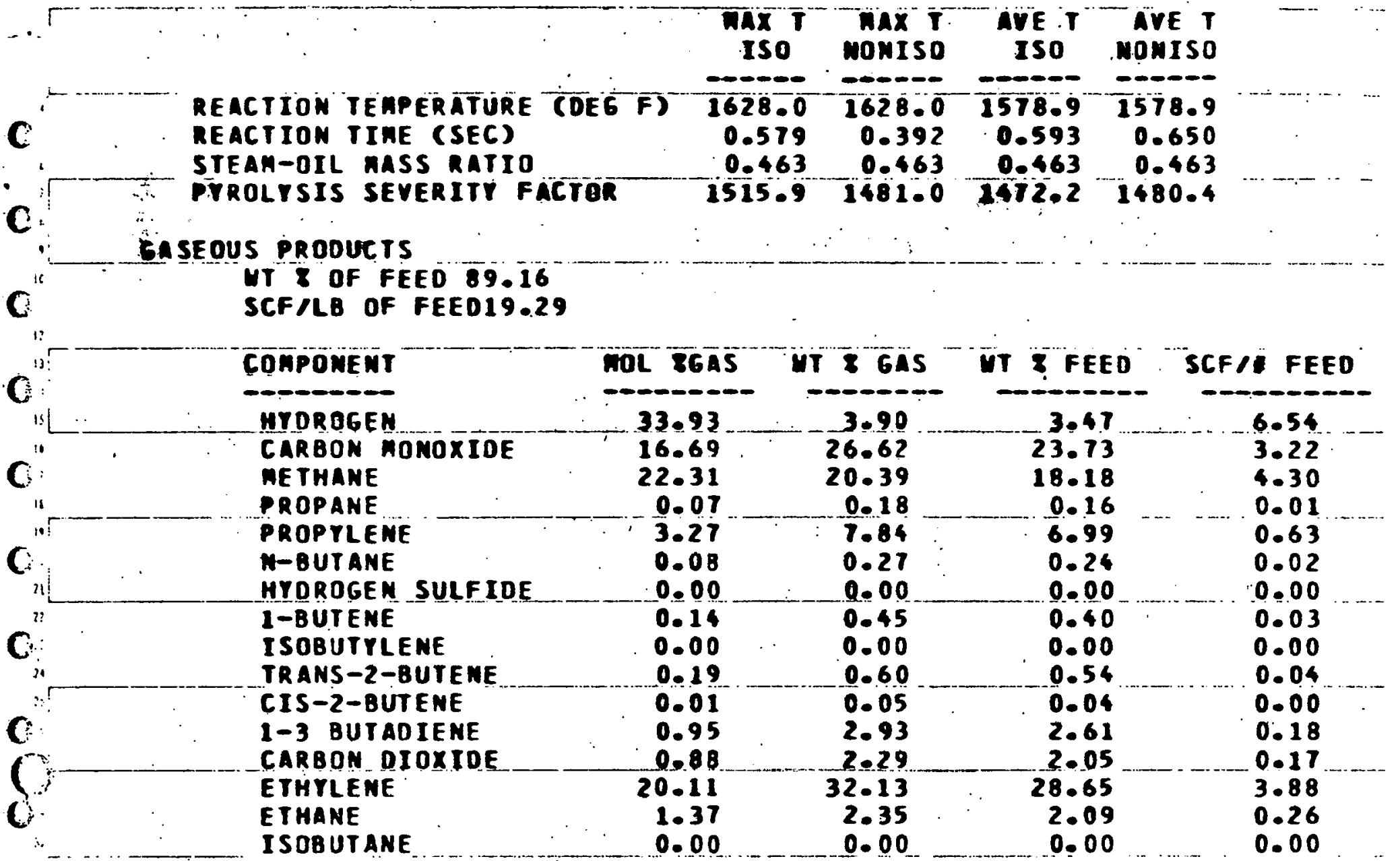

$c$

LIQUID PRODUCTS

WT $I$ OF FEED 10.84

C. SOLIO PRODUCTS

UT 8 OF FEED 0.00

$C$

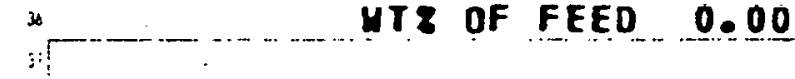

C

6

c

O

$\stackrel{3}{3}$

C

Cis 


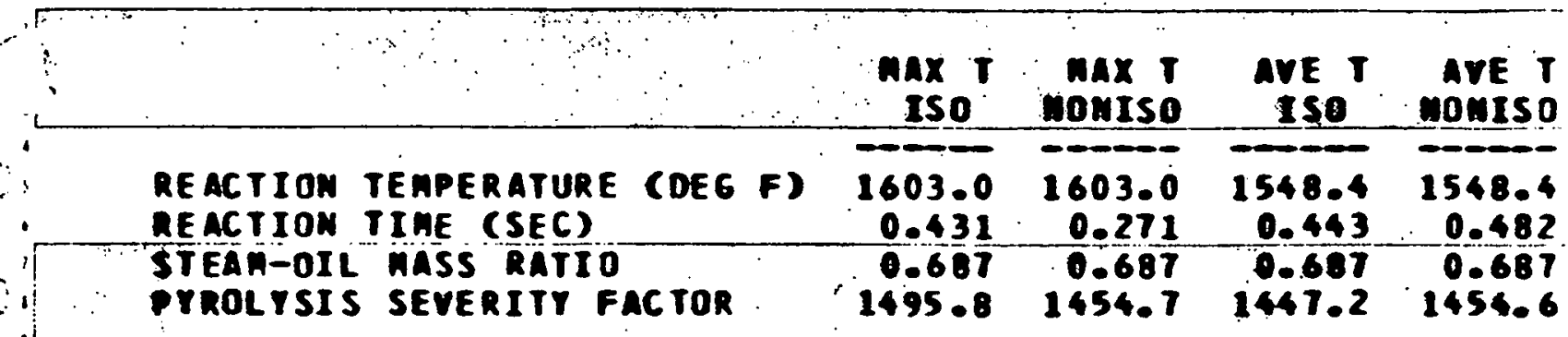

C. GASEOUS PRODUCTS

SCFILB OF FEED20.34

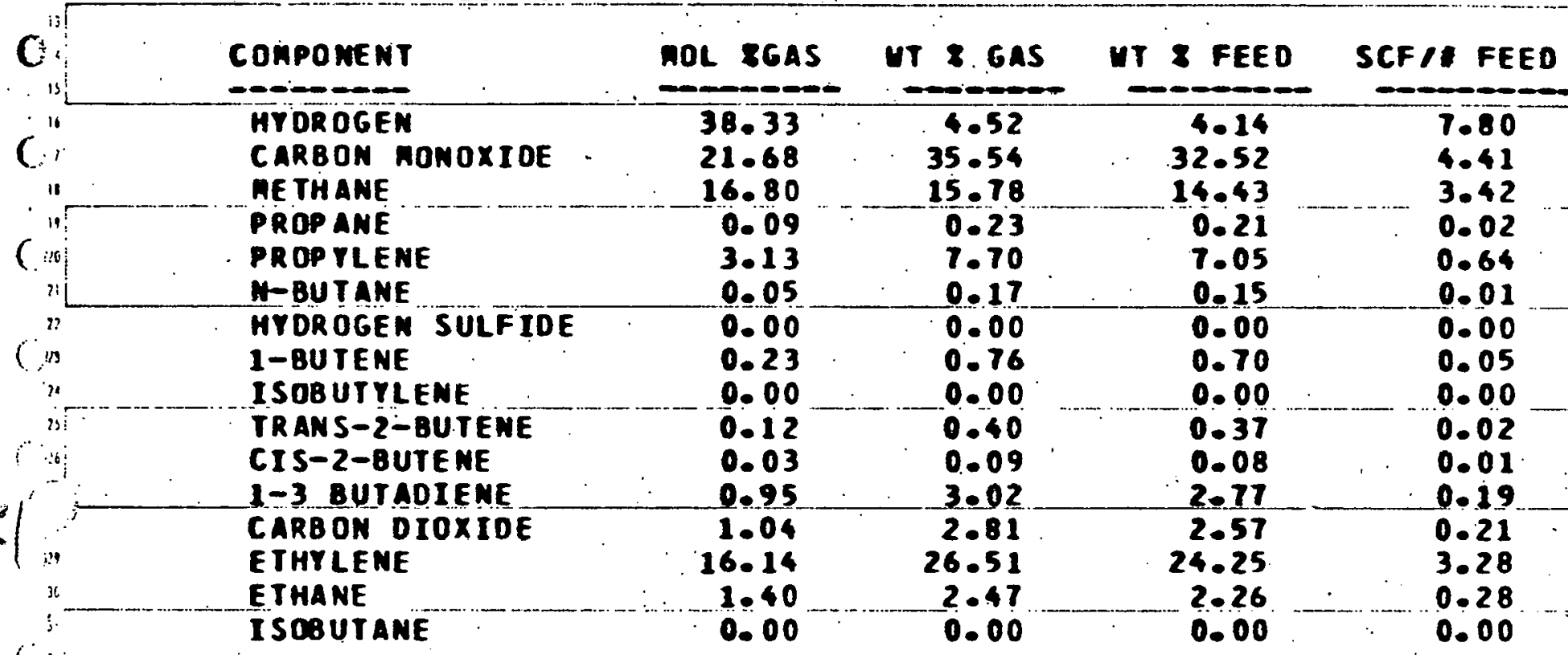

LIQUID PRODUCTS

WT 8 OF FEED 8.51

$(3$

* SOLIO PRODUCTS

WI OF FEED 0.00

Cos

c.

$c$

c

C.

0
31
3

$\overline{\mathbf{C}}$

$C$

( ) 


\begin{tabular}{|c|c|c|c|c|c|c|c|}
\hline $8 \mathrm{fi}$ & $1 \%$ & $\therefore$ & & $\begin{array}{l}\max T \\
\end{array}$ & $\begin{array}{r}\max T \\
\text { NONISO }\end{array}$ & $\begin{array}{l}\text { AYE T } \\
\text { ISO }\end{array}$ & $\begin{array}{r}\text { AVE } T \\
\text { MONISO }\end{array}$ \\
\hline 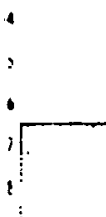 & $\begin{array}{l}\text { REACTION } \\
\text { REACTION } \\
\text { STEAR-OIL } \\
\text { PTROLYSIS }\end{array}$ & $\begin{array}{l}\text { TEMPERATURE COEG } \\
\text { IIAE (SEC) } \\
\text { AASS RATIO } \\
\text { SEVERITY FACTOR }\end{array}$ & F) & $\begin{array}{r}1576.0 \\
0.388 \\
0.730 \\
1465.7\end{array}$ & $\begin{array}{r}1576.0 \\
0.220 \\
0.730 \\
1416.7\end{array}$ & $\begin{array}{r}1508.6 \\
0.401 \\
0.730 \\
1405.9\end{array}$ & $\begin{array}{r}1508.6 \\
0.459 \\
0.730 \\
1417.2\end{array}$ \\
\hline
\end{tabular}

$C$ GASEOUS PRODUCTS
ST 8 OF FEED 59.83
SCF $\triangle$ B OF FEED 9.61

C

ST: SCFAB OF FEED 9.61

C

$--O---$

NOL $26 A S$ UT 8 GAS UT \& FEED SCF/E FEED

HYDR OGEN

$-\frac{10}{11.79}-\frac{810}{1.01}$

- $-----O-1$ $-------$

CARBON MONOXIDE

4.13

4.89

METHANE

PROP ANE

32.04

21.74

0.60

1.13

PROPYLENE

0.24

0.45

2.92

0.40

N-BUTANE

8.88

HTDROGEN SULFIDE

0.19

15.80

13.01

3.08

0.00

0.47

0.27

0.02

1-BUTENE

0.80

0.00

9.45

0.85

ISOBUT ILENE

0.00

1.90

0.00

0.02

TRANS-2-8UTERE

0.47

0.00

1.14

0.00

CIS-2-BUTENE

0.08

1-3 BUTADIENE

2.64

$1 \cdot 11$

0.00

0.08

CARBON DIOXIOE

0.26

0.20

6.03

0.66

0.00

ETHYLENE

ETHANE

I SOBUTAME

35.61

0.51

0.12

0.04

0.01

0.25

3.61

0.02

2.87

42.25

0.30

3.42

0.00

3.65

25.28

0.28

2.18

0.00

LIOUIO PRODUCIS

UT $I$ OF FEED 40.17

C.

SOLID PRODUCTS

C

UT: OF FEED 0.00

C.

C.

C.

C.

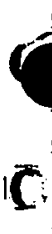

C

YTS OF FEED O.00 


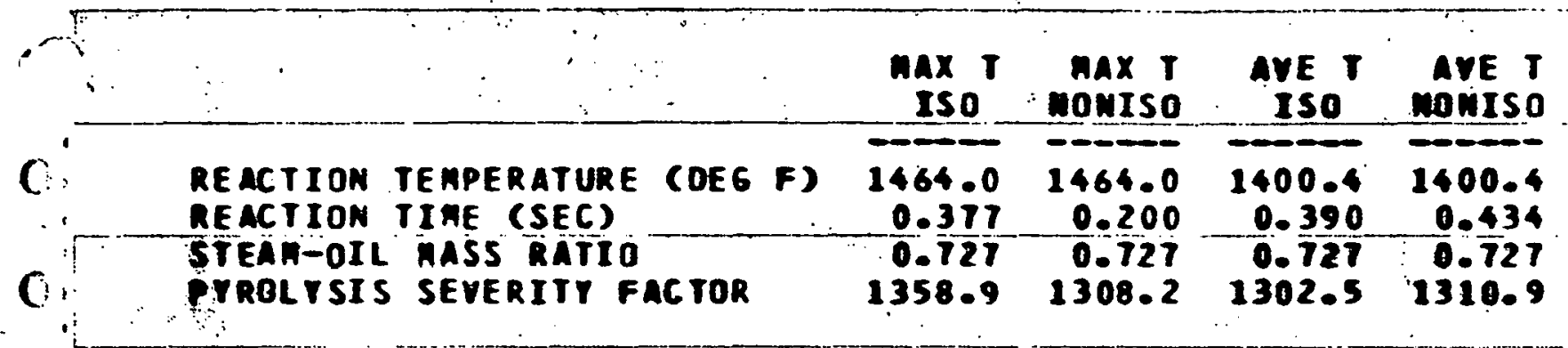

C." GASEOUS PRODUCTS

SCFAB OF FEED 8.65

C

COMPONENT

HOL 8643

HYOROGEN

$--$

पT 8 6AS

UT 8 FEED

SCF/ FEED

CARBON MONOXIDE

METHANE

PROPANE

PROP TLENE

H-BUTANE

9.46

$=-\frac{20}{0.72}$

$=-$

3.54

26.42

3.73

2.26

0.45

15.98

9.66

13.47

HYOR OGEN SULFIDE

0.18

0.75

0.45

$21 \cdot 37$

0.00

0.40

12.92

0.24

1-BUTENE

2.85

I SOB UT YLENE

TRANS-2-BUTENE

0.00

0.00

0.00

3.65

$0: 00$

0.00

0.53

CIS-2-BUTE AE

0.20

1-3 BUTADIENE

CARBON DIOXIDE

ETHTLENE

ETHANE

I SOBUTAME

3.75

0.26

35.57

3.31

1.13

0.68

0.43

7.66

0.45

0.26

4.63

37.61

0.27

3.76

22.74

2.27

0.00

0.82

0.31

2.29

0.04

1.17

0.02

0.00

0.25

0.00

0.05

0.02

0.32

0.02

3.08

0.29

0.00

0.00

0.00

LIOUID PROOUCTS

C.

UT 8 OF 


\section{RUN MUOER dipor3704t'}

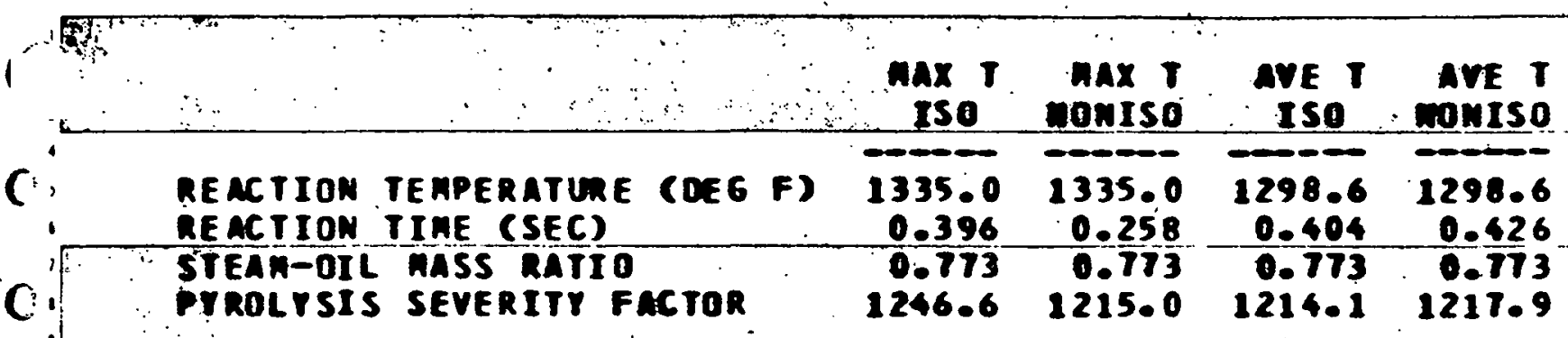

10 GaseOUS PRODUCTS

$C: 11$ UT OF FEED 41.48
SCF L B OF FEED 5.82

C

COAPONENT

C

ATOR OGEM

CARBON MONOXIOE

PRTHANE

C.

PROP TLEME

N-BUTANE

HYDR OGEN SULFIOE

1-BUTENE

ISOBUTYLENE

C

TRANS-2-BUTENE

CIS-2-BUTENE

1-3 BUTAOIENE

CARBON DIOXIDE

ETHTLENE

ETHANE

ISOB UTANE

HOL EGAS UT 8 GAS UT 3 FEED SCF/IFEED

$\begin{array}{rrr}8.51 & 0.63 & -1 \\ 3.11 & 3.22 & 0.26 \\ 26.13 & 15.49 & 1.34 \\ 0.543\end{array}$

0.26

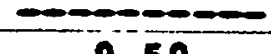

0.55

0.90

6.43

0.18

14.77

0.22

22.97

0.00

0.47

3.48

0.00

0.00

7.22

0.00

0.56

1.15

0.24

0.50

3.17

6.34

0.19

35.12

3.95

0.32

36.40

4.39

0.00

0.00

0.37

1.52

0.03

9.53

0.86

0.19

0.01

0.00

0.00

3.00

0.20

0.00

0.00

0.03

0.48

0.01

2.63

0.18

0.13

0.01

2.04

0.23

1.82

0.00

LIOUTD PRODUCTS

UT $\&$ OF FEED 58.52

C. 3

$\sqrt[3]{\text { SOLID PRODUCTS }}$

C

SOLID PRODUCTS 


\section{HUN MUNEER = MO6267004T}

C.

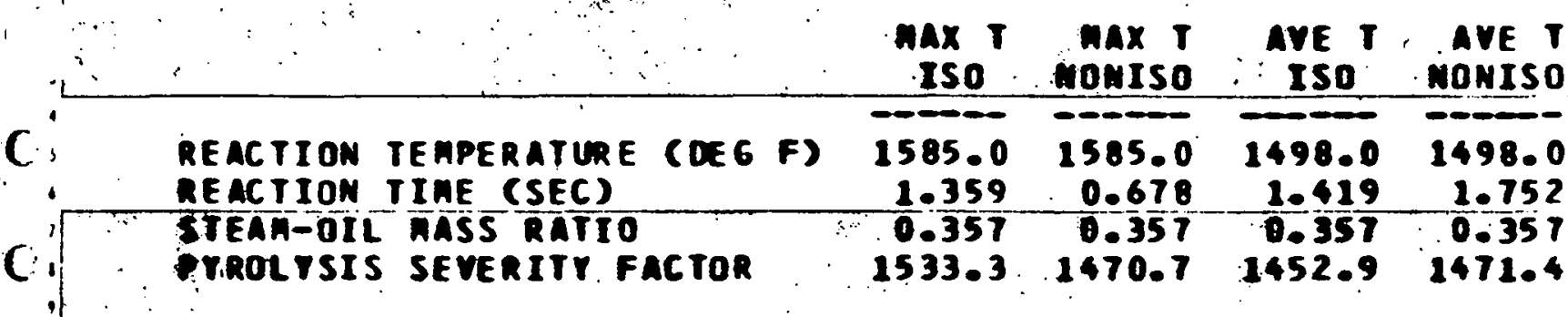

C" GASEOUS PRODUCTS

CUT $\$$ OF FEED 60.93
SCFALB OF FEED 10.64

C

COMPONENT

nol $36 a$

MTOROGEN

C.

CARB ON MONOXIDE

-

METHANE

PROP ANE

PR OP YLENE

M-BUTANE

HYDROGEN SULFIDE

14.21

7.49

UT 2 GAS

UT 8 FEED

SCF/ FEED

1-BUTENE

ISOBUTYLENE

TRAN S-2-8UTENE

34.95

1.32

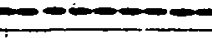

0.13

9.65

5.88

1.51

0.80

25.79

15.71

3.72

5.85

0.08

0.25

0.15

$11 \cdot 32$

6.90

0.01

0.00

0.21

0.13

0.62

C

CIS-2-BUTENE

0.37

0.00

0.00

0.01

0.00

0.95

0.58

0.00

0.26

0.00

0.00

0.04

1-3 BUTAOIENE

0.05

0.68

0.41

0.00

CARBON DIOXIDE

1. 59

0.12

0.07

0.03

ETHYLENE

0.38

3.94

2. 40

0.01

ETHANE

32.01

0.81

0.49

0.17

ISOBUTANE

2.64

$41 \cdot 30$

$25 \cdot 17$

0.04

0.00

$2 \cdot 23$

3.41

0.28

C:3i

LIQUIO PRODUCTS

UT $\$$ OF FEED 39.07

(

SOLID PRODUCTS

UTI OF FEED 0.00 


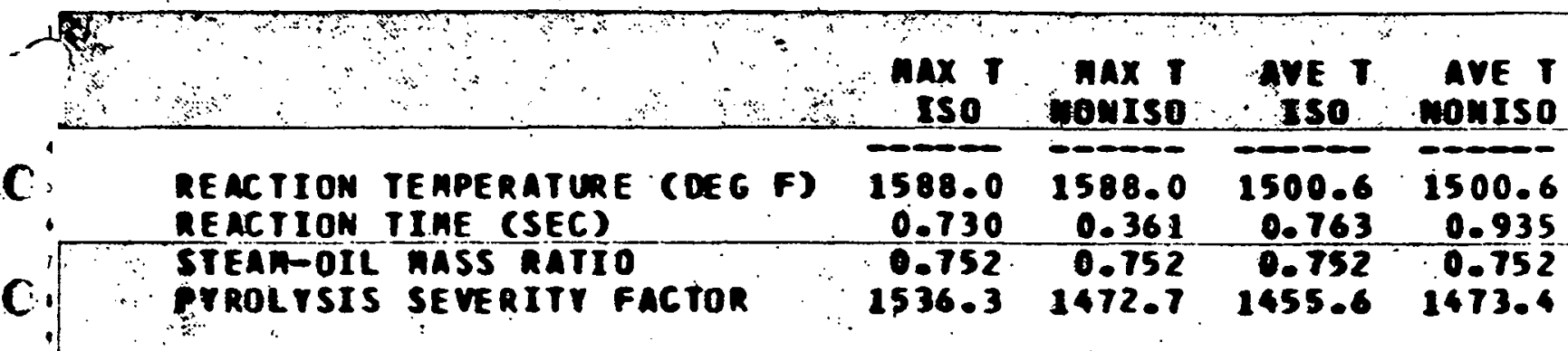

i" GASEOUS PRODUCTS
UT $\$$ OF FEED 60.41

SCFAR OF FEED10:26

C

C.

COMPONENT

MOL RGAS UT 2 GAS

YT $\$$ FEED

SCF/ FEED

MTOROGEN

14.08

1.27

$-\infty-\infty-\infty$

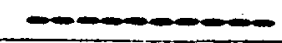

CARBON MONOXIOE

7.43

METHANE

PROP ANE

32.81

9.31

0.19

23.55

0.77

1.45

PROP TLENE

6.79

N-BUTANE

0.12

0.37

5.63

0.76

HYDROGEN SULFIDE

0.00

1-BUTENE

0.55

$12 \cdot 78$

14.22

3.37

0.22

0.02

7.72

0.70

0.19

0.01

ISOB UT TLENE

0.00

0.32

0.00

0.00

0.35

1.37

0.83

0.06

TRANS-2-BUTENE

0.05

$1-3$ BUTADIENE

CARBDN DIOXIDE

1.99

.0 .31

ETHYLENE

ETHANE

ISOB UTANE

32.85

2.48

0.00

0.00

0.00

0.53

0.04

0.14

4.83

0.08

2. 22

0.01

0.39

0.20

0.64

0.03

24.91

3.37

0.00

$3 \cdot 33$

2.01

0.25

C.

LIOUIO PRODUCTS

H HT 3 OF FEED 39.59

Cij)

S SOLID PRODUCTS

C UT $\&$ OF FEED 0.00

C.

C.

$C$

C

.

C

32

C 


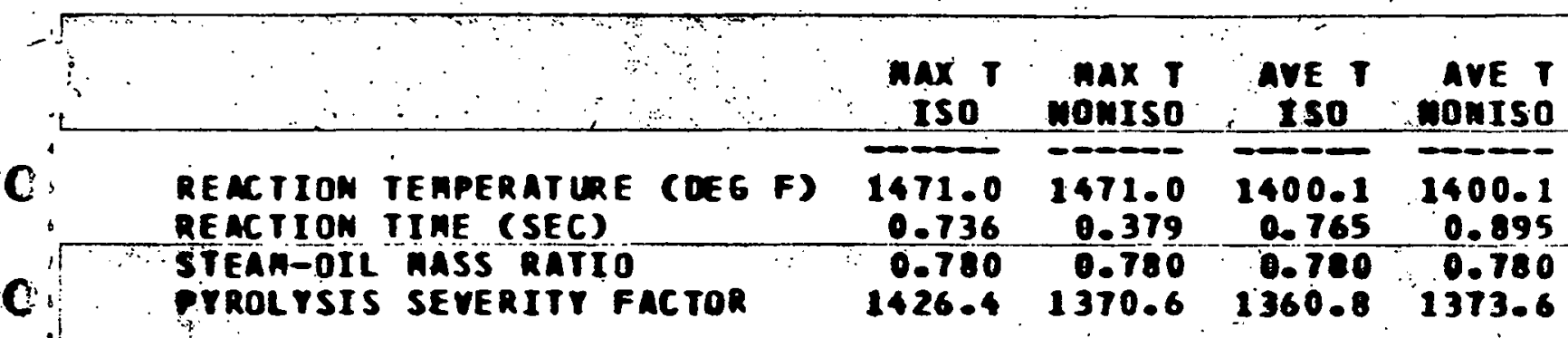

c. GASEOUS PRODUCTS

C UT $\$$ OF FEED 55.84

SCF $2 B$ OF FEED 8.66

Cis: COMPONEnT

HTDROGEN

C

CARBON MONOXIDE

RETHANE

PROP ANE

PROP YLENE

M-BUTANE

HYOROGEN SULFIDE

1-BUTENE

I SOBUT TLENE

TRAN S-2-BUTENE

CIS-2-BUTENE

1-3 BUTAOIENE

CARBON DIOXIDE

ETHYLENE

ETHANE

ISOB UTANE

nOL z6AS

UT 8 GAS

UT 8 FEED

SCFPE FEED

$\begin{array}{rr}13.70 & 1.13 \\ 9.10 & 10.40 \\ 26.14 & 17.11 \\ 0.36 & 0.65 \\ 10.87 & 18.67 \\ 0.16 & 0.38 \\ 0.02 & 0.03 \\ 1.70 & 3.90 \\ 0.00 & 0.00 \\ 0.44 & 1.01 \\ 0.15 & 0.34 \\ 2.84 & 6.26 \\ 0.43 & 0.81 \\ 30.80 & 35.26 \\ 3.30 & 4.04 \\ 0.00 & 0.00\end{array}$

0.63

5.81

9.56

0.36

10.43

0.21

0.02

2.18

0.00

0.56

0.19

3.50

0.45

19.69

2.26

0.00

1.19

0.79

2.26

0.03

0.94

0.01

0.00

0.15

0.00

0.04

0.01

0.25

0.04

2.67

0.29

0.00

C.

LIOUID PRODUCTS

HT 8 OF FEED 44.16

(i)

SOLID PR ODUCTS

UTZ OF FEED 0.00

C

C."

a

C.

C

$C$ 


\section{$C \because$ \\ - Run muner anoszs700so}

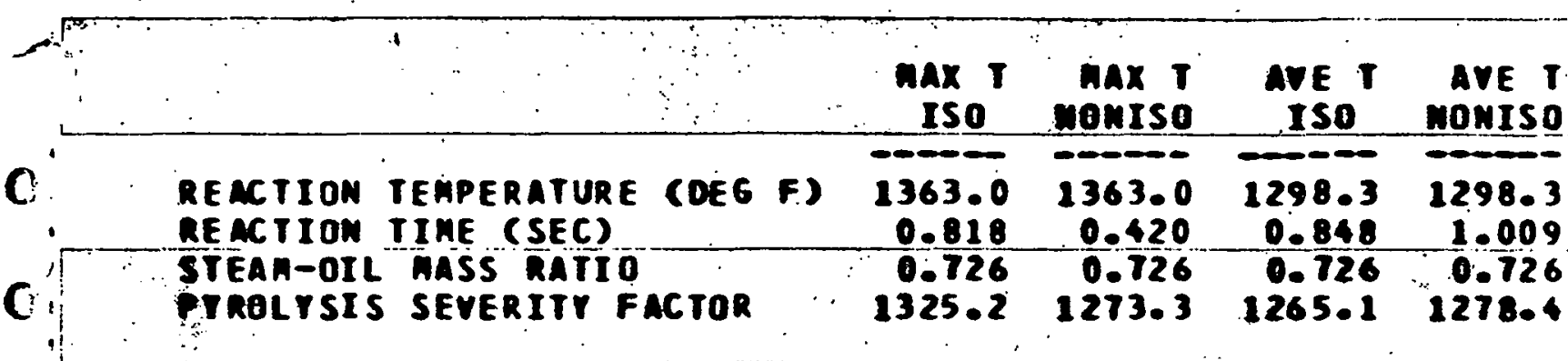

C

GASEOUS PRODUCTS

UT $\$$ OF FEED 49.33

SCF $\triangle B$ OF FEED 7.06

C

C:13 COMPONENT

MTOR OGEN

CARBDN MONOXIDE

METHANE

PROPANE

PROP TLENE

N-BUTANE

HTOROGEN SULFIDE

1-BUTENE

I SOBUTYLENE

TRANS-2-BUTENE

CIS-2-BUTE HE

1-3 BUTAOIENE

CARBON DIOXIDE

ETHYLENE

ETHA NE

ISOB UTANE

$\frac{\text { MOL 86AS }}{11.00} \cdot \frac{\text { UT GAS }}{0.84}$

UT $\&$ FEED

SCF F FEED

0.41

-

5.73

24.69

0.48

6.04

14.91

14.43

0.79

0.14

22.88

0.03

0.31

3.60

0.04

0.00

0.53

0.27

3.28

7.61

0.00

1.11

0.11

0.56

6.67

31. 70

4.02

0.19

33.49

0.00

4.55

0.00

7.36

0.39

11.29

0.15

0.02

0.78

0.40

1.74

0.03

1.02

0.01

3.75

0.00

0.00

0.25

0.55

0.00

0.28

3.29

0.04

0.02

0.23

0.09

0.01

16.52

2.24

2.25

0.00

0.28

LIQUID PRODUCTS

WT 7 OF FEED 50.67

C

SOLID PRODUCTS

UTY OF FEED 0.00

C.

WTS OF FEED 0.00 


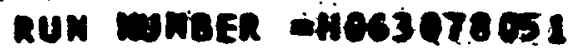

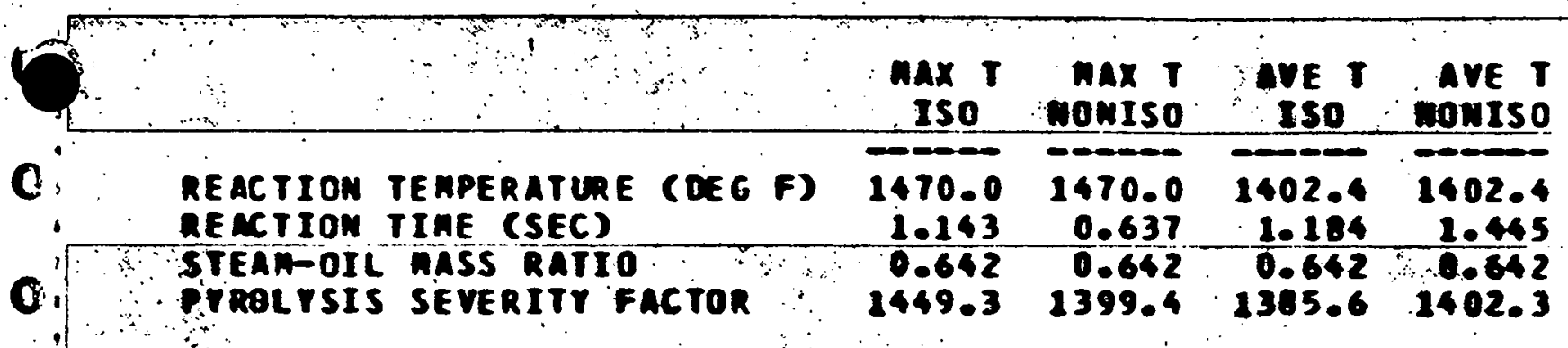

$C^{10}$ GASEOUS PRODUCTS
SCFRB OF. FEED 8.76

6i CONPONENT

$\begin{array}{ll}\text { G: } & \text { MYOROGEM } \\ \text { CARBON MONOXIOE }\end{array}$

METHANE

PROP ANE

PROP TLEME

N-BUTANE

MTOROGEN SULFIDE

1-BUTENE

ISOBUT TLENE

TRAN S-2-BUTENE

CIS-2-BUTENE

1-3 BUTADIENE

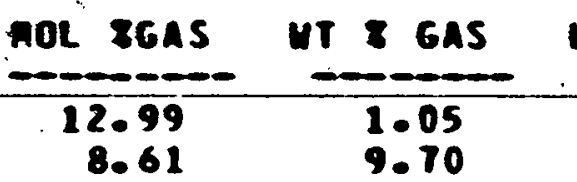

UT FEED

SCF I FEEO

CARBON DIOXIDE

ETHYLENE

ETHANE

ISOBUTANE

26.42

0.42

17.04

11.40

0.14

0.75

19.29

0.02

0.34

2.02

0.03

0.00

0.44

0.21

2.78

0.66

29.96

3.92

0.00

4.57

0.00

0.99

0.47

6.04

1.23

33.79

4.73

0.00

\begin{tabular}{c}
0.1 \\
\hline 0.60 \\
5.56 \\
9.77 \\
0.43 \\
11.06 \\
0.19 \\
0.02 \\
2.62 \\
0.00 \\
0.57 \\
0.27 \\
3.46 \\
0.70 \\
19.38 \\
2.71 \\
0.00
\end{tabular}

SCFIO FEED

C

LIQUIO PRODUCTS

WT $\$$ OF FEED 42.64

SOLIO PRODUCTS

UT OF FEED, 0.00

C

C::

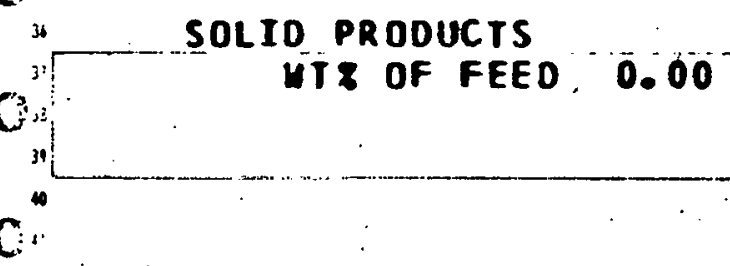


0

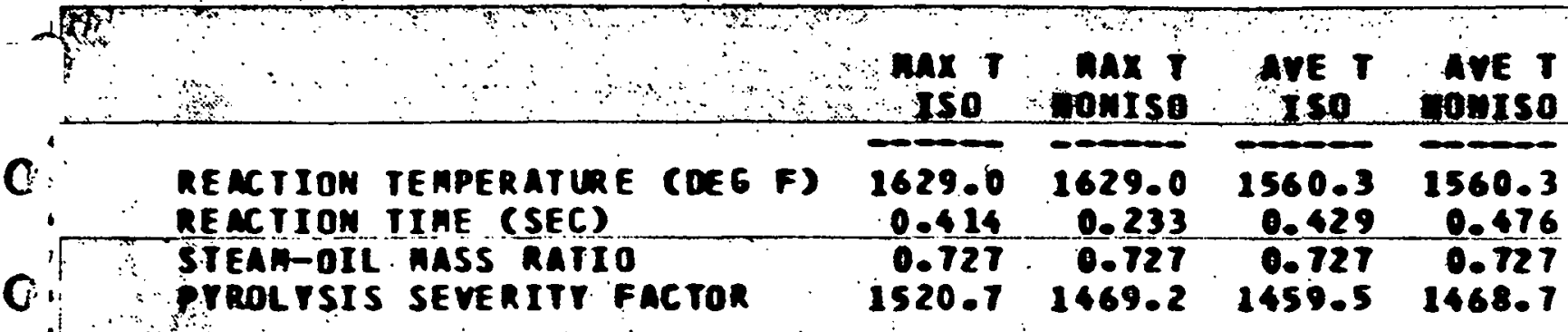

$C^{16}$ GASEOUS PRODUCTS

SCFRB OF FEED10.64

$c$

COAPONEAT

MYOROGEM

CARBON MOMOXIDE

METHANE

PROPANE

PROP YLEME

M-BuTAME

HYDROGEN SULFIDE

1-BUTENE

I SOBUT TLENE

TRANS-2-BUTENE

CIS-2-BUTENE

1-3 BUTAOIEME

CARBON DIOXIDE

ETHYLENE

ETHANE

ISOBUTANE
CIn
LIQUID PRODUCTS

MOL zGAS WT E GAS

$-$

13.59

3.70

34.72

0.14

6.71

0.18

0.00

0.44

0.00

0.41

0.04

1.99

0.23

35.7 .0

2. 15

0.00
1. 6AS

1.23

4.67

25.08

0.28

12.71

0.46

0.00

1.11

0.00

1.04

0.10

4.85

0.47

45.09

2.91

0.00
uT

1 FEED

$-2-$

0.77

2.90

15.60

0.18

T. 91

0.29

0.00

0.69

0.00

0.65

0.06

3.02

0.29

28.06

1.81

0.00
SCFII FEED -

1.45

0.39

3.69

0.02

0.71

0.02

0.00

0.05

0.00

0.04

0.00

0.21

0.02

3.80

0.23

0.00

${ }^{*}$ YT OF FEED 37.78

Cis

SOLID PRODUCTS

WIT OF FEED 0.00

sit

c

c.

C.

1

$\bar{C}$

$\bar{C}_{i b}$

(4)

(3) 


\section{RUN WUNBER =00Ti178001}

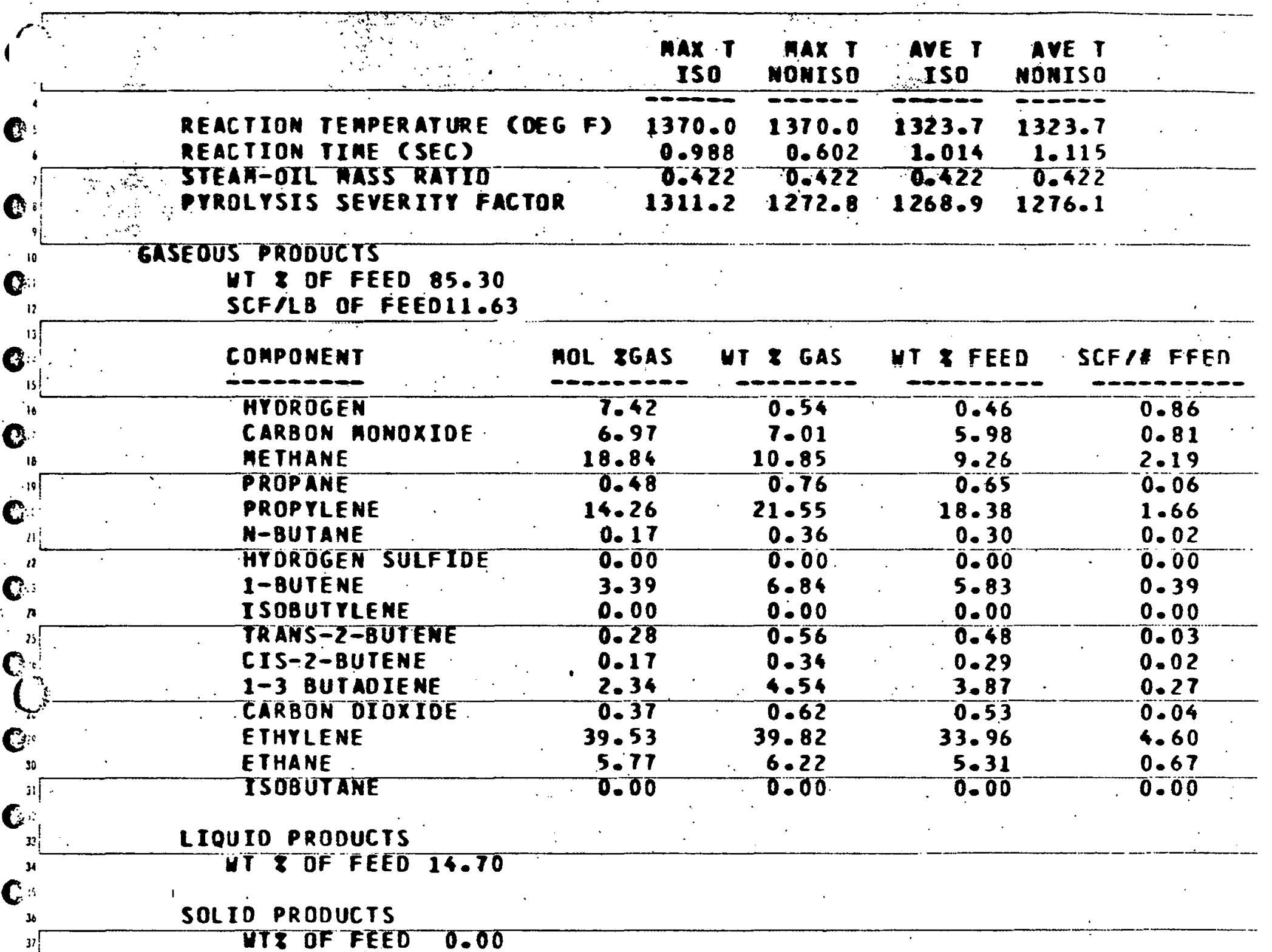

